EFFECTS OF OIL PRODUCTION ON WATER RESOURCES

IN THE KENTUCKY RIVER BASIN, KENTUCKY

by Ronald D. Evaldi, U.S. Geological Survey, and James A. Kipp, Kentucky Geological Survey

U.S. GEOLOGICAL SURVEY

Water-Resources Investigations Report 90-4191

Prepared in cooperation with the

KENTUCKY GEOLOGICAL SURVEY, UNIVERSITY OF KENTUCKY

Louisville, Kentucky 


\section{U.S. DEPARTMENT OF THE INTERIOR}

MANUEL LUJAN, JR., Secretary

U.S. GEOLOGICAL SURVEY

Dallas L. Peck, Director

For additional information write to:

District Chief

U.S. Geological Survey 2301 Bradley Avenue Louisville, Kentucky 40217
Copies of this report may be purchased from:

U.S. Geological Survey

Books and Open-File Reports Section Box 25425

Federal Center, Building 810 Denver, Colorado 80225 


\section{PREFACE}

In 1986, the Congress appropriated funds for the U.S. Geological Survey to test and refine concepts for a National Water-Quality Assessment (NAWQA) Program. The NAWQA Program is designed to address a wide range of waterquality issues that include chemical contamination, acidification, eutrophication, salinity, sedimentation, and sanitary quality. The long-term goals of the program are to:

1. Provide a nationally consistent description of current water-quality conditions for a large part of the Nation's water resources;

2. Define long-term trends (or lack of trends) in water quality; and

3. Identify, describe, and explain, as possible, the major factors that affect current conditions and trends in water quality.

This information will be provided to regulators, water managers, policy makers, and the public resulting in an improved scientific basis for evaluating the effectiveness of water-quality management programs and for predicting the likely effects of contemplated changes in land- and watermanagement practices.

At present (1990), the assessment program is in a pilot phase. Seven project areas--representing a diversity of hydrologic environments and waterquality conditions--were selected for the pilot program. The seven pilot project areas include four that focus primarily on surface water and three that focus primarily on ground water. The surface-water pilot project areas are the Yakima River basin in Washington; the lower Kansas River basin in Kansas and Nebraska; the Upper Illinois River basin in Illinois, Indiana, and Wisconsin; and the Kentucky River basin in Kentucky. The ground-water pilot project areas are the Carson basin in western Nevada and eastern California; the Central Oklahoma aquifer in Oklahoma; and the Delmarva Peninsula in Delaware, Maryland, and Virginia. 
The Kentucky River basin was selected as a pilot-study area because of its variety of land uses, including agriculture, oil and gas production, coal mining, forestry, and urbanization. In addition, most of the basin population derives its drinking-water supply from the Kentucky River or its tributaries. To achieve the National goals and objectives of the program, a plan of study has been adapted to the hydrologic and land-use conditions of the Kentucky River basin.

Specific objectives of the Kentucky River basin project are to:

1. Describe the occurrence and spatial distribution of a broad array of water-quality constituents;

2. Estimate loads of selected water-quality constituents at selected locations;

3. Provide information on the seasonal variation and the frequency of occurrence of selected water-quality constituents at selected locations;

4. Define long-term trends in concentrations and loads of selected constituents; and

5. Identify, describe, and explain, insofar as available information allows, the major factors that affect observed conditions and trends in surface-water quality.

A large amount of water-quality data have been collected in the United States by a diverse group of organizations for many different purposes. One of the first activities undertaken in the Kentucky River basin pilot project was a compilation, screening, and interpretation of available water-quality data for the study unit. Data from the oil and gas production areas of the basin were too limited to provide a comprehensive assessment of the effects of oil-production activities on surface-water quality. This report presents the results of a study, supported in part by the NAWQA Program, of the effects of oil and gas production on water resources in the Kentucky River basin. 


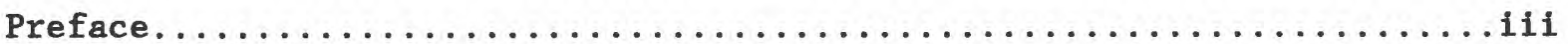

The Kentucky River Basin Project..................... iv

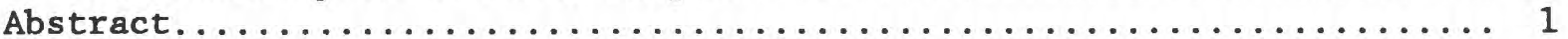

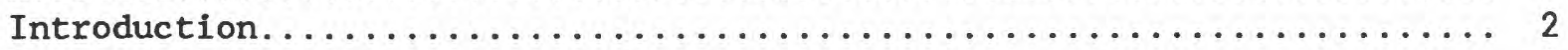

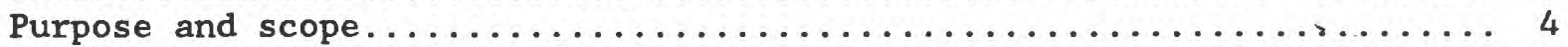

Description of the oil-production area..................... 5

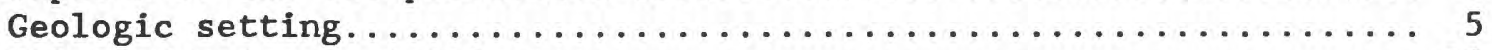

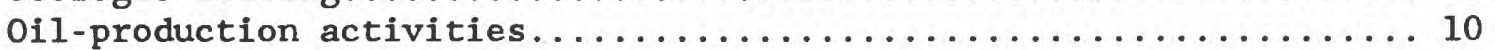

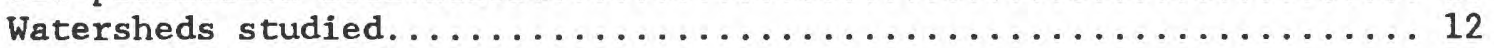

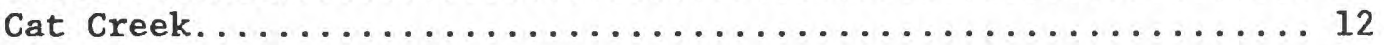

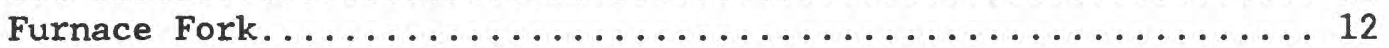

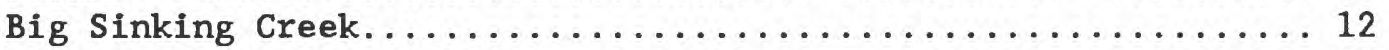

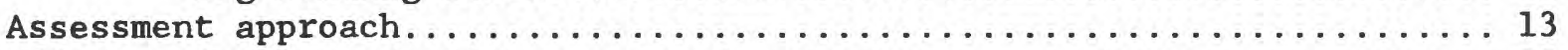

Effects of oil production on ground water.................. 15

Ground-water occurrence and character in unaffected watersheds..... 15

Ground-water occurrence and character in oil-production watersheds.. 16

Ground-water flow potential...................... 16

Ground-water quality.......................... 16

Effects of oil production on surface water.................. 20

Surface-water occurrence and character in unaffected watersheds.... 20

Surface-water occurrence and character in oil-production watersheds. 30

Extent of oil-production effects on surface-water quality........ 38

Relation of oil production to constituent transport............. 52

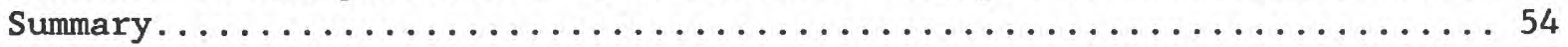

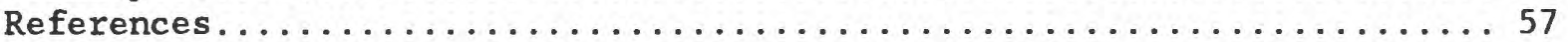

\section{ILLUSTRATIONS}

Figures 1-3. Maps showing:

1. Kentucky River basin.................. 3

2. Watersheds studied in the oil and gas production areas of the Kentucky River basin.......... 6

3. Generalized land cover and major mineral resource areas in the Kentucky River basin.......... 7

4. Graph of total monthly oil production in the

Kentucky River basin, $1982-88 \ldots \ldots \ldots \ldots \ldots \ldots \ldots \ldots$

5-6. Diagrams showing:

5. Monitoring wells in bedrock in the Furnace Fork basin showing water levels and dissolvedsolids concentrations on September 27, 1989..... 17

6. Summary of selected water-quality constituents from Big Sinking Creek, Furnace Fork, and Cat Creek, April 1987 to March 1989........... 22

7-8. Graphs showing:

7. Discharge of Big Sinking Creek, Furnace Fork, and Cat Creek, April 1987 to March 1989........ 28

8. Specific conductance of Big Sinking Creek, Furnace Fork, and Cat Creek, April 1987 to March 1989.... 29 
Figures 9-12. Graphs showing:

9. Duration statistics of daily specific conductance

in Big Sinking Creek, Furnace Fork, and

Cat Creek, and corresponding ionic composition

of water, April 1987 to March 1989............ 31

10. Duration statistics of bromide composition in

Big Sinking Creek, Furnace Fork, and Cat Creek,

April 1987 to March 1989.................. 32

11. Discharge and specific conductance in Furnace

Fork, March 15-20, and September 27

to October $3,1987 \ldots \ldots \ldots \ldots \ldots \ldots \ldots \ldots \ldots . \ldots . \ldots 39$

12. Monthly bromide load of Big Sinking Creek, Furnace Fork, and Cat Creek, April 1987

to March $1989 . . \ldots \ldots \ldots \ldots \ldots \ldots \ldots . . . \ldots \ldots$

13-16. Maps showing:

13. Dissolved barium concentrations at surface water synoptic sampling sites in the Kentucky River basin, August $24-28,1987 \ldots \ldots \ldots \ldots \ldots \ldots \ldots \ldots 42$

14. Dissolved bromide concentrations at surface water synoptic sampling sites in the Kentucky River basin, August 24-28, 1987...............43

15. Dissolved chloride concentrations at surface water synoptic sampling sites in the Kentucky River

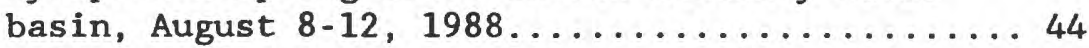

16. Dissolved sodium concentrations at surface water synoptic sampling sites in the Kentucky River basin, August $8-12,1988 \ldots \ldots \ldots \ldots \ldots \ldots \ldots \ldots 4$

17-19. Graphs showing:

17. Dissolved barium, bromide, and chloride concentrations in the main stem of the Kentucky River, August $24-28,1987$, and August $8-12,1988 \ldots \ldots 46$

18. Monthly dissolved bromide and chloride load of the Kentucky River at Lock 10, January 1982 to March $1989 \ldots \ldots \ldots \ldots \ldots \ldots \ldots \ldots$

19. Relation of oil production in the Kentucky River basin to the dissolved bromide load in the Kentucky River at Lock 10,

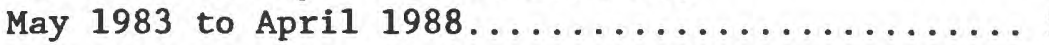




\section{TABLES}

Table 1. Description of physical and hydrologic characteristics

Page of geologic formations in the Kentucky River basin, Kentucky.

2. Water quality of selected wells, springs, and separator discharges in the Big Sinking Creek and Furnace Fork watersheds during September 1988........ 19

3. Composition of water from selected we1ls, springs, and separator discharges in the Kentucky River basin, expressed as a percentage of total anion or cation

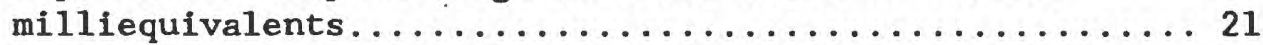

4. Regression equation variables describing the relation between specific conductance and selected water-quality constituents in Big Sinking Creek, Furnace Fork, and Cat Creek.

5. Average annual transport of selected water-quality constituents in Big Sinking Creek, Furnace Fork, and Cat Creek, April 1, 1987 to March 31, 1989.......... 34

6. Concentration and load estimates of bromide and chloride in the Kentucky River at Lock 10, January 1982 to April 1989. 


\section{CONVERSION FACTORS}

For those readers who prefer to use metric (International System) units rather than inch-pound units, the following conversion factors may be used:

\section{Multiply inch-pound units}

acre

barrel (bb1), petroleum

inch (in.)

foot ( $f t$ )

mile (mi)

pound (1b)

ton per square mile $\left(\right.$ ton $/ \mathrm{mi}^{2}$ )

cubic foot per second $\left(\mathrm{ft}^{3} / \mathrm{s}\right)$

gallon (gal)

gallon per minute (gal/min)

gallon per day (gal/d)

million gallons per day (Mgal/d)

micromho ( $\mu$ mho)

pound per square inch $\left(1 \mathrm{~b} / \mathrm{in}^{2}\right)$
By

\author{
0.4047 \\ 0.1590 \\ 25.40 \\ 0.3048 \\ 1.609 \\ 0.4536 \\ 350.3
}

28.32

3.785

0.06308

3.785

0.04381

1.000

0.07031

\section{To obtain metric units}

hectare (ha)

cubic meter $\left(\mathrm{m}^{3}\right)$

millimeter ( $\mathrm{mm}$ )

meter (m)

kilometer $(\mathrm{km})$

kilogram $(\mathrm{kg})$

kilogram per square kilometer $\left(\mathrm{kg} / \mathrm{km}^{2}\right)$

cubic decimeter per second $\left(\mathrm{dm}^{3} / \mathrm{s}\right)$

liter (L)

liter per second (L/s)

liter per day (L/d)

cubic meter per second $\left(\mathrm{m}^{3} / \mathrm{s}\right)$

microsiemens ( $\mu \mathrm{S})$

kilogram per square centimeter $\left(\mathrm{kg} / \mathrm{cm}^{2}\right)$

Temperature in degrees Fahrenheit $\left({ }^{\circ} \mathrm{F}\right)$ can be converted to degrees Celsius $\left({ }^{\circ} \mathrm{C}\right)$ as follows:

$$
{ }^{\circ} \mathrm{C}=\left({ }^{\circ} \mathrm{F}-32\right) / 1.8
$$

Sea level: In this report "sea level" refers to the National Geodetic Vertical Datum of 1929 (NGVD of 1929)--a geodetic datum derived from a general adjustment of the first-order level nets of the United States and Canada, formerly called Sea Level Datum of 1929. 
EFFECTS OF OIL PRODUCTION ON WATER RESOURCES

IN THE KENTUCKY RIVER BASIN, KENTUCKY

by Ronald D. Evaldi, U.S. Geological Survey, and James A. Kipp, Kentucky Geologica1 Survey

\begin{abstract}
As part of a comprehensive study of water quality in the Kentucky River basin, an area of intense oil-production activity was investigated. An average of about 10 barrels of saline water is produced with each barrel of oil, and is reinjected to enhance oil recovery or discharged to surface waters. Although the oil-production activities are suspected of affecting water quality in the basins, the extent and magnitude of the effects have not been adequately defined. This study was conducted to describe the chemical character of ground and surface water in oil fields of the Kentucky River basin, and to assess the effects of drainage from these fields on receiving waters. Three watersheds were studied. Big Sinking Creek and Furnace Fork have producing oil wells. The third watershed, Cat Creek, was used as the study control. The Cat Creek watershed is adjacent to Furnace Fork and is underlain by similar geology, but has not had any oil production activities.
\end{abstract}

Ground-water samples obtained in the oil-production watersheds indicated that shallow ground water in valley alluvium was probably not widely affected by oil-production activities, that secondary recovery of oil by water flooding had decreased the dissolved-solids concentration of water in the oil-bearing formations but not in the overlying formations, and that the character of water in a shallow bedrock formation may reflect mixing of fresh water from the overlying alluvium and saline water from deeper units. Water from springs and wells in the alluvium, and from shallow bedrock wells was usually of the calcium-bicarbonate type; and water from deep wells, including oil-production water, was of the sodium-chloride type.

Specific conductance and discharge of streams draining the three watersheds studied were continuously monitored April 1987 to March 1989, and water samples were collected monthly for comprehensive water-quality analysis. Surface water from Cat Creek was generally a calcium-bicarbonate type. Bromide concentrations ranged from less than 0.01 milligrams per liter to 1.4 milligrams per liter, and chloride concentrations ranged from 0.2 to 213 milligrams per liter. The annual yield of bromide during this period was 0.08 tons per square mile and the yield of chloride was 19 tons per square mile. Bromide concentrations greater than 40 milligrams per liter and chloride concentrations more than 4,000 milligrams per liter occurred in Big Sinking Creek during the April 1987 through March 1989 period. Surface water from Big Sinking Creek was a sodium-chloride type and the annual yields of bromide, chloride, sodium, and strontium were about 10 times greater than from Cat Creek. The greatest constituent transport usually occurred during flushing of the watersheds by initial high-flow events following the low-flow summer through fall season. Comparatively little constituent transport occurred during low-flow periods. 
Synoptic sampling of surface waters throughout the Kentucky River basin helped to describe the extent of oil field drainage effects on water quality. The areal extent of oil-brine discharges included tributary streams of the North and South Forks of the Kentucky River, the headwaters of Millers Creek, and many tributary streams of the Middle and South Forks of the Red River. Increases in concentrations of barium, bromide, chloride, sodium, and strontium in the main stem of the Kentucky River downstream of river mile 270 are attributed to drainage from oil-production watersheds.

The largest concentrations of chloride and bromide in the Kentucky River at Lock 10 (river mile 176) typically occur in the fall during the first period of significantly increased runoff following the dry late-summer months. This period corresponds in general to the time of first flushing of accumulated salts from the watersheds studied. Monthly chloride and bromide transport in the Kentucky River at Lock 10 had a similar pattern as that of the Big Sinking Creek, Furnace Fork, and Cat Creek watersheds. Bromide loads in the Kentucky River at Lock 10 appear to be positively correlated with oil production levels in the basin, but additional information is needed on oil and gas production activities to further refine and quantify this relation.

\section{INTRODUCTION}

The Kentucky River basin (fig. 1) is the most densely populated river basin in Kentucky and is projected to be the area of most population and industrial growth in the future. As of 1980, approximately 632,000 people, or about 18 percent of the total State population, resided in the basin (U.S. Department of Commerce, 1982). Protection of the quality of water draining to the Kentucky River is vital because the river and its tributaries are used extensively for public and industrial water supply, recreation, propagation of fish and wildlife, and municipal and industrial waste discharge and assimilation. Water from the Kentucky River, its tributaries, and reservoirs provide more than 95 percent of the public water supplied in the basin (Sholar, 1988; Sholar and Lee, 1988). Impairment of the water quality of the Kentucky River could result in substantial socioeconomic damage.

0il-brine pollution in Kentucky streams has been documented in several Kentucky biannual reports to Congress (Kentucky Natural Resources and Environmental Protection Cabinet, 1984, 1986, and 1988). Water-quality constituents commonly found in brines include bromide and chloride. No state or Federal water-quality criteria exists for bromide, but it is of particular concern because of its role in the formation of carcinogenic trihalomethane (THM) compounds during drinking water treatment. The Kentucky criteria for protection of warm water aquatic habitats for chloride is $600 \mathrm{mg} / \mathrm{L}$ (milligram per liter). Because many treatment processes do not remove chloride, Kentucky's drinking water supply criteria is $250 \mathrm{mg} / \mathrm{L}$. 


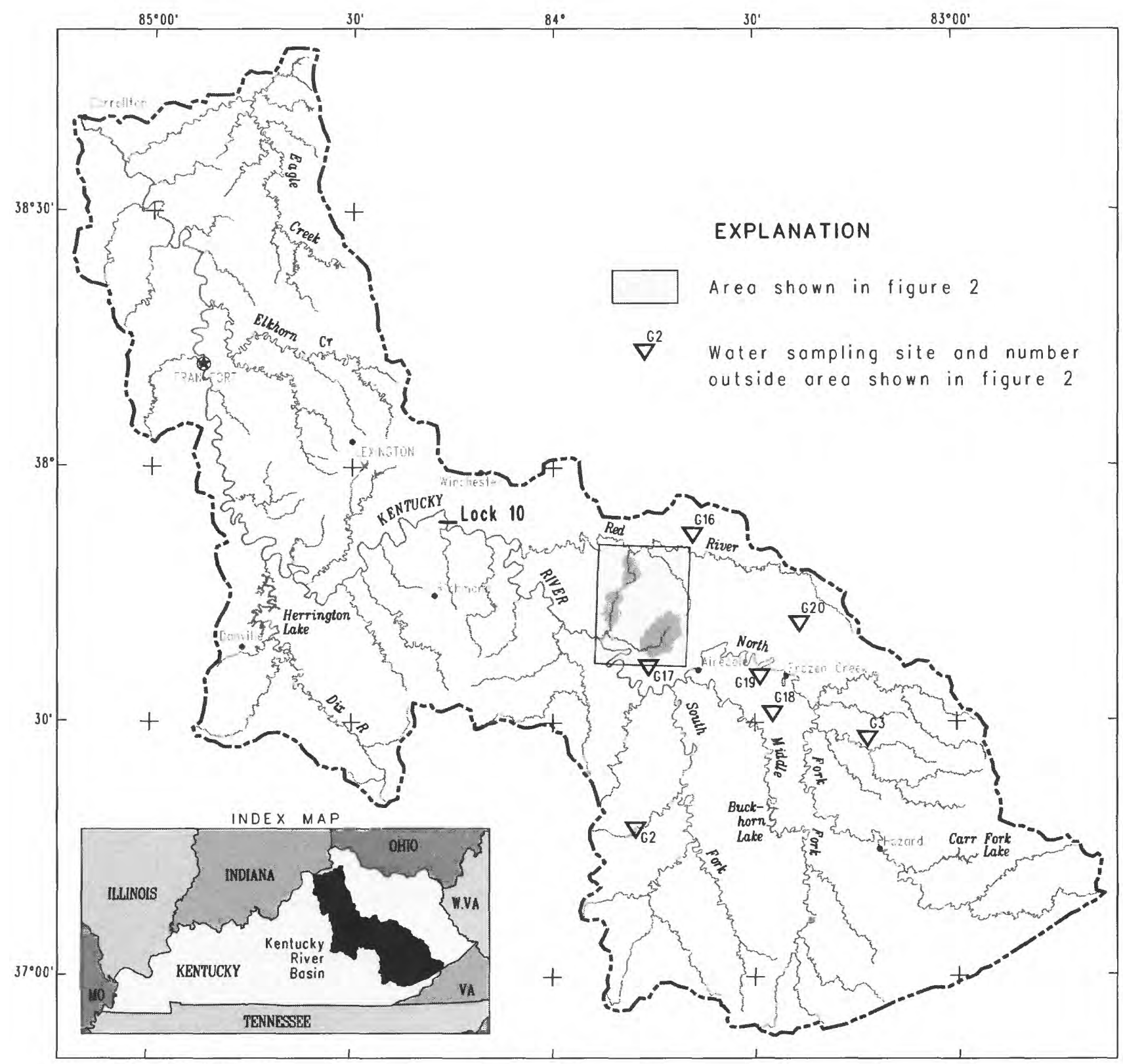

Bose from U.S. Geologicol Survey

Digilal line grophs from 1:100,000 maps

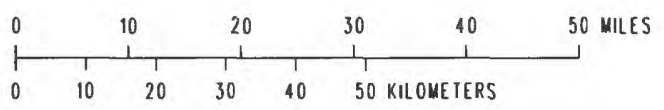

Figure 1.--Kentucky River bosin. 
Studies of several streams in the Kentucky River basin have attributed degradation of aquatic biologic habitats and resultant decrease in species diversity to the discharge of brines from oil fields. For example, Bradfield and Porter (1990) noted that aquatic communities in streams receiving brines from oil fields are dominated by taxa tolerant of elevated salinity concentrations. The brines also were reported to have caused problems with public drinking water supplies. However, water-quality data from the oilproduction areas of the basin were too limited to describe the character or source of these brines, or their spatial and temporal effects on ground-water and surface-water resources.

In order to address the concern that oil-brine discharges may be adversely affecting the quality of water in the Kentucky River basin, the U.S. Geological Survey (USGS) in cooperation with Kentucky Geological Survey (KGS) initiated a study in 1987 to compile data for assessment of this concern. The use of industry or firm names in this report is for location purposes only, and does not impute responsibility for any present or potential effects on the natural resources.

\section{PURPOSE AND SCOPE}

This report summarizes the results of an investigation of the effects of oil production on surface-water and ground-water resources of the Kentucky River basin during the period March 1987 through April 1989. The report includes information on the areal extent of waters affected by oil-production in the Kentucky River basin. The transport of selected water-quality constituents from two oil-production watersheds are contrasted with that in an adjacent non-production watershed. Transport of selected constituents in the Kentucky River are compared with their transport from the oil-production watersheds. A relation between constituent transport in the Kentucky River and oil-production levels of the basin is described. Specifically, the purposes of the report are to describe:

1. The chemical character of ground and surface water draining oil fields in the Kentucky River basin;

2. The mass transport of selected chemical constituents;

3. The effects of drainage from the oil-production areas on downstream water quality; and

4. The relation of oil production to constituent concentrations and mass transport in the Kentucky River.

Constituent concentration and transport information obtained during this study will be of use to agencies responsible for the management of water resources, including those directed at wildlife and fisheries preservation, drinking water protection, and wastewater discharge regulation. Information from this study will be particularly useful to water-system operators for developing pumping strategies to avoid drinking water quality concerns. 
The oil-production area selected for investigation is in Esti11, Lee, and Powel1 Counties of southeastern Kentucky (figs. 1 and 2). This area is almost entirely within the Appalachian Plateau physiographic province near the western edge of the Eastern Coal Field region (Fenneman, 1938). The Appalachian Plateau is an intricately dissected upland characterized by narrow crooked valleys separated by irregular narrow steep-sided ridges. Elevation of the study area ranges from 640 to 1,400 feet above sea level. Production of oil is a major activity in the study area (fig. 3). Gas occurs in the oil fields, but it is not produced commercially. Thus, water quality effects discussed in this report represent those associated with brines that are produced with oil.

\section{Geologic Setting}

The stratigraphy of the study area consists of shales, siltstones, sandstones, dolomites, and limestones (table 1). Rocks at the surface are oldest in the western part of the study area, and they become progressively younger to the east. The valleys and ridge slopes of the Furnace Fork and Cat Creek basins are underlain by rocks of Mississippian age, and the ridges are capped by rocks of Pennsylvanian age. The Big Sinking Creek basin is underlain by rocks of Pennsylvanian age except for the valley bottom near the downstream end of the basin where rocks of Mississippian age crop out.

Karst features have developed in the form of numerous sinkholes, sinking streams, caves, and valleys on several ridges where rocks of Pennsylvanian age have eroded and left carbonate rocks of Mississippian age exposed at the surface. Surface-water/ground-water interaction in these karst areas can be significant. Big Sinking Creek derives its name from disappearing reaches along its course, and in the Big Sinking Creek watershed there are reportedly more than 100 cave entrances and other solution features developed in the Newman Limestone. The karst underground drainage network of the study area is probably quite extensive and may even cross surface drainage divides and provide routes for cross-contamination of watersheds (U.S. Environmental Protection Agency, 1983).

The oil-producing units in the area occur in what is commonly known as the "Corniferous zone" (Robinson, 1927). This is a drillers' term for a sequence of dolostone, limestone, and shale occurring about 450 to 700 feet below the base of the Newman Limestone (table 1). The entire "Corniferous zone" is as much as 100 feet thick, but the individual oil-production zones range from 6 to 20 feet in thickness (Stack, 1965). The "Corniferous zone" corresponds to the Middle Devonian Boyle Dolomite and the Middle Silurian Bisher (?) Limestone (Freeman, 1951; McGrain, 1958). 


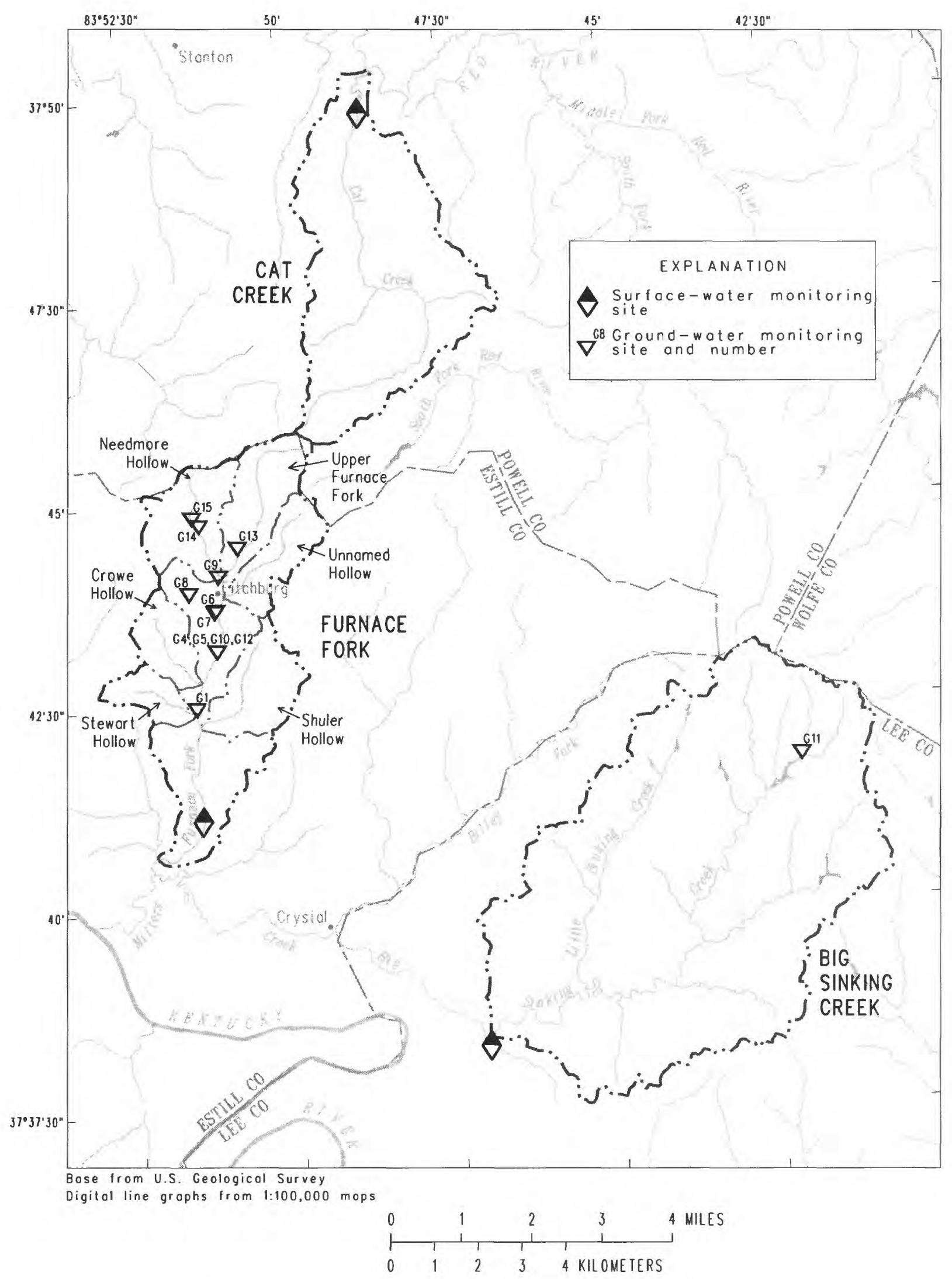

Figure 2.--Watersheds studied in the oil and gas production areas of the Kentucky River bosin. 


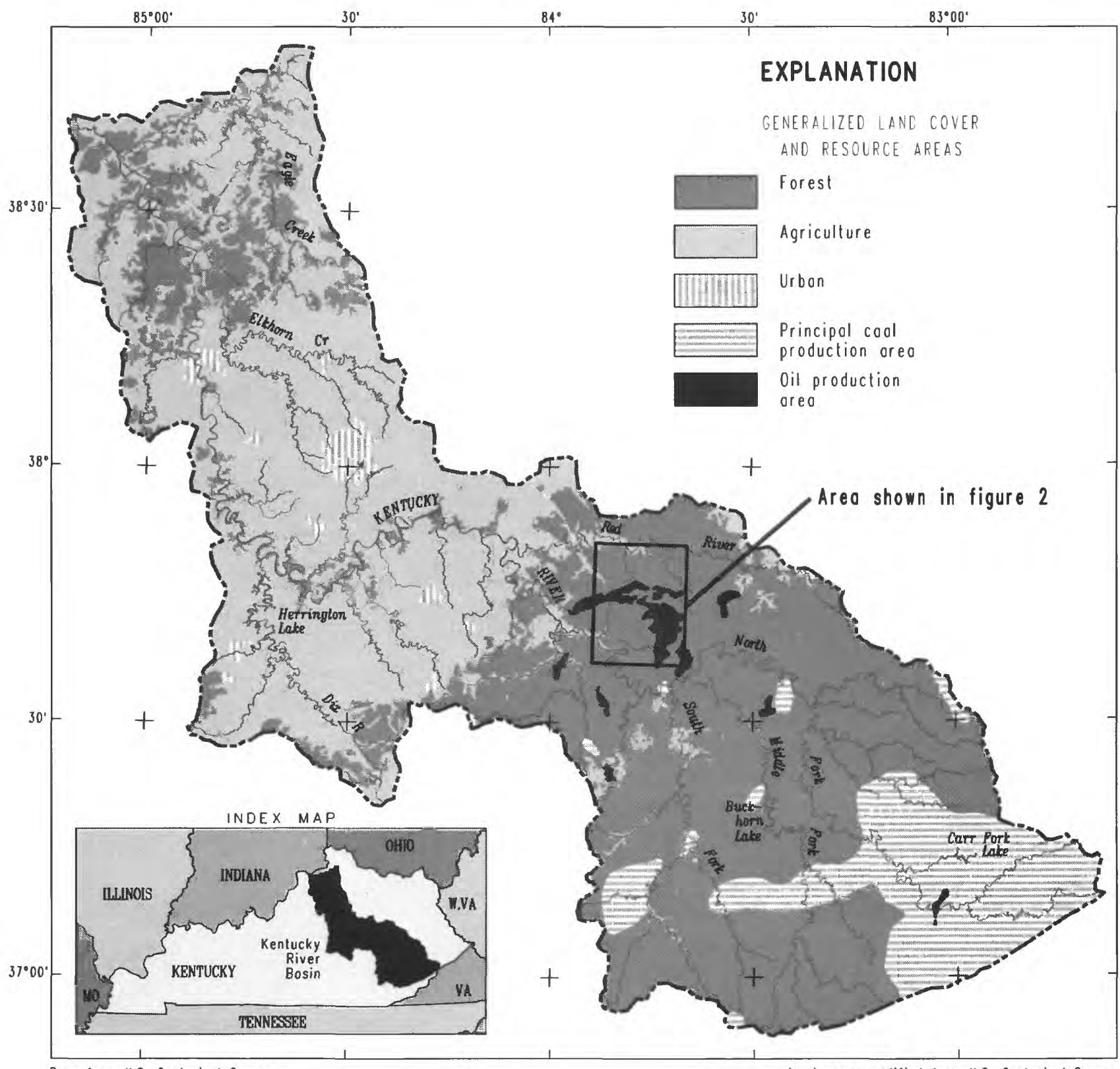

Bose from U.S. Geologicol Survey

Digilol line grophs from $1: 100,000$ mops

Land cover modified from U.S. Geologicol Survey Digitol dolo from 1:250,000 mops Cool production madified from Johnson ond others (1962) Oil produclion modilied Irom Wilson and Sulton (1973)

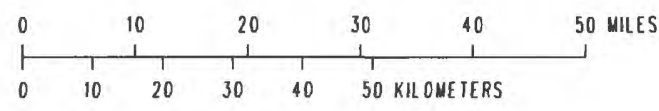

Figure 3.--Generalized land cover and major mineral resource oreas in the Kentucky River bosin. 
Table 1.--Descriptions of physical and hydrologic characteristics of formations in the Kentucky River basin, Kentucky

\begin{tabular}{|c|c|c|c|c|c|c|}
\hline System & Series & \multicolumn{2}{|c|}{$\begin{array}{l}\text { Formation } \\
\text { and member }\end{array}$} & \multicolumn{2}{|c|}{$\begin{array}{l}\text { Thickness, } \\
\text { in feet }\end{array}$} & $\begin{array}{c}\text { Hydrologic } \\
\text { characteristics }\end{array}$ \\
\hline 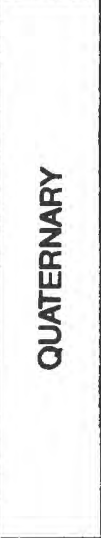 & 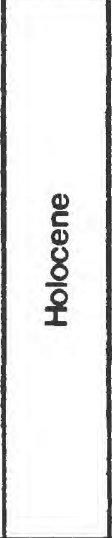 & \multicolumn{2}{|c|}{ Alluvium } & $\begin{array}{l}0 \\
\text { to } \\
50\end{array}$ & $\begin{array}{l}\text { Silt, clay, sand, and gravel } \\
\text { deposits occurring in valleys } \\
\text { of the principal streams and along } \\
\text { the Kentucky and Red Rivers. } \\
\text { Predominantly silt and silty clay, } \\
\text { but can be sandy and locally contains } \\
\text { lenses of quartzose sand. Gravel } \\
\text { consists of subrounded to well- } \\
\text { rounded fragments of siltstone from } \\
\text { the Borden Formation, angular to } \\
\text { rounded fragments of chert from the } \\
\text { Newman Limestone, and well-rounded } \\
\text { pebbles of quartz from the Corbin } \\
\text { Sandstone Member of the Lee } \\
\text { Formation. The alluvium may be up to } \\
\text { 50 feet thick along the Kentucky } \\
\text { River but becomes much thinner and } \\
\text { laterally grades into colluvium in } \\
\text { the upper portions of the tributary } \\
\text { basins. }\end{array}$ & $\begin{array}{l}\text { Yields more than } 500 \text { gallons per day } \\
\text { along the Red River, but not much } \\
\text { elsewhere. A high in the freshwater } \\
\text { saline water interface generally } \\
\text { coincides with the Irvine-Paint } \\
\text { Creek uplift in Estill, Lee, and } \\
\text { Wolfe Counties. Water with } \\
\text { dissolved solids concentrations } \\
\text { greater than } 1,000 \text { milligrams per } \\
\text { liter can occur at or near land } \\
\text { surface in most valleys (Hopkins, } \\
\text { 1966). However, shallow hand dug } \\
\text { wells are commonly used for water } \\
\text { supply, and water with dissolved- } \\
\text { solids concentration of less than } \\
\text { 1,000 milligrams per liter occurs in } \\
\text { many places. }\end{array}$ \\
\hline \multirow{3}{*}{ 紊 } & \multirow{3}{*}{ 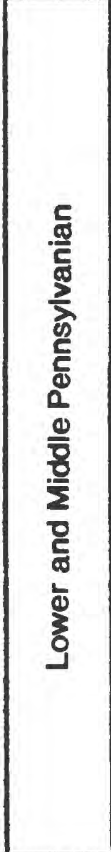 } & \multirow{3}{*}{ 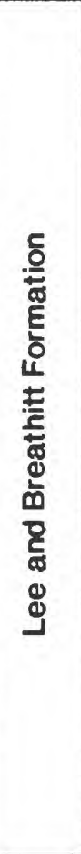 } & $\begin{array}{l}\text { upper } \\
\text { member } \\
\text { of } \\
\text { Breathitt } \\
\text { Formation }\end{array}$ & $\begin{array}{c}40 \\
\text { to } \\
200+\end{array}$ & $\begin{array}{l}\text { Shale, silty shale, siltstone, and } \\
\text { minor sandstone. Shale contains } \\
\text { concretions of siderite and limonite. } \\
\text { Silty shale and siltstone } \\
\text { interlaminated with shale. Sandstone } \\
\text { fine grained, in part micaceous; } \\
\text { occurs mainly as a few widely spaced } \\
\text { lenses in lower } 60 \text { feet of unit. } \\
\text { Zachariah coal bed, } 20 \text { to } 50 \text { feet } \\
\text { above the base of the unit in } \\
\text { Zachariah quadrangle is common } \\
\text { banded, pyritic in part. }\end{array}$ & \multirow{3}{*}{$\begin{array}{l}\text { Wells from Pennsylvanian rocks } \\
\text { (Breathitt and Lee Formations) } \\
\text { generally supply from } 100 \text { to } 500 \\
\text { gallons per day, but supplies are } \\
\text { less on hillsides and narrow } \\
\text { ridgetops. } \\
\text { Dissolved solids concentration of } \\
\text { water from } 16 \text { wells in Pennsylvanian } \\
\text { rocks in the Kentucky River basin } \\
\text { ranged from } 46 \text { to 52,000 milligrams } \\
\text { per liter. Median specific } \\
\text { conductance of water from } 136 \text { wells } \\
\text { in the basin was } 336 \text { microsiemens } \\
\text { per centimeter. Salty water } \\
\text { commonly occurs in wells extending } \\
\text { more than } 100 \text { feet below the valley } \\
\text { bottoms (Price and others, 1962b; } \\
\text { Hall and Palmquist, 1960). }\end{array}$} \\
\hline & & & $\begin{array}{l}\text { Corbin } \\
\text { Sandstone } \\
\text { member } \\
\text { of } \\
\text { Lee } \\
\text { Formation }\end{array}$ & $\begin{array}{c}50 \\
\text { to } \\
250\end{array}$ & $\begin{array}{l}\text { Sandstone locally conglomeratic with } \\
\text { pebbles as much as } 1 \text { inch across, } \\
\text { pebbles subrounded to rounded and } \\
\text { composed primarily of quartz with } \\
\text { minor amounts of chert, crossbedded, } \\
\text { mostly in steep planar and trough } \\
\text { sets. In Zachariah quadrangle can } \\
\text { occur as } 2 \text { bodies separated by a } \\
\text { tongue of shale as much as } 60 \text { feet } \\
\text { thick. }\end{array}$ & \\
\hline & & & $\begin{array}{l}\text { lower } \\
\text { tongue } \\
\text { of } \\
\text { Breathitt } \\
\text { Formation }\end{array}$ & $\begin{array}{r}0 \\
\text { to } \\
250\end{array}$ & $\begin{array}{l}\text { Shale, siltstone, sandstone, and } \\
\text { coal. Shale commonly limonite } \\
\text { stained. Sandstone fine to medium } \\
\text { grained; chiefly tabular, locally as } \\
\text { much as } 50 \text { feet thick. Coal beds as } \\
\text { much as } 2 \text { feet thick, discontinuous. } \\
\text { Underclay generally less than } 1 \text { foot } \\
\text { thick. }\end{array}$ & \\
\hline \multirow{2}{*}{ 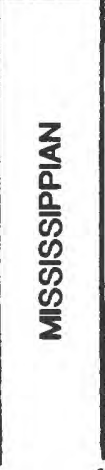 } & \multirow{2}{*}{$\begin{array}{l}\text { ఖ } \\
\frac{0}{8}\end{array}$} & \multicolumn{2}{|c|}{$\begin{array}{l}\text { Pennington } \\
\text { Formation }\end{array}$} & $\begin{array}{r}0 \\
\text { to } \\
45\end{array}$ & $\begin{array}{l}\text { Shale, limestone, dolostone, and } \\
\text { sandstone. Shale locally calcareous. } \\
\text { Limestone, fossil fragmental, fine to } \\
\text { coarse grained calcarenite. } \\
\text { Dolostone occurs as tabular beds } 1 \\
\text { inch to } 1 \text { foot thick in shale. } \\
\text { Sandstone very fine to fine grained } \\
\text { in nodular beds (Unit not recognized } \\
\text { in Cobhill quadrangle) }\end{array}$ & \multirow{2}{*}{$\begin{array}{l}\text { Pennington Formation yields almost } \\
\text { no water. } \\
\text { Ground-water yields from the Newman } \\
\text { Limestone can exceed } 50 \text { gallons per } \\
\text { minute where large solution cavities } \\
\text { are penetrated. The Newman produces } \\
\text { only minor quantities of water where } \\
\text { it is capped by Pennsylvanian rocks. }\end{array}$} \\
\hline & & 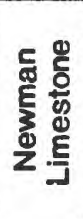 & $\begin{array}{l}\text { upper } \\
\text { member }\end{array}$ & $\begin{array}{r}0 \\
\text { to } \\
120\end{array}$ & $\begin{array}{l}\text { Limestone and shale. Limestone } \\
\text { variable in nature, fossil- } \\
\text { fragmental, oolitic, pelletal } \\
\text { calcarenite, becomes finer near base } \\
\text { (clacisiltite or microsparite). } \\
\text { Shale most common in upper one-half } \\
\text { of unit. }\end{array}$ & \\
\hline
\end{tabular}


Table 1.--Descriptions of physical and hydrologic characteristics of formations in the Kentucky River basin, Kentucky--Continued

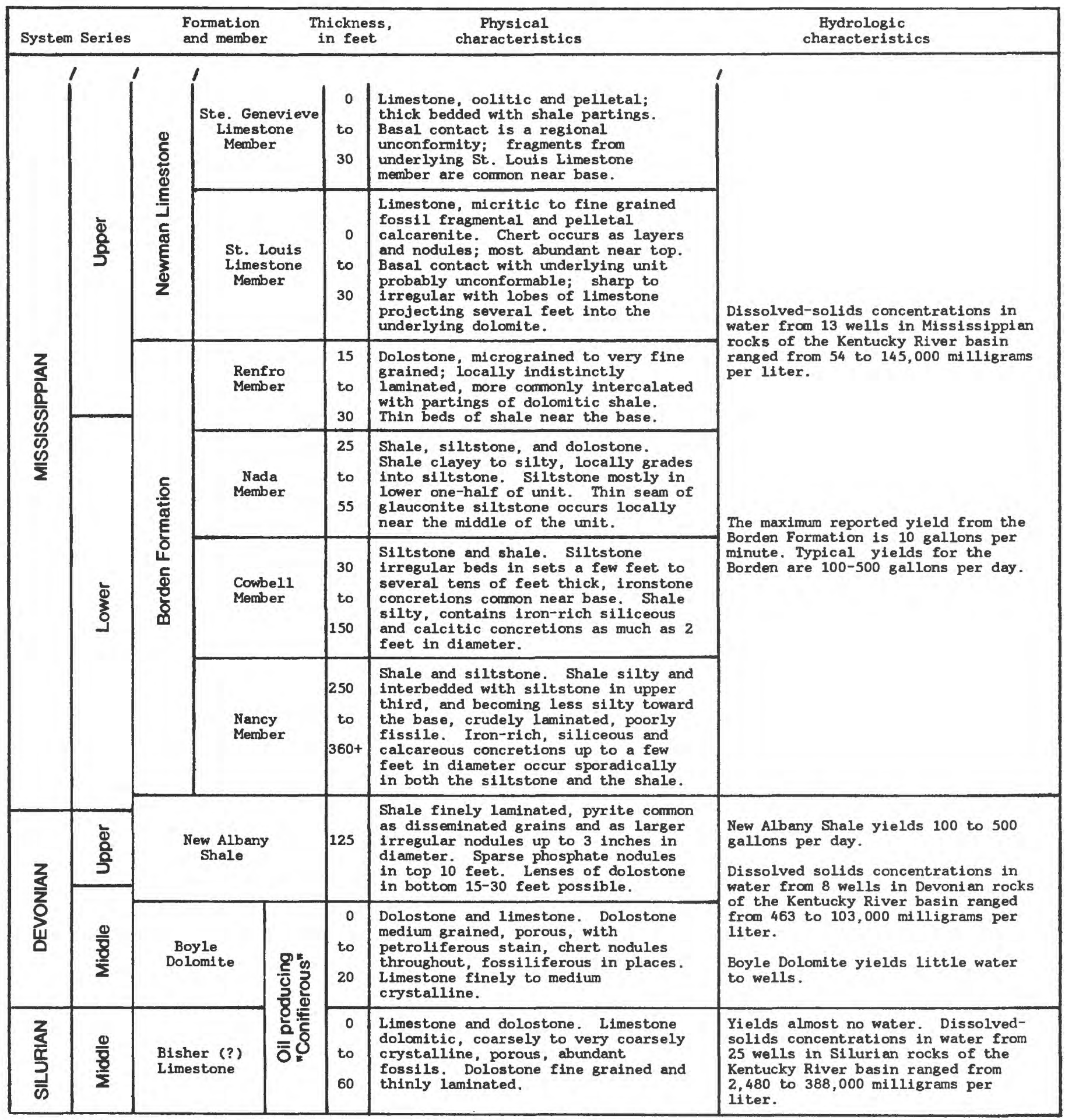

Geology summarized from geologic quadrangles GQ-1347, Cobhill (Haney, 1976); GQ-1182, Stanton (Weir, 1974); GQ-1285, Irvine (Hoge and others, 1976); and GQ-1452, Zachariah (Black, 1978): and from Miscellaneous Field Studies Map-1291 (McDowe11, 1981). Formation yields summarized from Hall and Palmquist (1960). 


\section{Oil-Production Activities}

Monthly oil-production data in counties of the Kentucky River basin were available from the Kentucky Geological Survey Petroleum and Stratigraphy Section Data Service. Based on these data, annual oil production in counties of the Kentucky River basin averaged 1.6 million barrels from 1982 through 1987. Peak monthly production during this period was about 190,000 barrels in October 1985 (fig. 4). Oil-production data were not available for individual fields or producers.

Most of the oil wells in eastern Kentucky are stripper wells, that produce less than 10 barrels of oil per day (U.S. Environmental Protection Agency, 1983). Saline water is produced along with the oil. Although the dissolved-solids concentration of this water is often less than $35,000 \mathrm{mg} / \mathrm{L}$, it is commonly referred to as brine. Kentucky Division of Water's Oil and Wet Gas Well Registry Lease files indicate that the volume of brine produced per barrel of oil can range from less than 1 to greater than 300 barrels. An average of 10 barrels of brine for each barrel of oil is considered a good approximation (U.S. Environmental Protection Agency, 1983).

Oil and brine pumped from the production wells are piped into separators where the oil floats to the top of the tank. After a sufficient amount of oil accumulates it flows from the separator to a storage tank. Brine is commonly discharged from an inclined pipe positioned below the bottom of the floating oil. Historically, the brine was discharged to holding ponds where heavy particles could sink and the lighter oil could float to the top of the pond. Brine was discharged from the pond to surface streams through an inclined pipe inserted beneath the brine/oil interface in the pond. Many producers discharged brine directly from separators to adjacent streams without storing in an intermediate holding pond.

The state of Kentucky currently requires registration of production facilities, including tank batteries and separators. Disposal of brine is also regulated. Injection of freshwater or a mixture of freshwater and production brine into the oil-production formations at pressures from 500 to $1,000 \mathrm{lb} / \mathrm{in}^{2}$ (pound per square inch) for enhanced oil recovery is a common practice. Reinjection is allowed by permit from the U.S. Environmental Protection Agency (EPA) under the Underground Injection Control Program. Direct discharge of brine to surface streams is allowed with a Kentucky Pollution Discharge Elimination System Permit from the Kentucky Division of Water. General permit requirements limit average daily in-stream chloride concentrations to $600 \mathrm{mg} / \mathrm{L}$, and instantaneous maximum concentrations to $1,200 \mathrm{mg} / \mathrm{L}$. In addition, State regulations require that the permittee not discharge more than an assigned amount of chloride each day. The chloride discharge limits are set to maintain concentrations in receiving streams within State standards for protection of aquatic habitats $(600 \mathrm{mg} / \mathrm{L})$, or within drinking water standards $(250 \mathrm{mg} / \mathrm{L})$ if the receiving waters are used for that purpose. 


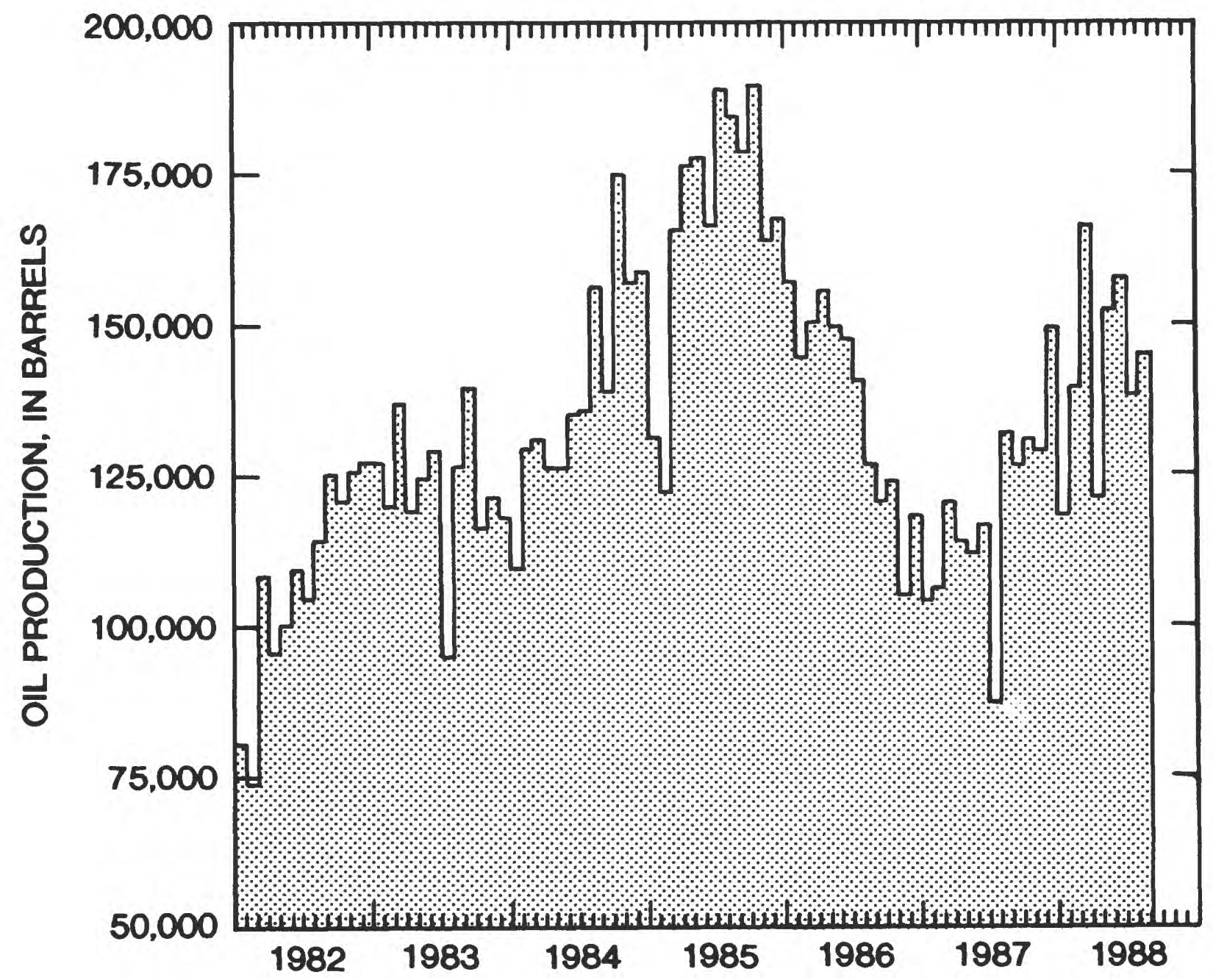

Figure 4.--Total monthly oil production in the Kentucky River basin, 1982-88. 


\title{
Watersheds Studied
}

\author{
Cat Creek
}

The Cat Creek watershed (fig. 2) is underlain by geologic strata similar to those in the Furnace Fork and Big Sinking Creek watersheds but no oil production was known to have occurred in the watershed prior to or during the study. The Cat Creek watershed is adjacent to the Furnace Fork watershed, but is tributary to the Red River. The Cat Creek gaging station was installed on the downstream side of a highway box culvert about 2.7 miles southeast of Stanton in Powell County (latitude $37^{\circ} 49^{\prime} 41^{\prime \prime}$, longitude $83^{\circ} 48^{\prime} 41^{\prime \prime}$ ). The drainage area for the station is $8.30 \mathrm{mi}^{2}$ (square miles) and periods of no streamflow are generally of short duration.

\section{Furnace Fork}

Furnace Fork flows to Millers Creek which is tributary to the Kentucky River. The Irvine-Furnace Field in Estill and Powell Counties was discovered in 1915 (Freeman, 1951), and oil has been produced in the watershed for about 80 years. Oil-production activities occur mainly in the headwater catchment areas of the $9.94 \mathrm{mi}^{2}$ watershed, and little or no production occurs in some catchments. Oil production has been from the "Corniferous zone" with wells commonly ranging in depth from 200 to 1,000 feet. Secondary water flooding methods have been successfully used in parts of the field. Most of the companies currently active in the field are classified as small operators (less than six production wells), and many wells are are privately owned. Records of oil production are proprietary information and generally were not available. At least one facility is permitted to discharge brine to streams in the Furnace Fork watershed, but is limited to a total discharge of 12 pounds of chloride per day (Kentucky Division of Water, written communication, 1990).

The Furnace Fork watershed (fig. 2) was chosen for study because of its long history of oil production, and because reconnaissance sampling indicated that Furnace Fork might not be as greatly affected by oil-production activities as many other creeks in the Kentucky River basin. Three samples obtained in the Furnace Fork watershed during the 1985-87 reconnaissance had chloride concentrations which ranged from 302 to $1,154 \mathrm{mg} / \mathrm{L}$. The oil field was operational but many oil wells were not used during the study. There is good access, and most tributaries are accessible along paved all-weather roads. The valley is populated, so several wells and springs used for domestic water supply were available for sampling. Finally, a bridge was conveniently located at the lower end of the watershed for the installation of a monitoring station. Furnace Fork was gaged on the downstream side of a box culvert on a county road in Estill County, about 2.9 miles south of Fitchburg, and 2.5 miles northwest of Crystal (latitude $37^{\circ} 41^{\prime} 21^{\prime \prime}$, longitude $83^{\circ} 51^{\prime} 27^{\prime \prime}$ ).

\section{Big Sinking Creek}

The Big Sinking Creek watershed (fig. 2) was selected for study due to extensive production activities in the watershed, and also because of large chloride concentrations in the creek during reconnaissance sampling. Three samples obtained in the Big Sinking Creek watershed during the 1985-87 reconnaissance had chloride concentrations which ranged from 852 to 8,165 
$\mathrm{mg} / \mathrm{L}$. A site for streamflow and water-quality monitoring was available near the mouth. The Big Sinking Creek gaging station was installed on the downstream side of a highway bridge about 2.7 miles southeast of Crystal in Lee County (latitude $37^{\circ} 38^{\prime} 22^{\prime \prime}$, longitude $83^{\circ} 47^{\prime} 05^{\prime \prime}$ ). All known ollproduction activities of the watershed are in the $23.4 \mathrm{mi}^{2}$ drainage area upstream of the station. Big Sinking Creek flows to Millers Creek which is tributary to the Kentucky River.

The Big Sinking Field, primarily in the Big Sinking Creek watershed, was discovered in 1917 or 1918. Oil production occurs at depths of 800 to 1,300 feet in the "Corniferous zone." Water flooding was initiated following the decline of primary oil production in the area, and more than 1,000 wells have been used for injection. Some producers in the Big Sinking Field utilize impoundments of freshwater or freshwater mixed with treated brine for the water flooding operations. Water produced with the oil is commonly released to surface streams, but some is disposed in a highly porous dolostone unit of the "Corniferous zone." There are at least 17 facilities in the Big Sinking Creek watershed which are permitted to discharge brine to streams. The total amount of chloride which is permitted for release to streams is slightly more than 2,000 pounds per day (Kentucky Division of Water, written communication, 1990).

\section{ASSESSMENT APPROACH}

Three watersheds were chosen for study of the occurrence, movement, quality, and interaction of surface and ground water in oil-producing areas of the Kentucky River basin. For this study, two watersheds that had a long history of oil production and a similar watershed that had little or no history of oil production were selected. Selection of the watersheds was based on production history of the oil fields in each watershed, and on chloride concentrations in streams sampled during water-quality reconnaissance surveys by the Kentucky Geological Survey during the period 1985-87. The watersheds selected for this study were Big Sinking Creek, Furnace Fork, and Cat Creek (fig. 2).

Oil production was active in the Furnace Fork and Big Sinking Creek watersheds prior to and during the study. The Big Sinking Creek watershed was believed to be more heavily affected by oil-production activities than the Furnace Fork watershed. Although adjacent to the Furnace Fork watershed and underlain by similar geology, no oll production was known to have occurred in Cat Creek watershed prior to or during the study and the occurrence and chemical characteristics of water in the Cat Creek watershed were assumed to be representative of natural conditions. The Cat Creek watershed was the study control on which comparisons were based for assessment of oil production effects on the occurrence and characteristics of water in the two o11production watersheds studied.

Ground-water data of the Kentucky River basin were summarized to characterize "unaffected" water quality of selected formations. We1ls G2, G3, and 616-20 were sampled by the U.S.Geological Survey in the Kentucky River basin, but outside of the oil-production areas (fig. 1). Specific conductance of water from several shallow dug wells, springs, and drilled wells in Furnace Fork watershed was measured in April 1987 to determine if oil-production 
activities had affected water supplies utilized for domestic supply. Four monitoring wells (G4, G5, G10, and G12) were installed to different depths in bedrock in the summer of 1988 to investigate water quality and head relations of ground water in the Furnace Fork watershed. These wells were located near the middle of the watershed (fig. 2), and included: well G12 in the "Corniferous zone" beneath the New Albany Shale, well G10 in the New Albany Shale, well G4 in the basal part of the Borden Formation and top of the New Albany Shale, and shallow well G5 in the Borden Formation (fig. 5). Head relations were defined to assess the potential for interaction of water between the different geologic formations. Ground-water samples from the Big Sinking Creek and Furnace Fork watersheds were obtained during September 1988 to describe water-quality changes due to water flooding for secondary oil recovery and due to ground-water/surface-water interactions. Sampling sites included the four monitoring wells in the Furnace Fork watershed, dug wells and springs used as domestic supplies, and brines from actively pumping oil wells.

Surface-water resources of the three watersheds were determined by monthly and storm-event sampling, and by continuous monitoring (30-minute interval) of streamflow and specific conductance from April 1987 through March 1989. Using relations of specific conductance to selected dissolved constituents, continuous records of selected constituents were synthesized for the period April 1987 through March 1989. Because the maximum specific conductance recorded on Big Sinking Creek and Furnace Fork greatly exceeded that of their respective monthly samples, the relations between specific conductance and dissolved constituents were based on both the monthly stream samples and on samples of separator discharge obtained upstream. Unlike data for Cat Creek and Big Sinking Creek, a single relation could not be developed between specific conductance and concentrations of bromide, chloride, and sodium for samples from Furnace Fork. Therefore, relations were defined for separate ranges of specific conductance in Furnace Fork, one for values of specific conductance less than about 500 to $600 \mu \mathrm{S} / \mathrm{cm}$ (microsiemens per centimeter at $25^{\circ} \mathrm{C}$ ), and one for larger values.

Loads of selected constituents in the streams draining the three study watersheds were estimated from the continuous streamflow and constituent concentration records. Loads and yields based on periodic water-quality samples and the discharge record from April 1, 1987, through March 31, 1989, were estimated for several water-quality constituents using methods described by Smoot and others (1990). Monthly streamflow measurements and samples for chloride and bromide were collected for 2 years from six tributary streams upstream of the continuous monitoring site on Furnace Fork to further define constituent sources and transport mechanisms.

Two low-flow synoptic samplings were conducted at 75 sites to determine the concentration and distribution of major ions throughout the Kentucky River basin. One sampling was conducted August 24-28, 1987, and the other was conducted August 8-12, 1988. The primary use of synoptic sampling is to provide a fine degree of spatial resolution to the descriptions of selected water-quality constituents. Samples were obtained from a large number of sites in a short time span to minimize differences due to changing hydrologic conditions. Selection of the sampling sites was based on geographic coverage, geology, land use, and locations of known point and nonpoint sources. Point- 
source inputs tend to dominate the system during low-flow conditions. Sampled constituents included barium, bromide, chloride, sodium, and strontium which were considered to be representative of oil-production activities.

The overall effect of oil-brine discharges on the Kentucky River was assessed using water-quality and streamflow records collected by the U.S. Geological Survey at Lock 10, and water-quality records of the Kentucky American Water Company for the river 8.2 miles downstream from Lock 10 (fig. 1). In addition, the relation between the quantity of oil produced in the basin and constituent transport in the Kentucky River was also investigated.

Daily summaries of the continuous (30-minute interval) records of discharge and specific conductance of Big Sinking Creek, Cat Creek, and Furnace Fork for the period April 1987 to March 1989, and all water-quality data obtained during the study were published in the annual data reports for Kentucky (Garcia, Sholar, and Toms, 1988 and 1989).

\section{EFFECTS OF OIL PRODUCTION ON GROUND WATER}

\section{Ground-Water Occurrence and Character in Unaffected Watersheds}

Most water wells in the study area produce less than 500 gal/d (gallon per day) (Price, Kilburn, and Mul1, 1962; and Hall and Palmquist, 1960). No information is available to indicate the affect of oil production on well yields. The Pennsylvanian rocks (Breathitt and Lee Formations) generally supply from 100 to $500 \mathrm{gal} / \mathrm{d}$, but yields are less on hillsides and narrow ridge tops. The Newman Limestone usually yields only minor quantities of water where overlain by rocks of Pennsylvanian age on the ridges in the Cat Creek and Furnace Fork watersheds. Elsewhere in the Kentucky River bas in the Newman Limestone has yielded more than $50 \mathrm{gal} / \mathrm{min}$ (gallon per minute) in some of the karst areas, and this may occur in the Cat Creek and Furnace Fork watersheds. Pennsylvanian rocks overlie the Newman Limestone in most of the Big Sinking Creek watershed, and the Newman Limestone yields only small quantities of water in this watershed. Typical yields for the Borden Formation are 100 to $500 \mathrm{gal} / \mathrm{d}$.

In order to assess the effects of oil production on ground-water quality, some knowledge of the character of natural (or unaffected) ground water is necessary. However, oil production in the study area has occurred for more than 80 years and information on water quality prior to that time is not available. Analyses of water from wells outside the oil-production areas of the Kentucky River basin indicated large ranges of constituent concentrations in each geologic formation. Dissolved-solids concentrations in water from Pennsylvanian, Mississippian, Devonian, and Silurian rocks of the Kentucky River basin have been measured in excess of $100,000 \mathrm{mg} / \mathrm{L}$ (table 1). Large concentrations of most major ionic constituents and some trace elements were detected in these waters. Salty water commonly occurs in we1ls more than 100 feet in depth below major valley bottoms (Price, Mull, and Kilburn, 1962; and $\mathrm{Hall}$ and Palmquist, 1960). Thus, saline water could be expected naturally from most geologic formations in the study area. 
Hand-dug wells in the alluvium of the study area are used for domestic water supply. According to Hopkins (1966), dissolved-solids concentrations of fresh groundwater above the freshwater/saline-water interface generally range from 250 to $400 \mathrm{mg} / \mathrm{L}$, and chloride concentrations are usually between 50 and $150 \mathrm{mg} / \mathrm{L}$.

\section{Ground-Water Occurrence and Character in Oil-Production Watersheds}

\section{Ground-Water Flow Potential}

Monthly water-level data obtained from the four monitoring wells in the Furnace Fork watershed from July 1988 to March 1989 indicate that ground-water flow potential is primarily to the basal part of the Borden Formation from underlying and overlying units (fig. 5). The shallow well in the Borden Formation (G5) had water levels within 10 feet of ground surface, and the well in the basal Borden Formation (G4) typically had water levels between 65 and 80 feet below land surface. The water levels in the New Albany Shale well (G10) were consistently higher than in the basal Borden Formation well, and ranged from 10 to 37 feet below land surface. Water-level measurements in a "Corniferous zone" well (site G12) ranged from 32 to 66 feet below land surface and were consistently lower than those in an overlying New Albany Shale well (site G10). The lower head in the "Corniferous zone" in relation to that in the New Albany Shale is probably a result of pressure declines caused by pumping oil and water from the "Corniferous zone" during the past 80 years of production in the watershed. Even though the New Albany Shale apparently acts as a confining bed, fractures or leaky well bores could allow movement of water upward from the "Corniferous zone" through the shale and into the basal part of the Borden Formation.

\section{Ground-Water Quality}

Specific conductance measurements of water obtained April 14-16, 1987, from shallow dug wells in the alluvium, deeper drilled bedrock wells, and springs used for domestic supply indicate that waters from some bedrock springs and shallow wells in the alluvium of the Furnace Fork watershed are not saline, but saline water is likely in the deeper formations. The specific conductance of nine springs and seven relatively shallow wells ( 3 to 63 feet deep) located throughout the watershed ranged from 50 to $440 \mu \mathrm{S} / \mathrm{cm}$. Two Borden Formation wells drilled 68 and 82 feet deep in the central part of the watershed produced water with a specific conductance greater than $1,000 \mu \mathrm{S} / \mathrm{cm}$.

Water sampled from the alluvium in the Furnace Fork watershed was not widely affected by oil-production activities based on comparison with baseflow samples from the unaffected Cat Creek control watershed. Concentrations of total dissolved solids in water samples from shallow dug wells and springs in the Furnace Fork watershed (sites G1, G6, G7, G8, and G9) ranged from 161 to $320 \mathrm{mg} / \mathrm{L}$ (table 2). Constituent concentrations in water from these shallow wells and springs was also within the ranges cited by Hopkins (1966) for water from alluvial aquifers above the freshwater/saline-water interface. The maximum chloride concentration determined in water from these sites was only $17 \mathrm{mg} / \mathrm{L}$, and bromide concentrations were all less than $0.05 \mathrm{mg} / \mathrm{L}$. These waters were also within drinking water standards for all measured constituents 


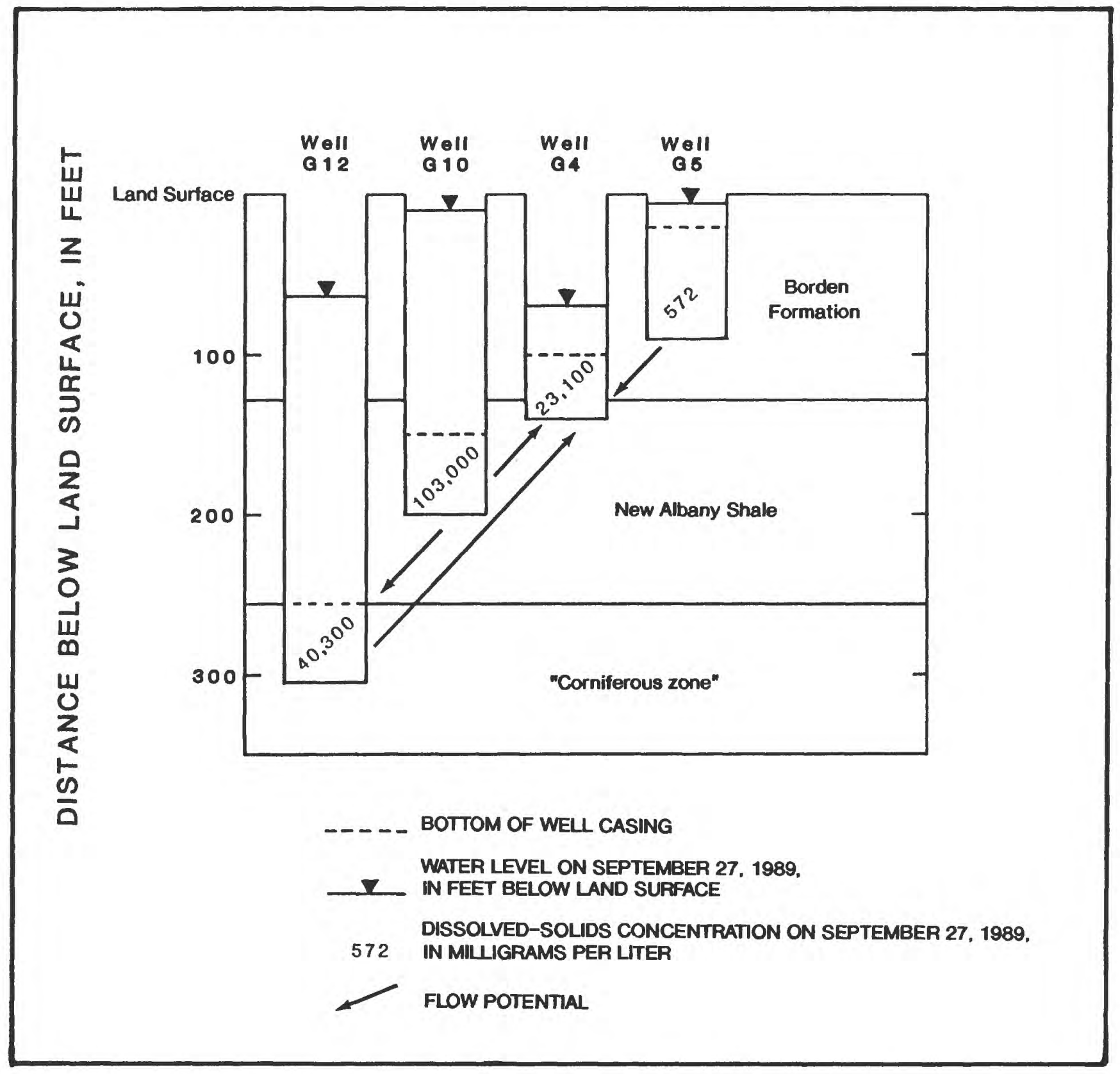

Figure 5.--Monitoring wells in bedrock in the Furnace Fork basin showing water levels and dissolved-solids concentrations on September 27, 1989. 
except for manganese. The manganese concentration of $440 \mu \mathrm{g} / \mathrm{L}$ (microgram per liter) determined in well G7 exceeded the EPA standard of $50 \mu \mathrm{g} / \mathrm{L}$ (U.S. Environmental Protection Agency, 1990a).

Dilution of brine in the "Corniferous zone" by fresh-water flooding for secondary oil recovery was indicated by the samples from oil separators (sites G11, G13, G14, and G15) which ranged in dissolved-solids concentrations from 10,700 to $22,700 \mathrm{mg} / \mathrm{L}$ (table 2). These concentrations were far less than what is considered "natural" based on maximum observed concentrations in similar formations in other areas of the Kentucky River basin (table 1). The dissolved-solids concentration of brine from the "Corniferous zone" well (site G12) in the central part of the Furnace Fork watershed where little or no oil production occurs was $40,300 \mathrm{mg} / \mathrm{L}$ (table 2). This was greater than any of the brines measured at separator discharges in the upper parts of the watershed (table 2), but still less than half that of brine from the New Albany Shale well (site G10).

Water from the New Albany Shale well (site G10) was a brine with dissolved-solids concentration of $103,000 \mathrm{mg} / \mathrm{L}$ (table 2). This is near the maximum observed dissolved-solids concentration in water from wells in Mississippian rocks in the Kentucky River basin, and greater than observed in water from any other wells in Devonian rocks (table 1). Therefore, little or no dilution from injection activities has probably occurred in the New Albany Shale at site Glo.

Ground water in the Big Sinking Creek and Furnace Fork watersheds can generally be characterized by two water types, either calcium bicarbonate or sodium chloride. Water from the dug wells and springs is usually of the calcium bicarbonate type (sites G1, G6, G7, G8, and G9 in table 3), and water from the deeper monitoring wells and oil wells is of the sodium chloride type (sites G4, G10, G11, Gl2, G13, G14, and G15 in table 3). Water from the upper part of the Borden Formation (site G5) is an exception, however, and seems to be transitional between the two water types. Mass balance analysis suggests that water from the shallow Borden Formation is similar to a mixture of approximately 99-percent fresh water (based on water from well G7) and only 1 -percent water from the "Corniferous zone."

Water sampled from the basal part of the Borden Formation (site G4) may also reflect mixing of shallow freshwater and saline water from deeper units. Based on water levels in the monitoring wells (fig. 5), the source of sodium chloride type water to the basal part of the Borden Formation could be from the New Albany Shale, or from the "Corniferous zone" provided a means of connection exists such as leaky well bores. A mass balance analysis of the sodium and chloride composition of water from the basal part of the Borden Formation (site G4) was conducted using waters from the "Corniferous zone" (site G12) and water from a shallow source (site G7). The result of this mass balance analysis indicates that water from the lower Borden Formation could result from a mixture of approximately one-third fresh water and two-thirds water from the "Corniferous zone." 


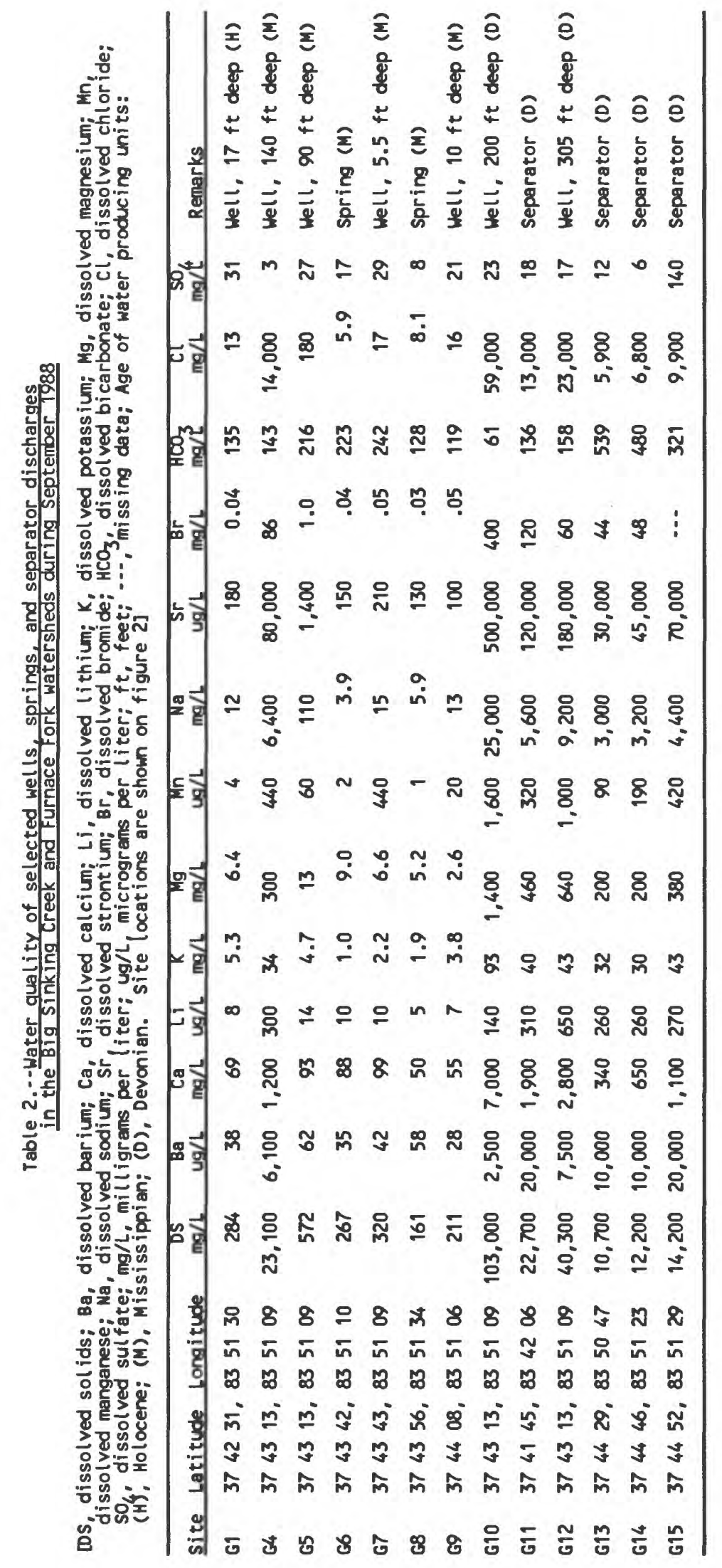




\section{Surface-Water Occurrence and Character in Unaffected Watersheds}

The occurrence and character of water draining the Cat Creek watershed was used to describe unaffected (natural) conditions. Water-quality analyses from samples of Cat Creek from April 1987 to March 1989 are summarized in figure 6. Streamflow, constituent concentration, and constituent transport data of the Cat Creek watershed was compared with corresponding data of the Furnace Fork and Big Sinking Creek watersheds to assess the effects of oilproduction on water quality.

The flow in Cat Creek generally decreased from spring through summer and increased fall through winter (fig. 7). Hydrographic recession was steep and zero flow periods occurred at times, indicating that little sustained groundwater discharge occurs in the watershed. The annual yield of water from the Cat Creek watershed, based on the period April 1987 to March 1989, was 2.44 $\left(\mathrm{ft}^{3} / \mathrm{s}\right) / \mathrm{mi}^{2}$ (cubic foot per second per square mile).

Specific conductance during April 1987 to March 1989 ranged from 50 to $750 \mu \mathrm{S} / \mathrm{cm}$ in Cat Creek, and the general pattern was one of gradual increase from mid-winter through summer and a sharp decrease from fall through early winter (fig. 8). Concentrations of bromide and chloride varied directly with specific conductance, therefore the synthesized continuous records for these constituents were similar to the specific conductance record. Synthesized chloride concentrations ranged from 0.2 to $213 \mathrm{mg} / \mathrm{L}$, and synthesized bromide concentrations ranged from less than 0.01 to $1.4 \mathrm{mg} / \mathrm{L}$.

Dissolved-solids and chloride concentrations in 14 base-flow samples of Cat Creek obtained during this study ranged from 153 to $294 \mathrm{mg} / \mathrm{L}$, and from 7.2 to $84 \mathrm{mg} / \mathrm{L}$, respectively. Because the ranges of these constituents in base flow of Cat Creek are lower than those described by Hopkins (1966) for fresh water, it was assumed that in general the Cat Creek base flow must come from above the freshwater/saline-water interface. However, during periods of extended low flow the water in Cat Creek becomes more mineralized which indicates that a non-fresh source of water also contributes to the flow of Cat Creek.

Water in Cat Creek generally was the calcium-bicarbonate type, except about 10 percent of the time when specific conductance was high and chloride was the dominant anion (fig. 9). Bromide exceeded 0.1 percent of the total anionic species present also about 10 percent of the time (fig. 10). These assessments are based on relations between specific conductance and dissolved constituents (table 4), and specific conductance duration statistics computed from Cat Creek monitoring records for the period April 1987 through March 1989. The percentages of chloride, bromide, and sodium all vary directly with specific conductance (figs. 9 and 10). Specific conductance was generally greatest in the late fall during extreme low flow. Elevated bromide, chloride, and sodium concentrations occurred when specific conductance was greater than $500 \mu \mathrm{S} / \mathrm{cm}$. 


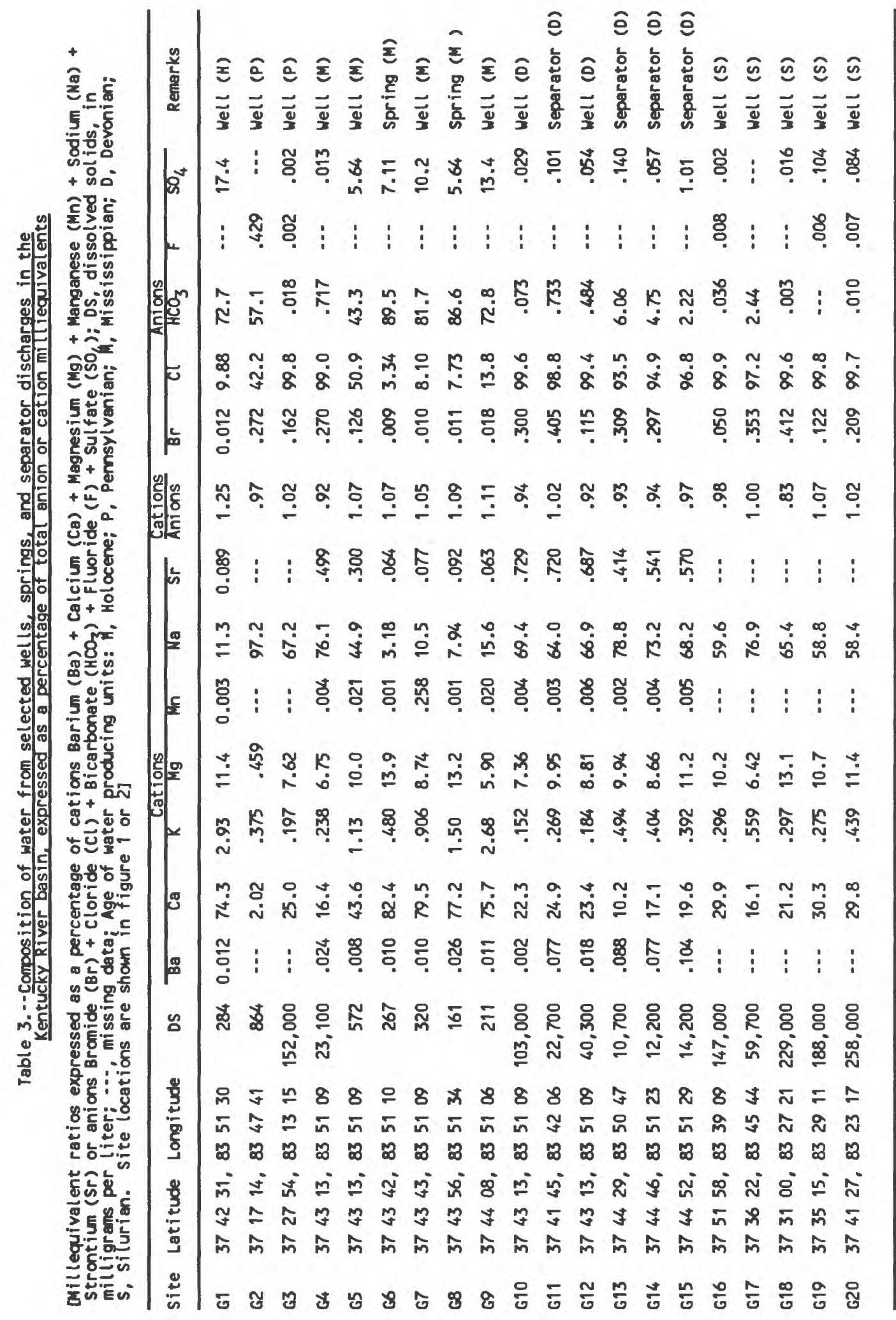



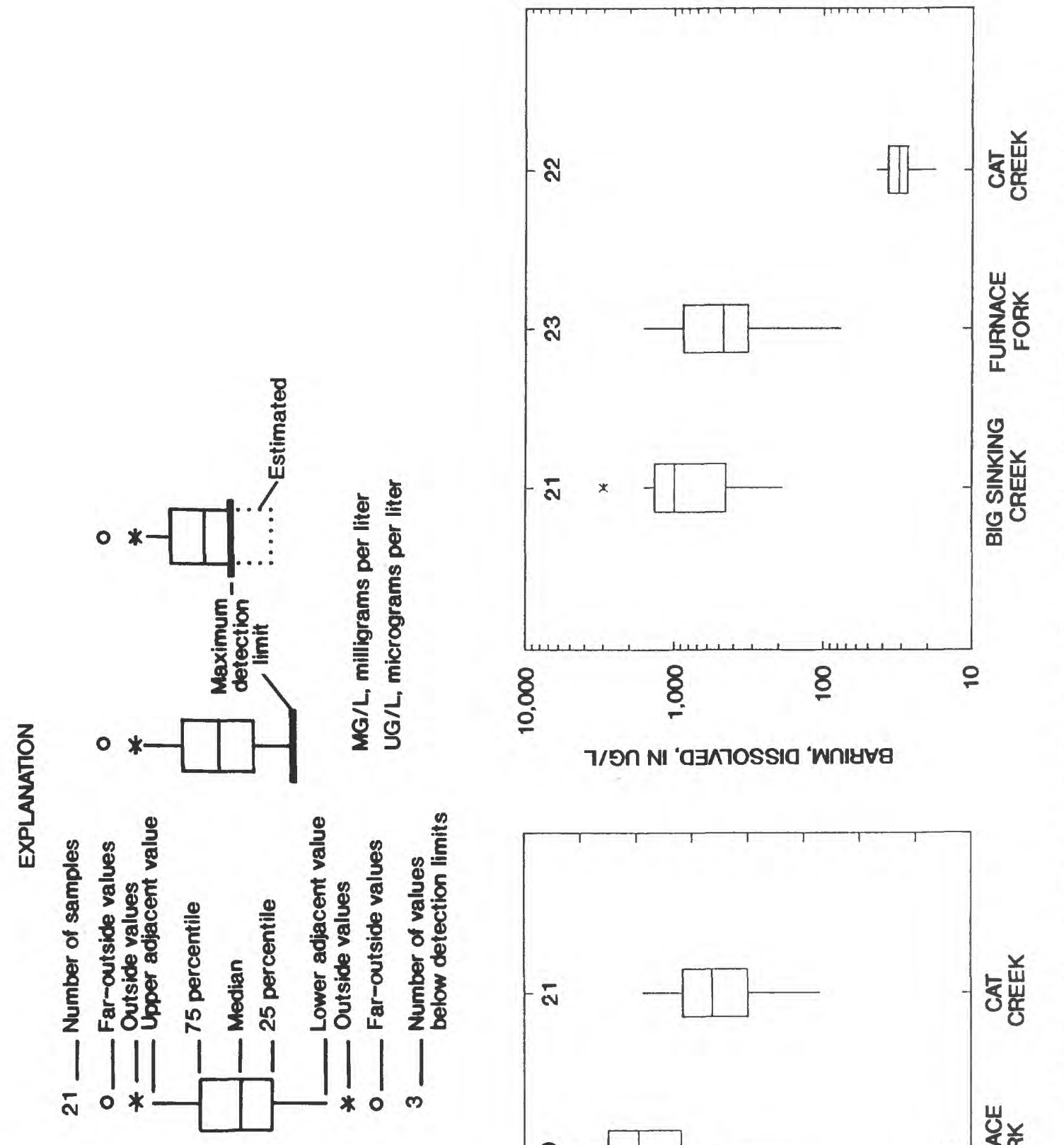

눙

บ)

ปั่

웅

등

๘ -

음 웛

E은

은

क

동

車

둥은

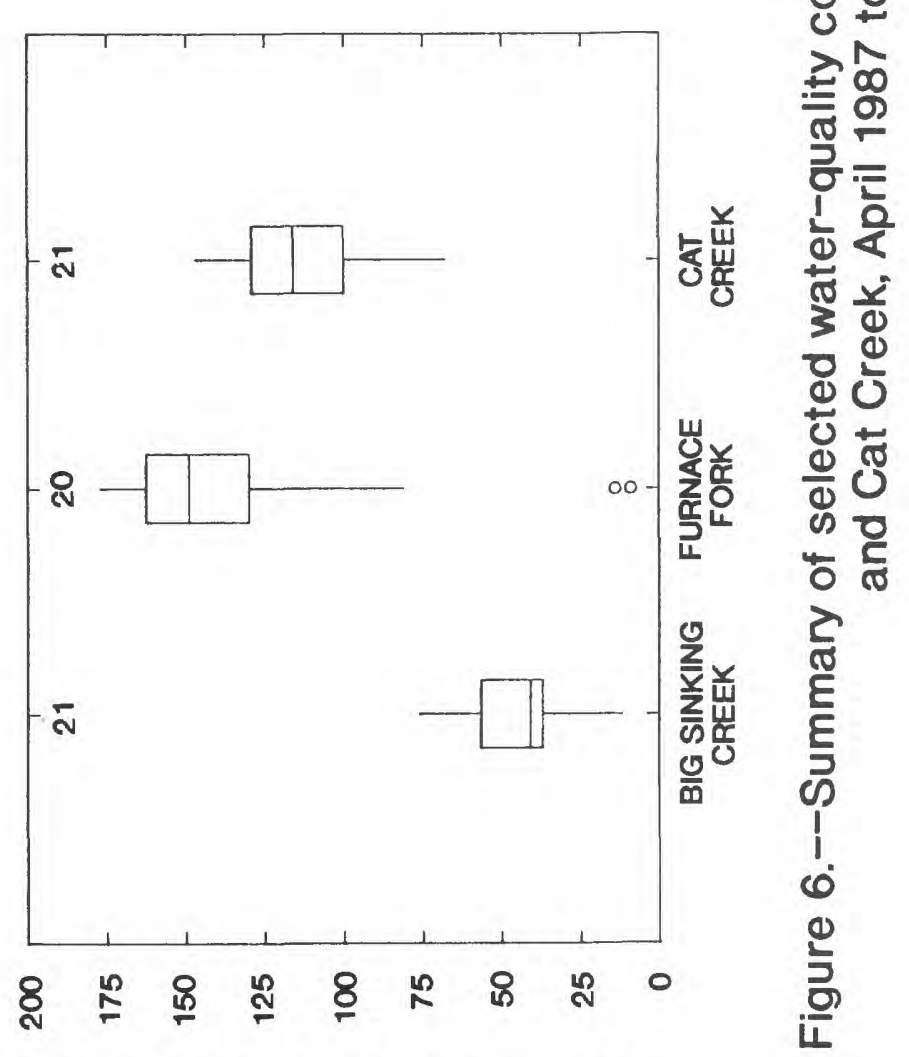

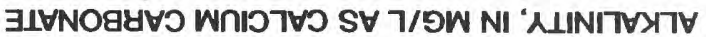




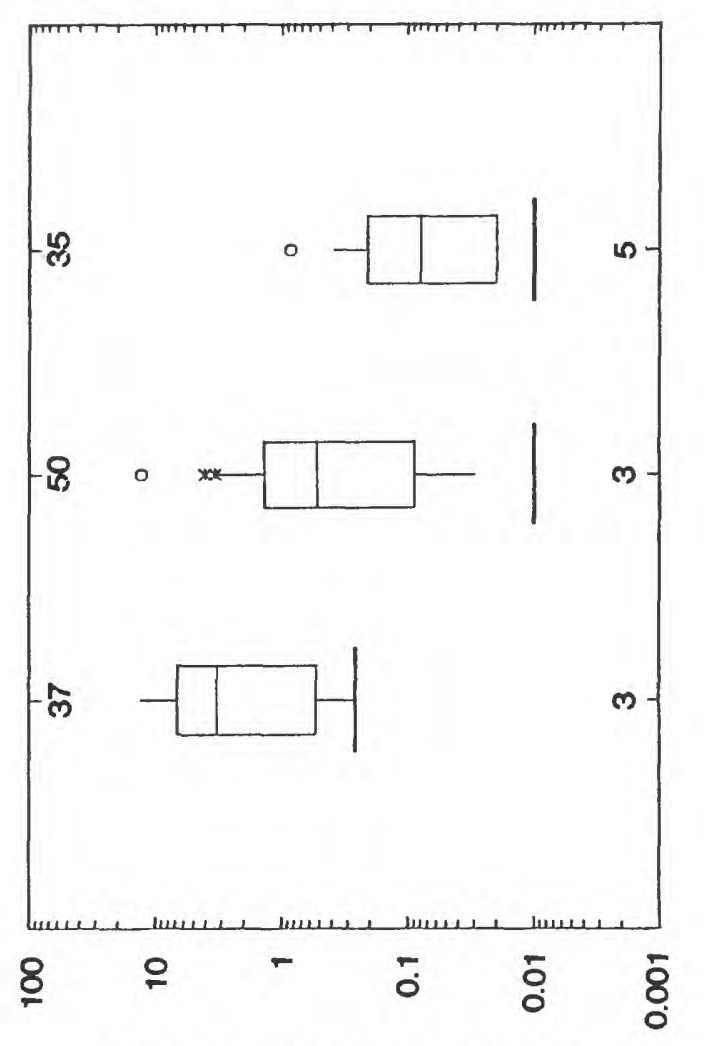

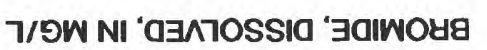

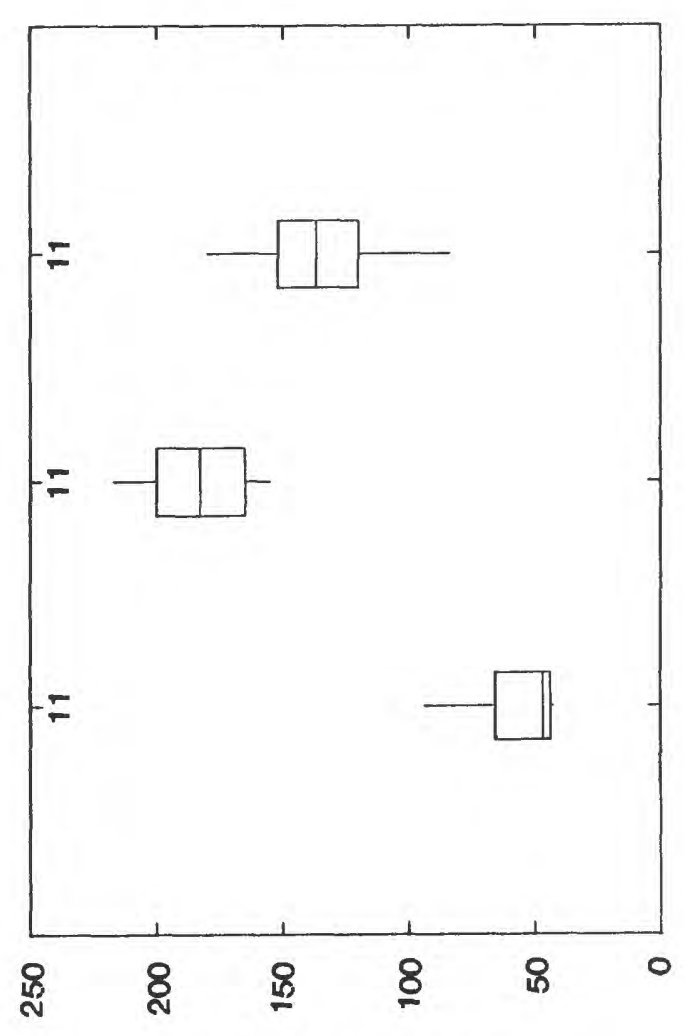

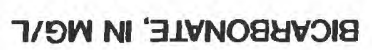

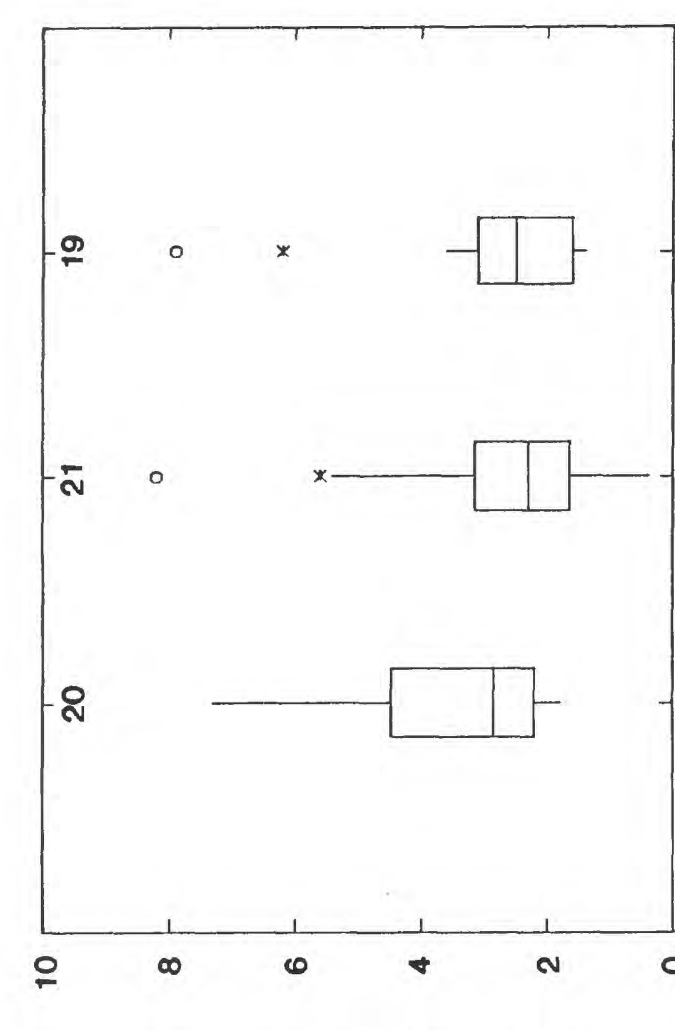

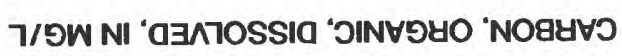

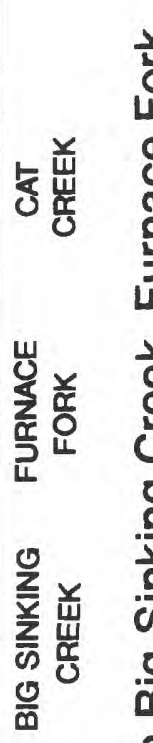

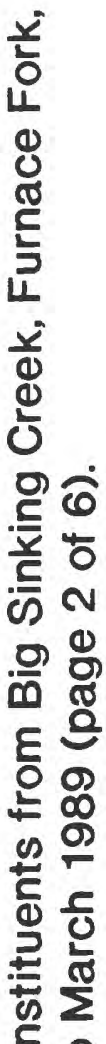

웅

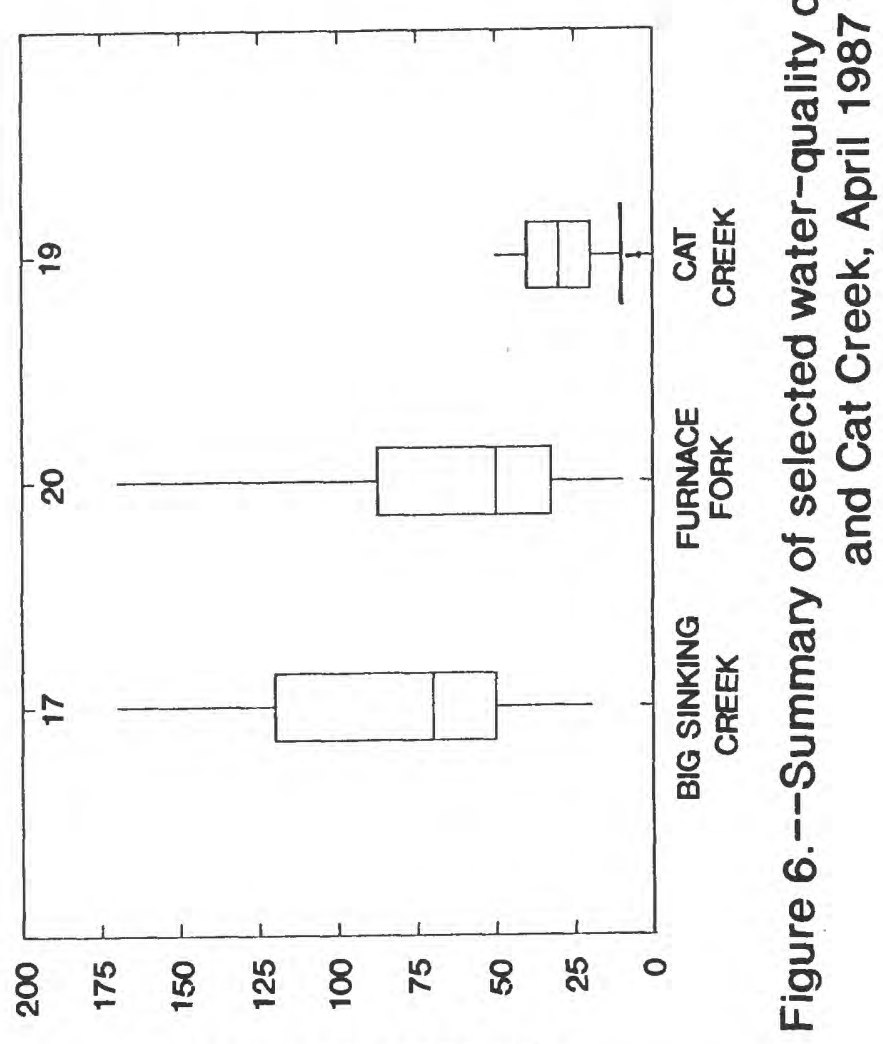

7/פก NI ' 

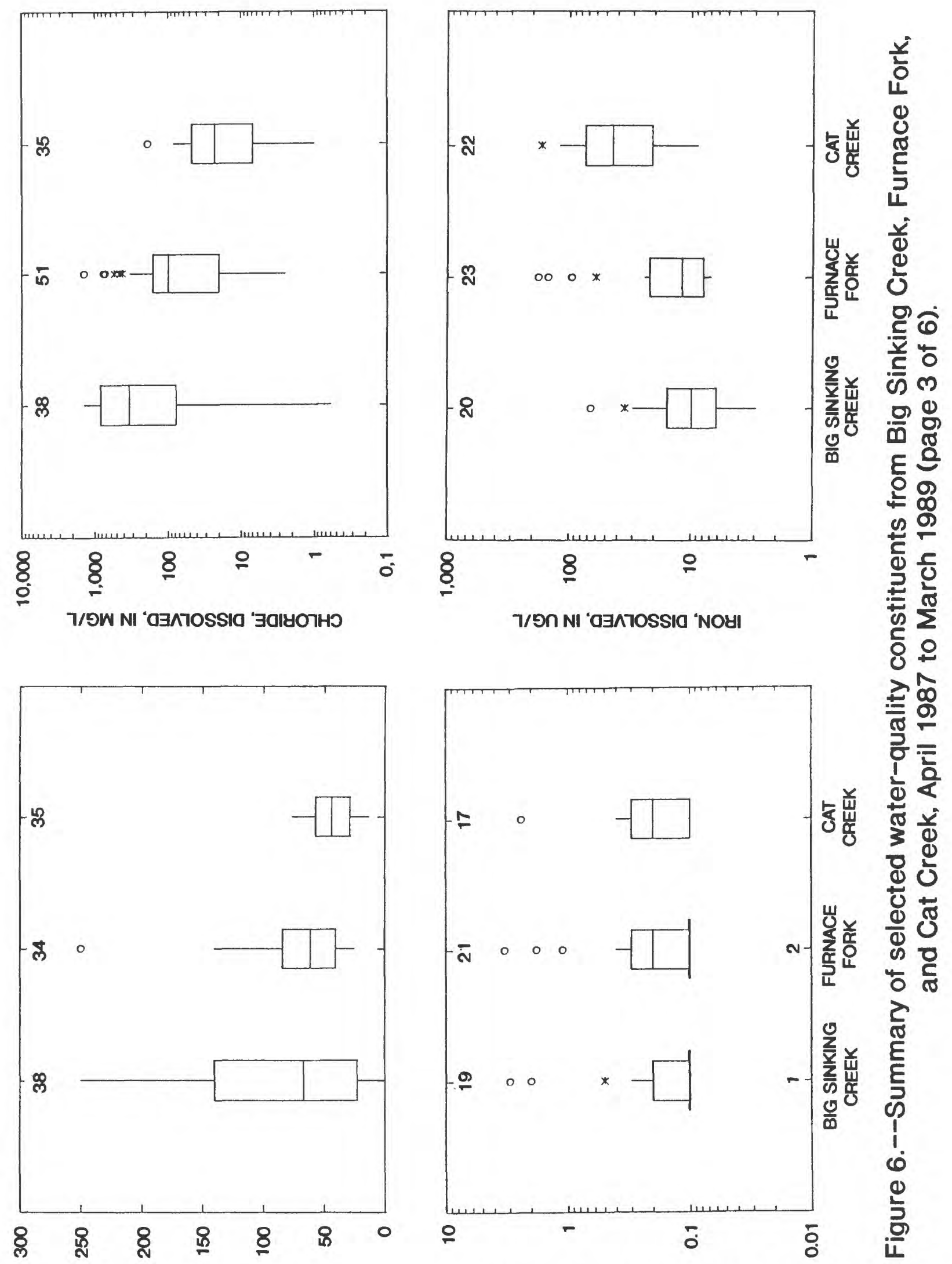

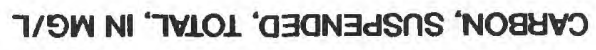




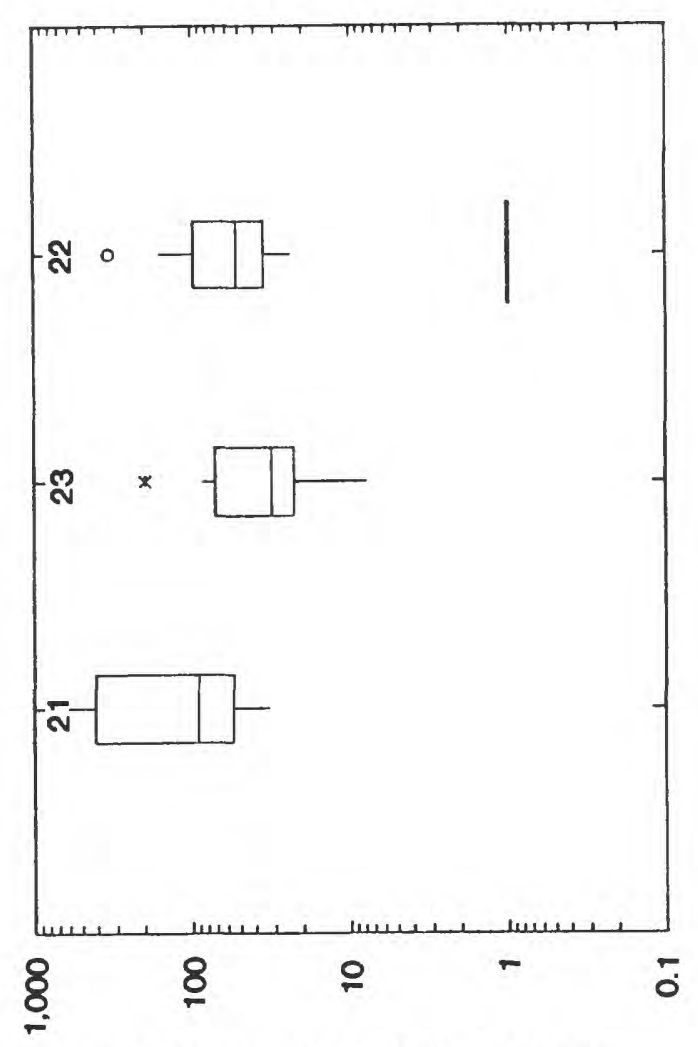

ר/פก NI "ם

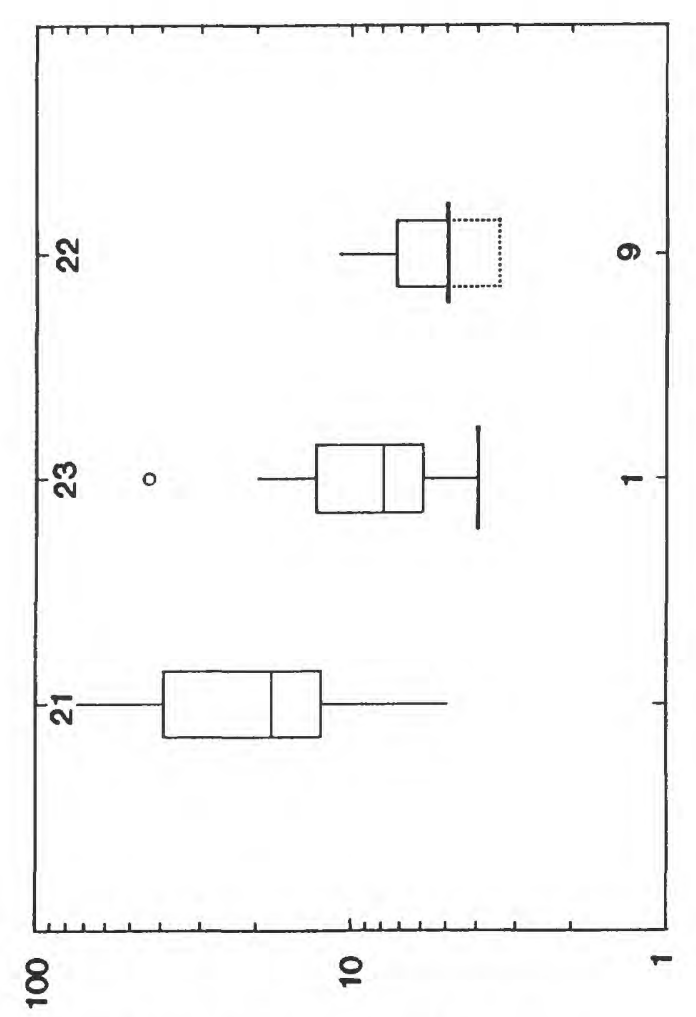

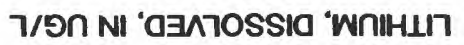
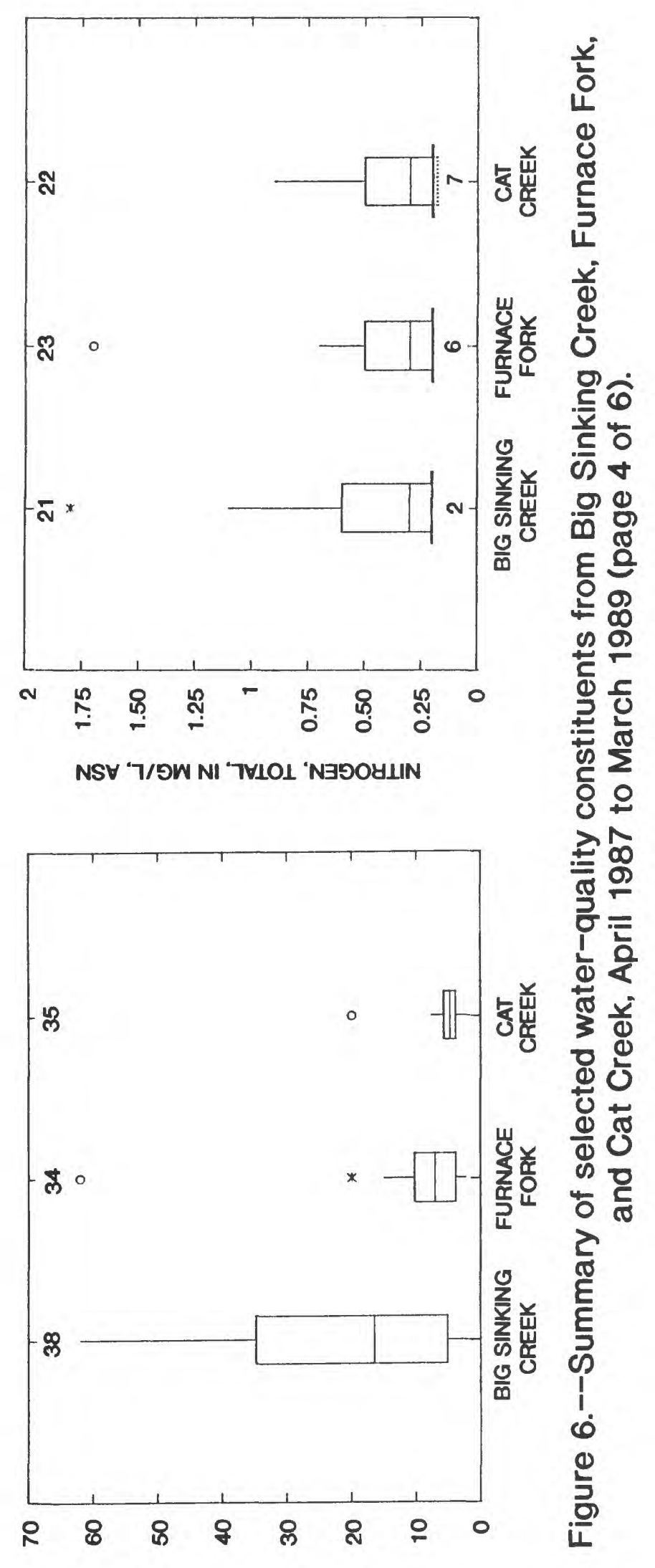

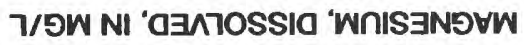




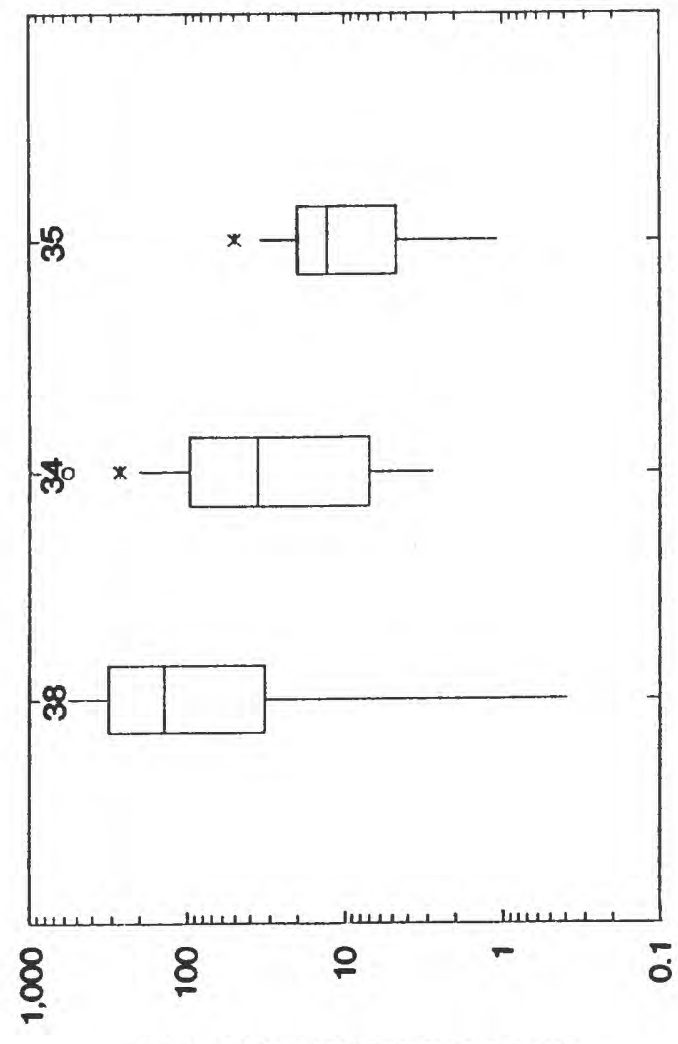

7/9W NII "םヨ^าossia 'wniaos

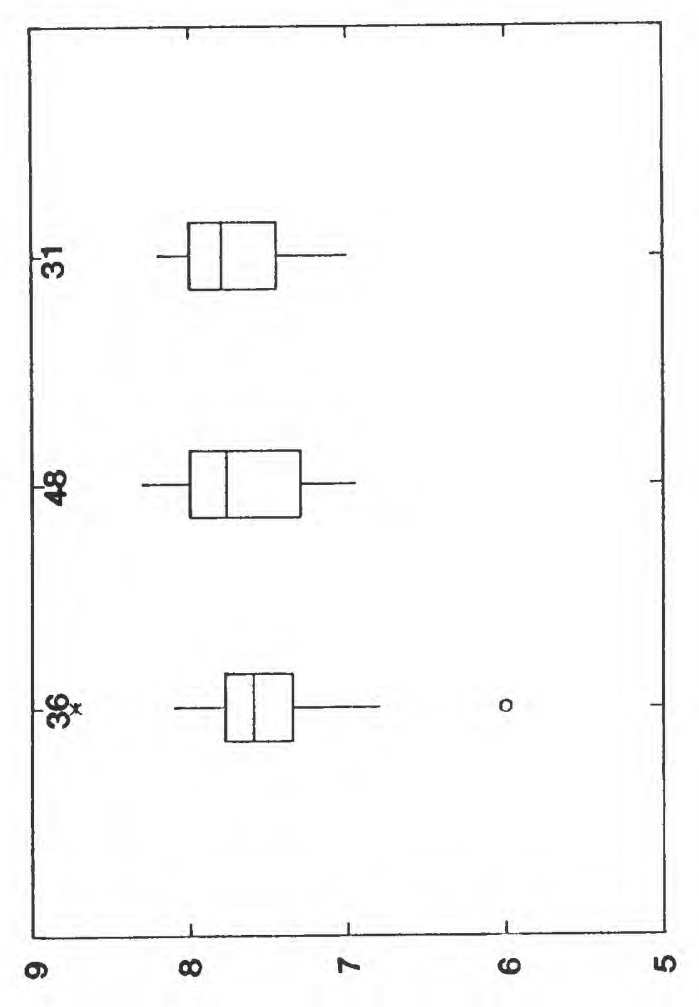

SIINก aUVANYIS NI "Hd

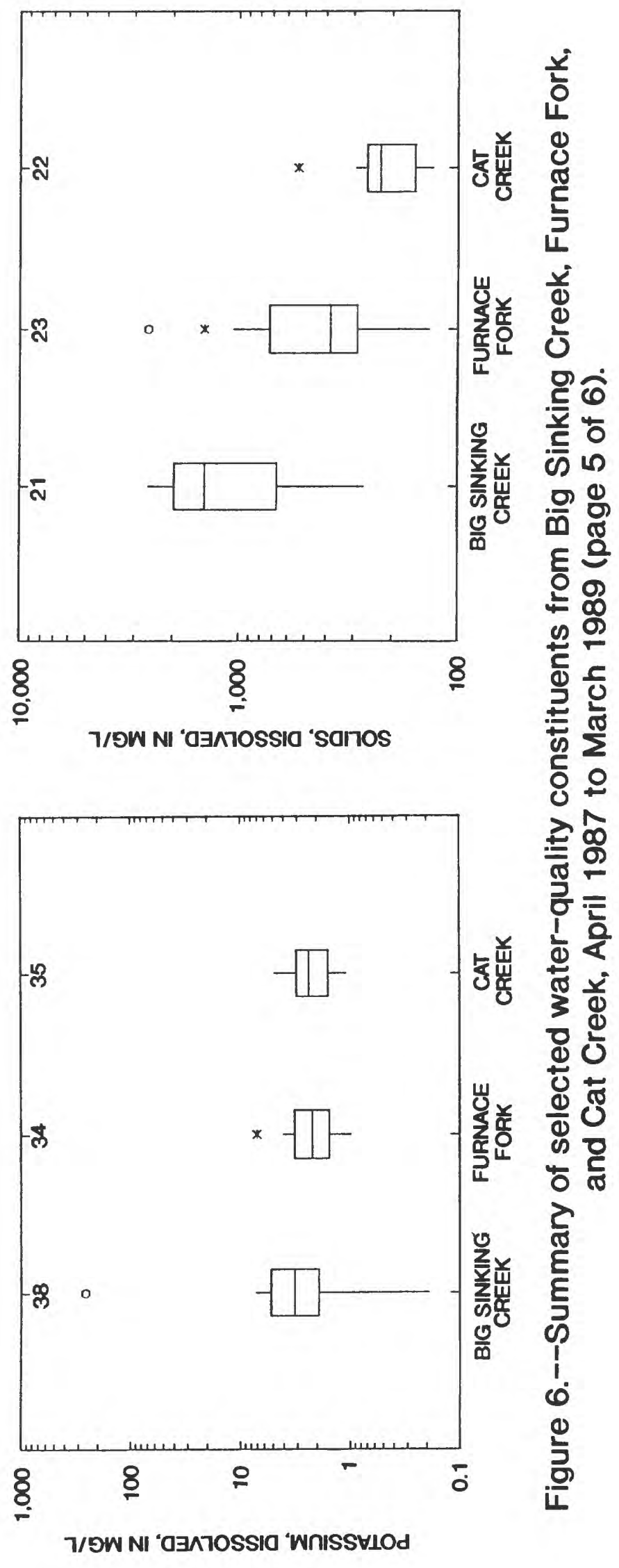




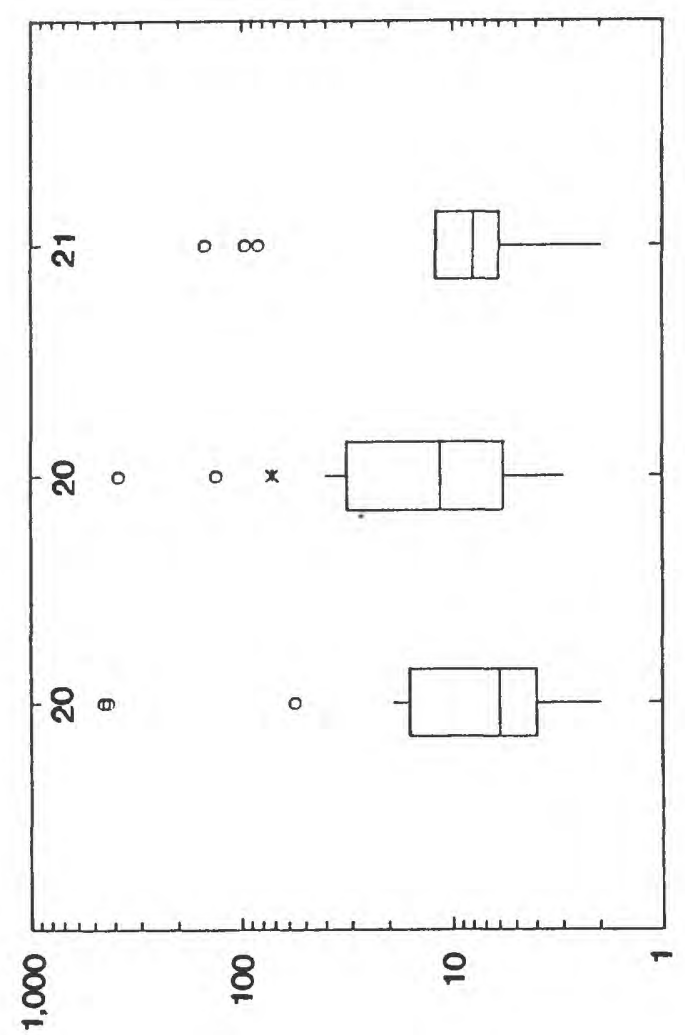

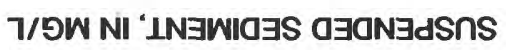

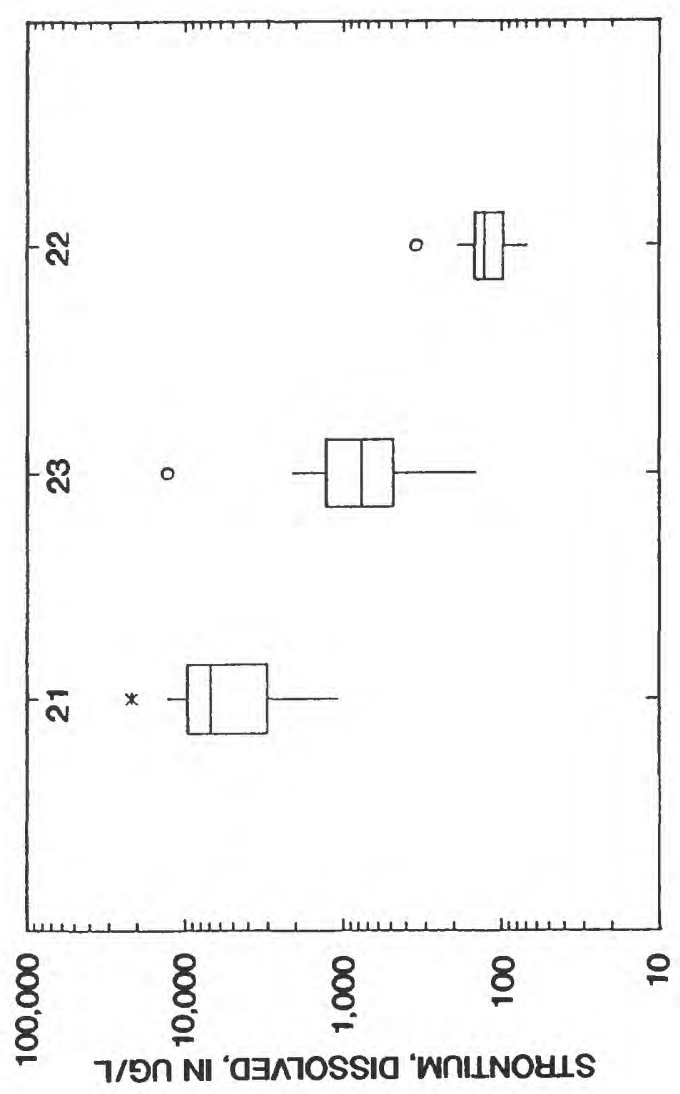

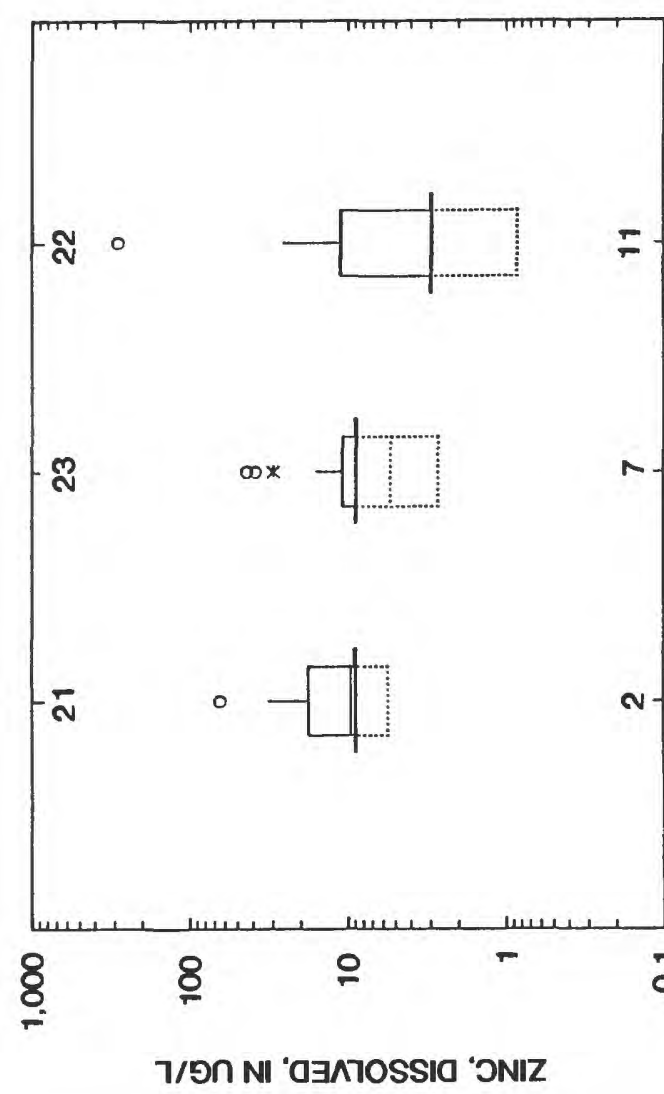

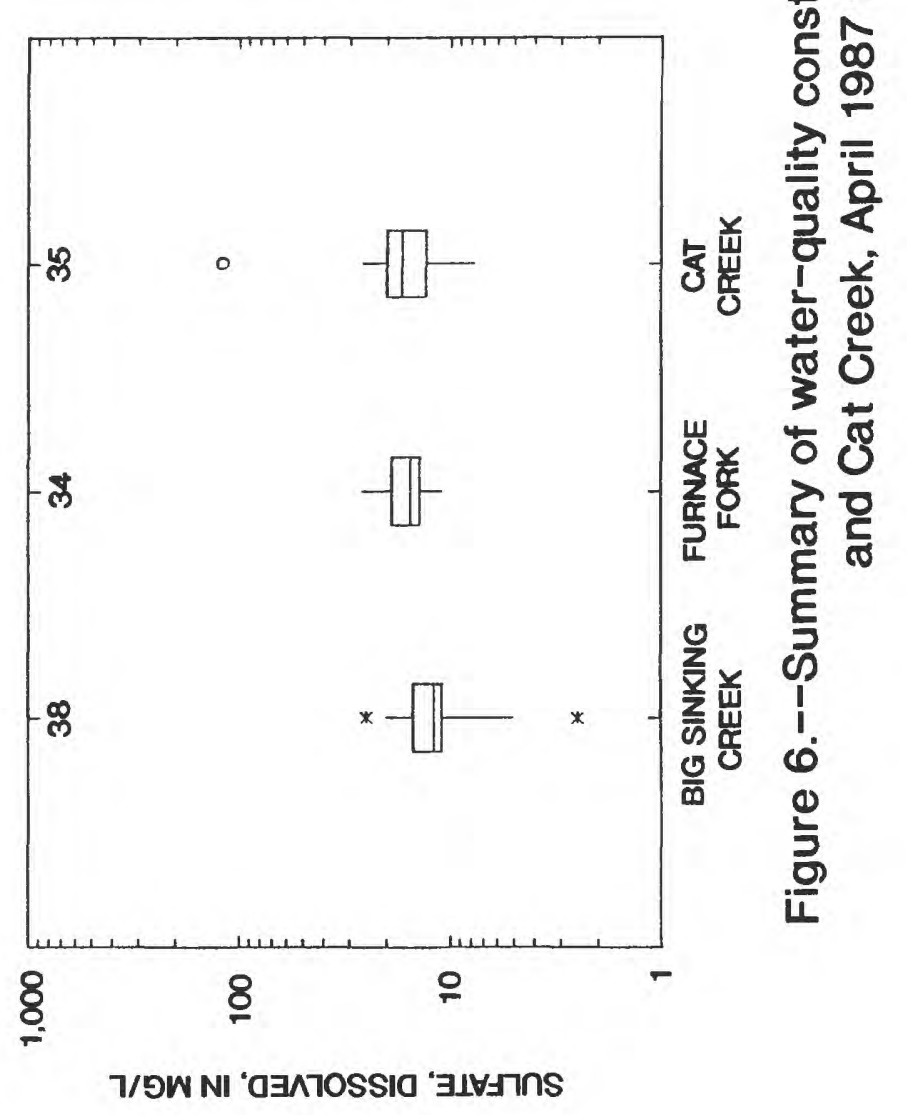



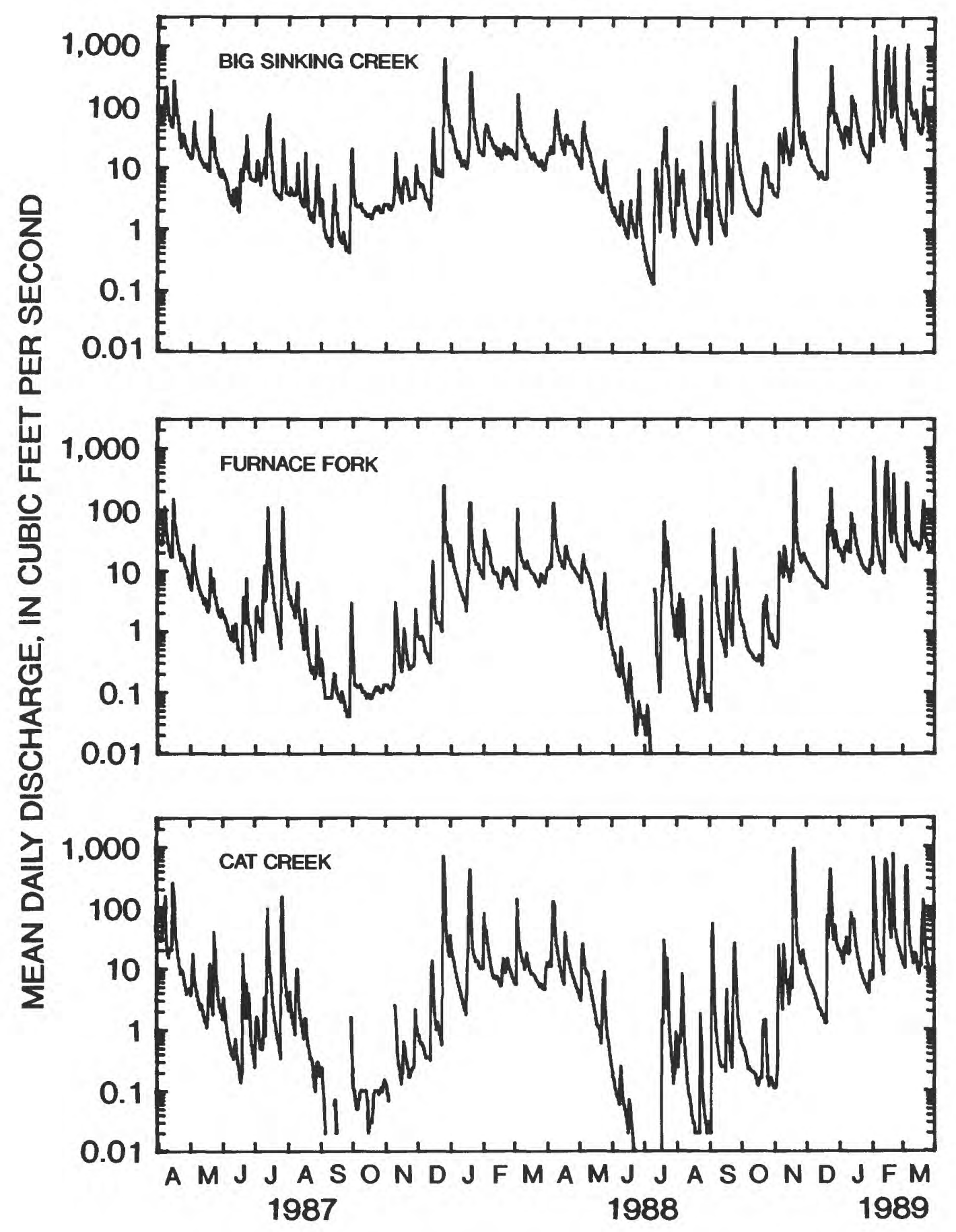

Figure 7.--Discharge of Big Sinking Creek, Furnace Fork, and Cat Creek, April 1987 to March 1989. 


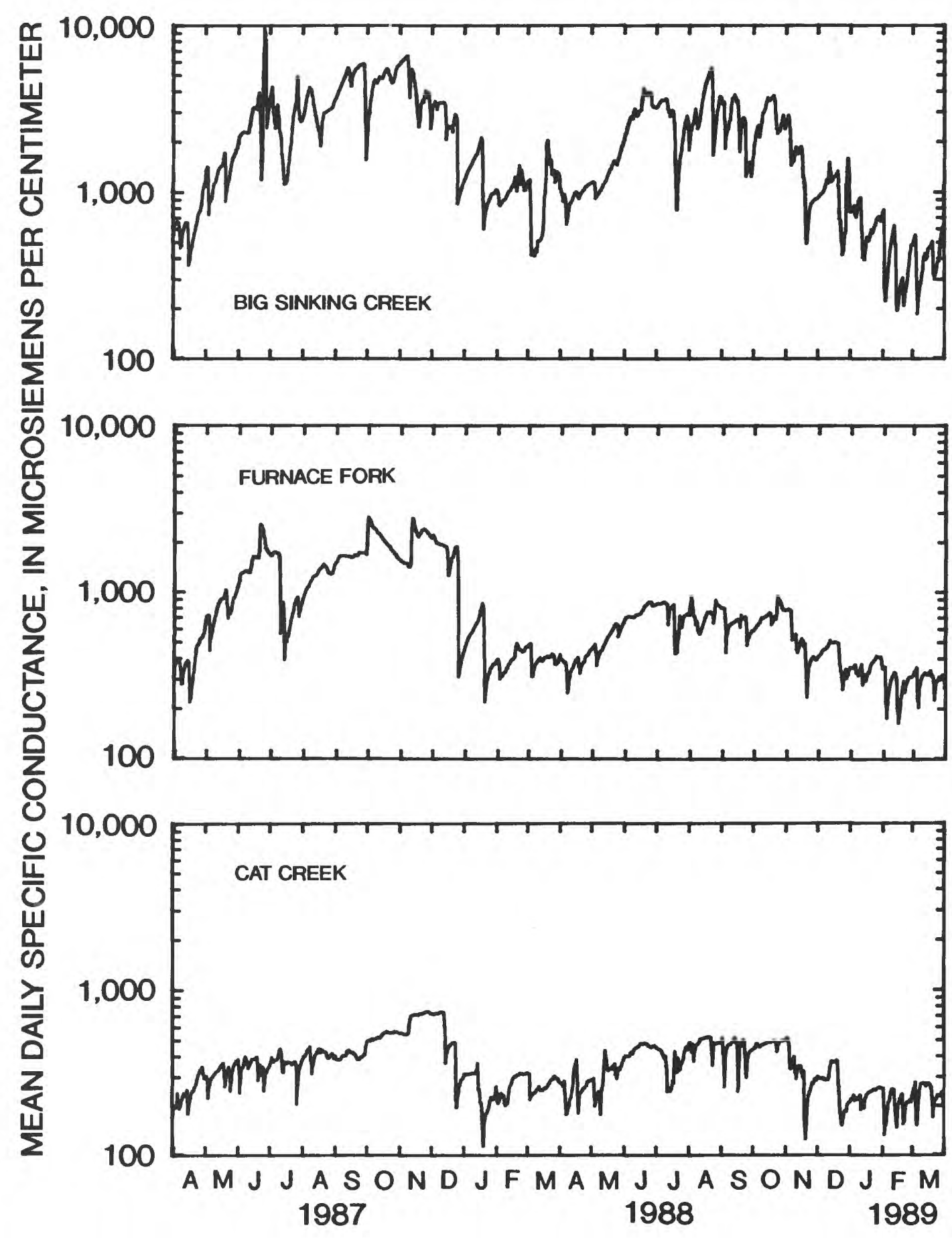

Figure 8.--Specific conductance of Big Sinking Creek, Furnace Fork, and Cat Creek, April 1987 to March 1989. 
Average annual transport of approximately 3,500 tons of dissolved solids occurred from the Cat Creek watershed during the period April 1987 through March 1989 (table 5). More than half of this annual load consisted of carbonates (carbonate plus bicarbonate), and about 15 percent was calcium. of the annual dissolved constituents transported from the Cat Creek watershed, less than 5 percent (160 tons) was chloride, and less than 0.01 percent (0.7 tons) was bromide. The yield of chloride and bromide from the Cat Creek watershed for the period April 1987 through March 1989 was 19 and 0.08 tons $/ \mathrm{mi}^{2}$ (ton per square mile), respectively (table 5).

\section{Surface-Water Occurrence and Character in 0il-Production Watersheds}

Seasonal variations in streamflow from the two oil-production watersheds were similar to that of Cat Creek; flow was generally decreasing from spring through summer and generally increasing from fall through winter (fig. 7). The annual yield of water from the Furnace Fork watershed, based on the period April 1987 to March 1989, was 1.67 ( $\left.\mathrm{ft}^{3} / \mathrm{s}\right) / \mathrm{mi}^{2}$ which is about 30 percent less than that from the Cat Creek watershed. Water yield from the Big Sinking Creek watershed of $1.51\left(\mathrm{ft}^{3} / \mathrm{s}\right) / \mathrm{mi}^{2}$ was similar to that of the Furnace Fork watershed. The reasons for the higher water yield from the Cat Creek watershed than from the Furnace Fork or Big Sinking Creek watersheds are unknown.

The general pattern of specific conductance in Big Sinking Creek and Furnace Fork was similar to that of Cat Creek, with gradually increasing values from mid-winter through summer and sharply decreasing values fall through early winter ( $\mathrm{fig} .8$ ). Specific conductance values for Big Sinking Creek and Furnace Fork were consistently higher than that in Cat Creek. The specific conductance of Big Sinking Creek was higher than the maximum observed values in Cat Creek ( $750 \mu \mathrm{S} / \mathrm{cm}) 80$ percent of the time, and the specific conductance of Furnace Fork was higher than the maximum observed values for Cat Creek 40 percent of the time. Specific conductance monitored in Big Sinking Creek ranged from about 200 to almost $10,000 \mu \mathrm{S} / \mathrm{cm}$. Specific conductance values in Furnace Fork ranged from 150 to almost 3,000 $\mu \mathrm{S} / \mathrm{cm}$.

The consistently higher specific conductance of water draining the oilproduction watersheds was believed to be principally due to separator discharges. Three brine samples from oil separators were obtained in the Furnace Fork watershed (sites G13, 14, and 15), and one was obtained in the Big Sinking Creek watershed (site G11) (table 2). These separator brines were discharged directly to streams in their respective watersheds. Dissolved solids concentrations of the sampled separator discharges in the Furnace Fork watershed ranged from 10,700 to $14,200 \mathrm{mg} / \mathrm{L}$. The separator discharge from the Big Sinking Creek watershed contained $22,700 \mathrm{mg} / \mathrm{L}$ of dissolved solids.

Oil-production activities were the source of many dissolved constituents in water from Big Sinking Creek and Furnace Fork; among these constituents were barium, boron, bromide, chloride, magnesium, sodium, and strontium. These constituents were observed in greatest concentrations in Big Sinking Creek, which drains a watershed containing several facilities permitted to discharge oil-brine to streams. The lowest concentrations of these 
BIG SINKING CREEK
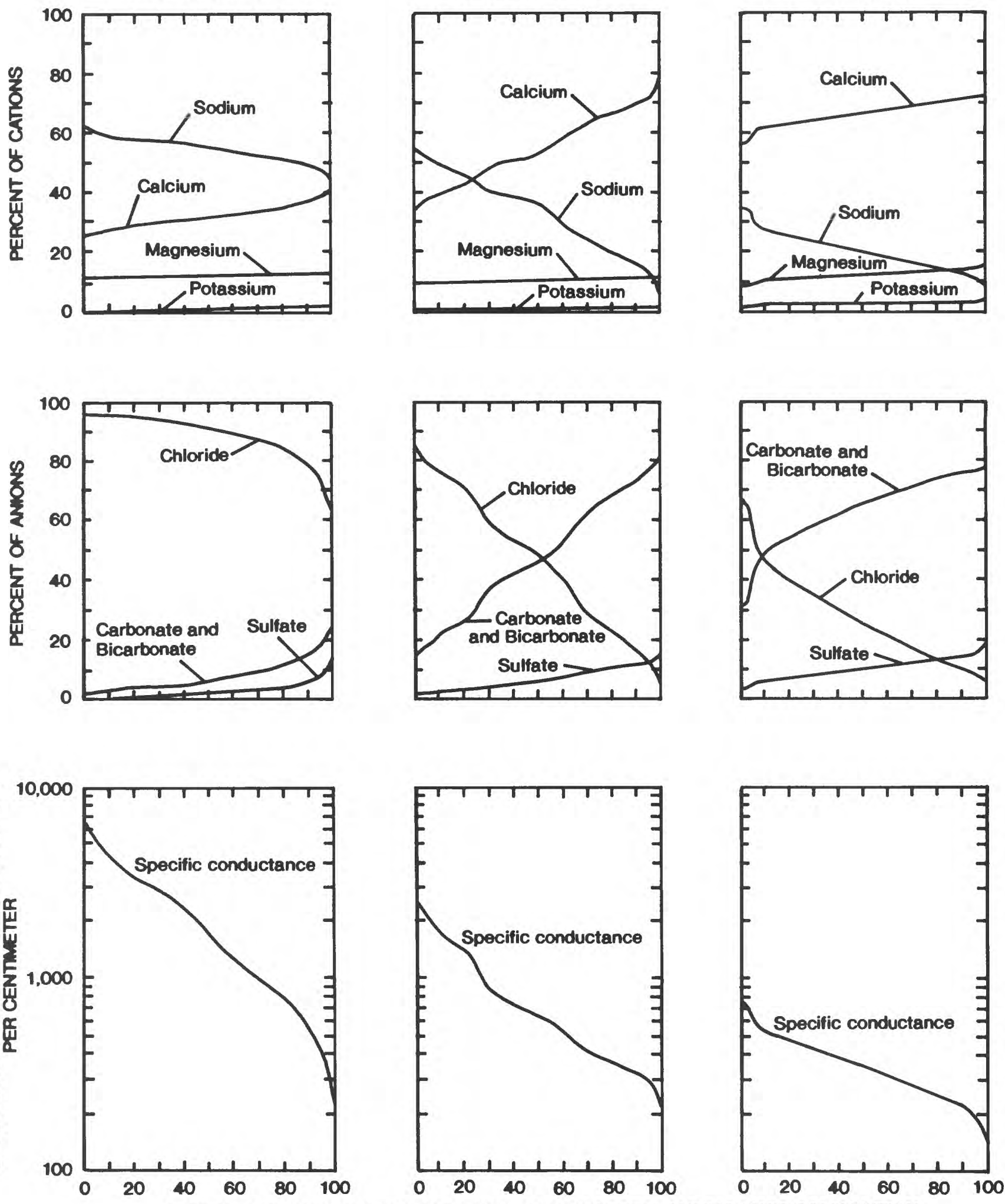

CAT CREEK

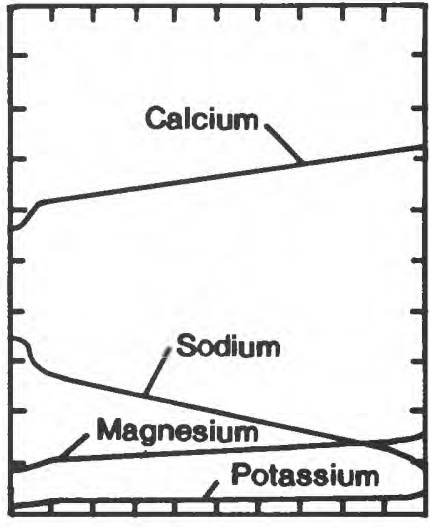

PERCENT OF TIME SPECIFIC CONDUCTANCE OR CORRESPONDING IONIC COMPOSITION

GREATER THAN OR EQUAL TO INDICATED VALUE.

Figure 9.--Duration statistics of daily specific conductance in Big Sinking Creek, Furnace Fork, and Cat Creek, and corresponding ionic composition of water, April 1987 to March 1989. 


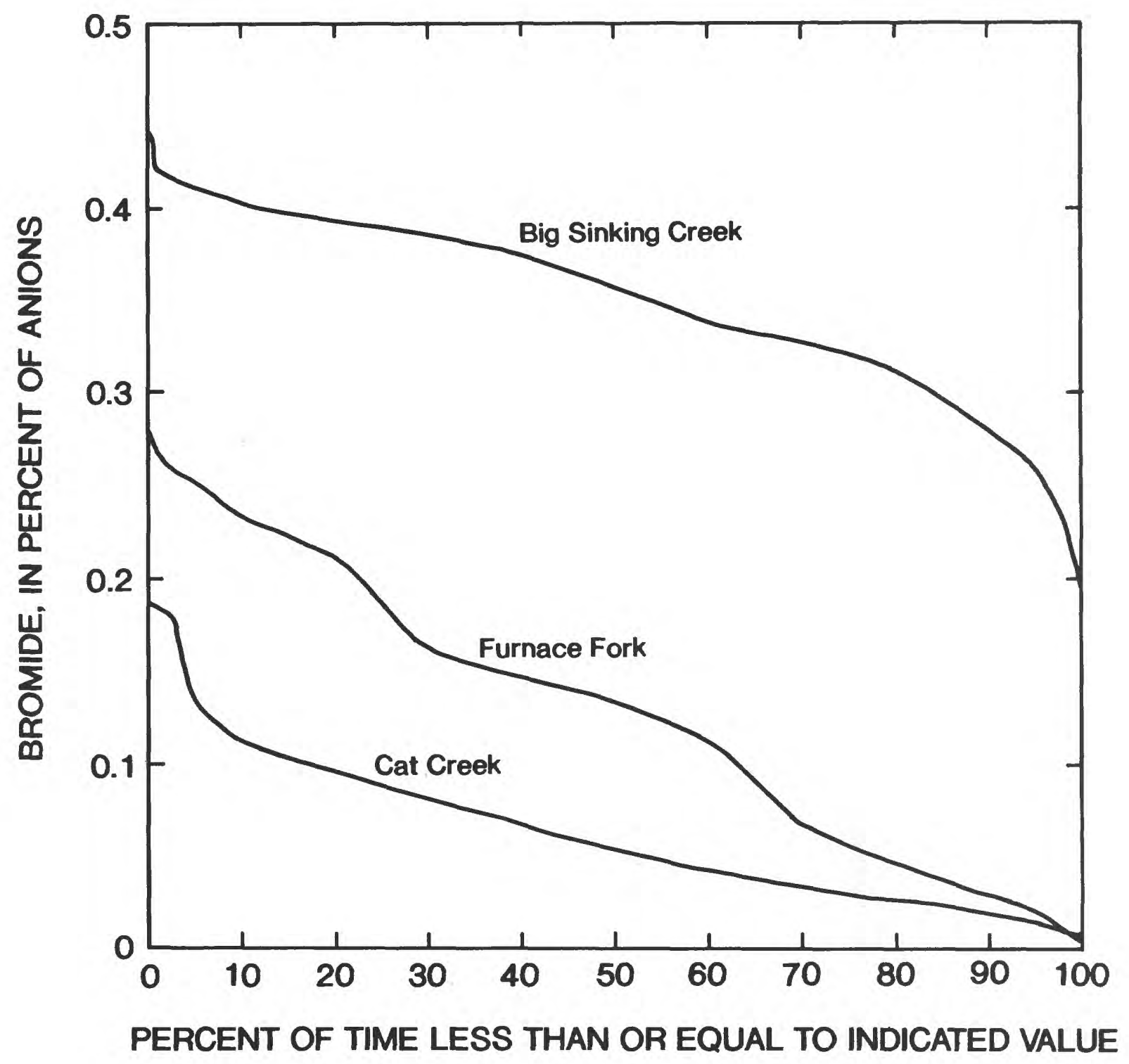

Figure 10.--Duration statistics of bromide composition in Big Sinking Creek, Furnace Fork, and Cat Creek, April 1987 to March 1989. 
Table 4.--Regression equation variables describing the relation between specific conductance and selected water-quality constituents in Big Sinking Creek, Furnace Fork, and Cat Creek

[Equation form: $y=c\left(a x^{b}\right) ; N$, number of regression data pairs; $R^{2}$, R-square of the $108-108$ regression; MSE, mean square error of the $108-10 g$ regression; Constituent units are in milligrams per liter; Constituents are in dissolved form, except alkalinity which is total as $\mathrm{CaCO}_{3}$ ]

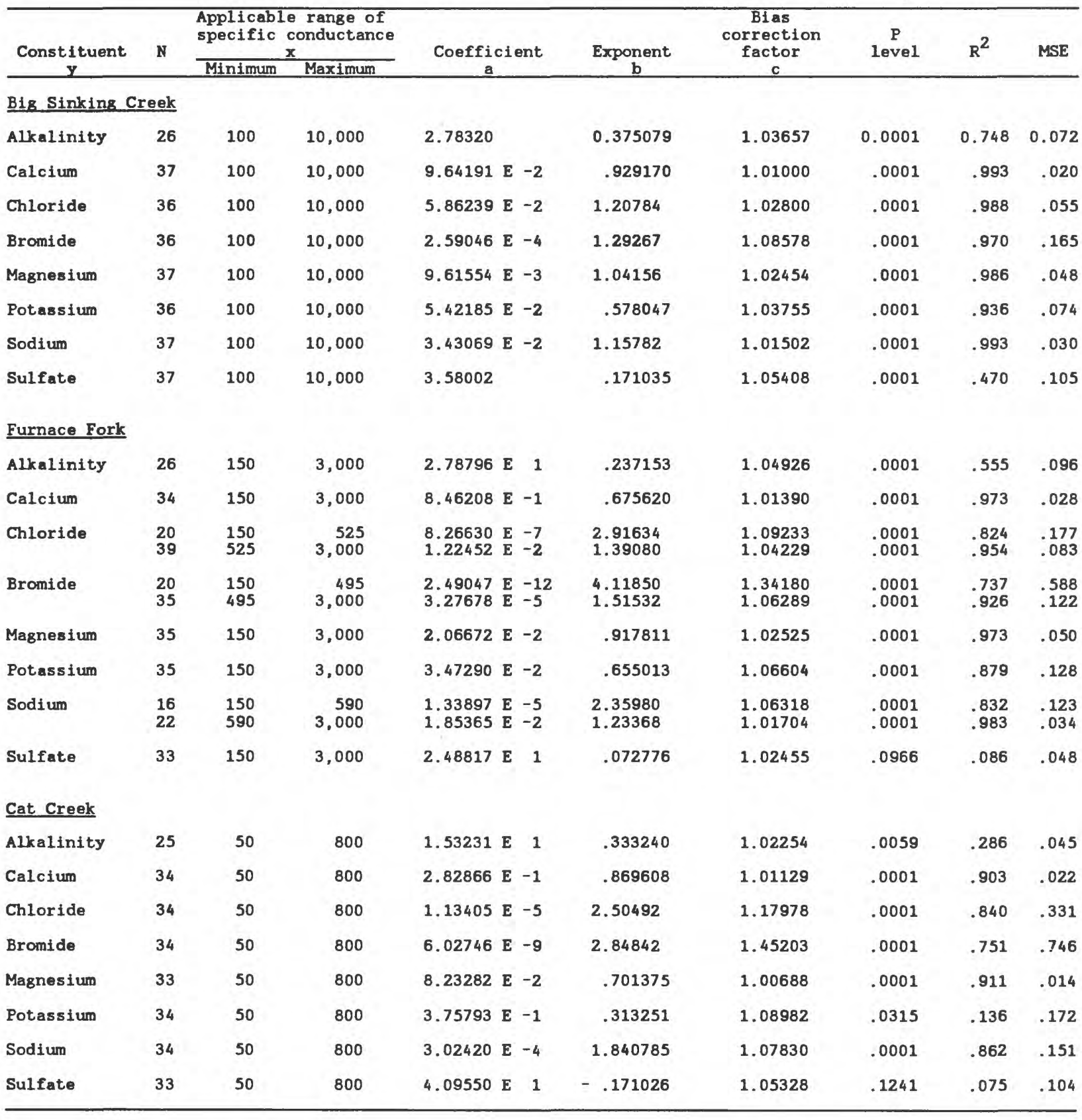


Table 5.--Average annual transport of selected water-quality constituents in Big Sinking Creek, Furnace Fork, and Cat Creek, April 1, 1987 to March 31,1989

[C, computations based on relations to continuous specific conductance record; ---, not applicable; <, less than.]

\begin{tabular}{|c|c|c|c|c|c|c|c|}
\hline \multirow{2}{*}{ Water-quality constituent } & \multirow[b]{2}{*}{$\begin{array}{l}\text { Number } \\
\text { of } \\
\text { obser- } \\
\text { vations }\end{array}$} & \multirow[b]{2}{*}{$\begin{array}{l}\text { Number } \\
\text { of } \\
\text { censored } \\
\text { values } \\
\end{array}$} & \multicolumn{2}{|c|}{ Transport estimates } & \multicolumn{3}{|c|}{ Uncertainty factors, in percent } \\
\hline & & & $\begin{array}{l}\text { Mean } \\
\text { annual } \\
\text { load, } \\
\text { in } \\
\text { tons } \\
\end{array}$ & $\begin{array}{l}\text { Mean } \\
\text { annual } \\
\text { yield, } \\
\text { in tons per } \\
\text { square mile. }\end{array}$ & $\begin{array}{l}\text { Standard } \\
\text { error } \\
\text { of } \\
\text { regression }\end{array}$ & $\begin{array}{l}\text { Flow duration } \\
\text { of } \\
\text { greatest } \\
\text { sampled } \\
\text { discharge } \\
\end{array}$ & $\begin{array}{l}\text { Portic } \\
\text { load es } \\
\text { beyond } \\
\text { of sa } \\
\text { disch }\end{array}$ \\
\hline \multicolumn{8}{|l|}{ Big Sinking Creek } \\
\hline Aluminum, dissolved & 17 & 6 & 0.73 & 0.03 & 71.9 & 7.1 & 69 \\
\hline Barium, dissolved & 21 & 0 & 12 & .50 & 50.0 & 7.1 & 30 \\
\hline Boron, dissolved & 17 & 0 & 1.2 & .05 & 44.7 & 7.1 & 35 \\
\hline Bromide, dissolved & c & --- & 57 & 2.4 & --- & -- & --- \\
\hline Calcium, dissolved & C & --- & 1,500 & 64 & -- & --- & --- \\
\hline Carbon, organic, dissolved & 20 & 0 & 130 & 5.7 & 42.6 & 7.1 & 61 \\
\hline Carbon, organic, suspended & 19 & 1 & 50 & 2.1 & 114 & 7.1 & 84 \\
\hline Carbonate + bicarbonate, dissolved & d $C$ & --- & 1,100 & 47 & --- & --- & --- \\
\hline Chloride, dissolved & C & -- & 6,600 & 280 & --- & -- & --- \\
\hline Copper, dissolved & 21 & 9 & .06 & $<.01$ & 60.7 & 7.1 & 67 \\
\hline Iron, dissolved & 21 & 0 & .37 & .02 & 94.1 & 7.1 & 51 \\
\hline Lithium, dissolved & 21 & 0 & .32 & .01 & 54.0 & 7.1 & 33 \\
\hline Manganese, dissolved & 21 & 0 & 48 & 2.0 & 86.4 & 7.1 & 88 \\
\hline Magnesium, dissolved & C & --- & 330 & 14 & --- & --- & -- \\
\hline Mercury, total & 20 & 7 & .02 & $<.01$ & 263 & 7.1 & 60 \\
\hline Nitrogen, ammonia, dissolved & 21 & 1 & 5.4 & .23 & 116 & 7.1 & 73 \\
\hline Nitrogen, ammonia + organic, total & 121 & 2 & 34 & 1.5 & 80.3 & 7.1 & 74 \\
\hline Nitrogen, $\mathrm{NO}_{2}+\mathrm{NO}_{3}$, dissolved & 21 & 2 & 8.9 & .38 & 68.6 & 7.1 & 74 \\
\hline Potassium, dissolved & c & --- & 81 & 3.4 & --- & -- & --- \\
\hline Sediment, suspended & 20 & 0 & 13,000 & 570 & 208 & 7.1 & 92 \\
\hline Silica, dissolved & 21 & 0 & 200 & 8.5 & 36.8 & 7.1 & 66 \\
\hline Sodium, dissolved & c & -- & 2,700 & 114 & --- & -- & --- \\
\hline Solids, dissolved & 21 & 0 & 16,000 & 670 & 38.2 & 7.1 & 30 \\
\hline Strontium, dissolved & 21 & 0 & 71 & 3.1 & 49.7 & 7.1 & 27 \\
\hline Sulfate, dissolved & C & --- & 390 & 16 & -- & -- & -- \\
\hline Zinc, dissolved & 21 & 2 & .37 & .02 & 107 & 7.1 & 52 \\
\hline \multicolumn{8}{|l|}{ Furnace Fork } \\
\hline Aluminum, dissolved & 22 & 1 & .10 & .01 & 59.2 & 1.5 & 25 \\
\hline Barium, dissolved & 22 & 0 & 3.7 & .38 & 54.4 & 1.5 & 20 \\
\hline Boron, dissolved & 19 & 0 & .45 & .05 & 53.3 & 1.5 & 35 \\
\hline Bromide, dissolved & C & -- & 2.6 & .26 & -- & -- & -- \\
\hline Calcium, dissolved & C & --- & 700 & 70 & -- & --- & --- \\
\hline Carbon, organic, dissolved & 21 & 0 & 65 & 6.5 & 65.4 & 1.5 & 39 \\
\hline Carbon, organic, suspended & 21 & 2 & 11 & 1.1 & 140 & 1.5 & 44 \\
\hline Carbonate + bicarbonate, dissolved & d $c$ & --- & 1,900 & 190 & -- & --- & --- \\
\hline Chloride, dissolved & C & --- & 480 & 49 & -- & --- & -- \\
\hline Iron, dissolved & 22 & 0 & .82 & .08 & 126 & 1.5 & 42 \\
\hline
\end{tabular}


Table 5. - Average annual transport of selected water-quality constituents in Big

Sinking Creek. Furnace Fork and Cat Creek, Apri1 1.1987 to March 31. 1989--Continued

\begin{tabular}{|c|c|c|c|c|c|c|c|}
\hline Water-quality constituent & $\begin{array}{l}\text { Number } \\
\text { of } \\
\text { obser- } \\
\text { vations }\end{array}$ & $\begin{array}{l}\text { Number } \\
\text { of } \\
\text { censored } \\
\text { values } \\
\end{array}$ & $\begin{array}{l}\text { Transport } \\
\text { Mean } \\
\text { annual } \\
\text { load, } \\
\text { in } \\
\text { tons } \\
\end{array}$ & $\begin{array}{l}\text { estimates } \\
\text { Mean } \\
\text { annual } \\
\text { yield, } \\
\text { in tons per } \\
\text { square mile }\end{array}$ & $\begin{array}{l}\text { Uncerta } \\
\text { Standard } \\
\text { error } \\
\text { of } \\
\text { regression }\end{array}$ & $\begin{array}{c}\text { inty factors, } 1 \\
\text { Flow duration } \\
\text { of } \\
\text { greatest } \\
\text { sampled } \\
\text { discharge }\end{array}$ & $\begin{array}{l}\text { in percent } \\
\text { Portion of } \\
\text { load estimated } \\
\text { beyond range } \\
\text { of sampled } \\
\text { discharge } \\
\end{array}$ \\
\hline \multicolumn{8}{|l|}{ Furnace Fork--Continued } \\
\hline Magnesium, dissolved & c & --- & 72 & 7.2 & --- & --- & -- \\
\hline Nitrogen, ammonia + organic, total & al 22 & 2 & 6.8 & .69 & 97.5 & 1.5 & 34 \\
\hline Phosphorus, total & 22 & 10 & .50 & .05 & 108 & 1.5 & 43 \\
\hline Potassium, dissolved & C & --- & 27 & 2.7 & --- & --- & --- \\
\hline Sediment, suspended & 19 & 0 & 1,200 & 120 & 197 & 11.5 & 77 \\
\hline Solids, dissolved & 22 & 0 & 3,900 & 400 & 55.8 & 1.5 & 21 \\
\hline Strontium, dissolved & 22 & 0 & 6.4 & .64 & 72.9 & 1.5 & 18 \\
\hline Sulfate, dissolved & c & --- & 280 & 28 & --- & --- & --- \\
\hline Zinc, dissolved & 21 & 2 & .12 & .01 & 139 & 1.5 & 28 \\
\hline \multicolumn{8}{|l|}{ Cat Croek } \\
\hline Barium, dissolved & 21 & 0 & .58 & .07 & 25.9 & 14.9 & 82 \\
\hline Boron, dissolved & 18 & 1 & .35 & .04 & 61.6 & 14.9 & 77 \\
\hline Bromide, dissolved & C & -- & .70 & .08 & --- & --- & -- \\
\hline Iron, dissolved & 21 & 0 & .82 & .10 & 86.1 & 14.9 & 85 \\
\hline Lithium, dissolved & 21 & 8 & .14 & .02 & 69.2 & 14.9 & 85 \\
\hline Magnesium, dissolved & c & --- & 63 & 7.6 & --- & --- & --- \\
\hline Manganese, dissolved & 21 & 1 & 1.2 & .14 & 245 & 14.9 & 78 \\
\hline Nitrogen, ammonia, dissolved & 21 & 4 & .40 & .05 & 178 & 14.9 & 72 \\
\hline Nitrogen, amonia + organic, total & al 21 & 7 & 3.8 & .46 & 88.2 & 14.9 & 78 \\
\hline Nitrogen, $\mathrm{NO}_{2}+\mathrm{NO}_{3}$, dissolved & 21 & 9 & 2.8 & .34 & 107 & 14.9 & 81 \\
\hline Phosphorus, total & 21 & 3 & .65 & .08 & 146 & 14.9 & 82 \\
\hline Potassium, dissolved & C & --- & 41 & 5.0 & -- & --- & --- \\
\hline Sediment, suspended & 20 & 0 & 220 & 26 & 134 & 14.9 & 76 \\
\hline Silica, dissolved & 21 & 0 & 96 & 12 & 18.3 & 14.9 & 82 \\
\hline Sodium, dissolved & C & --- & 110 & 13 & --- & --- & --- \\
\hline Solids, dissolved & 21 & 0 & 3,500 & 420 & 32.7 & 14.9 & 80 \\
\hline Strontium, dissolved & 21 & 0 & 2.5 & .30 & 37.6 & 14.9 & 82 \\
\hline Sulfate, dissolved & c & --- & 360 & 43 & --- & --- & -- \\
\hline Zinc, dissolved & 21 & 10 & .59 & .07 & 240 & 14.9 & 87 \\
\hline
\end{tabular}


constituents were observed in Cat Creek which drains a non-production watershed (fig. 6). The average concentrations of these constituents in Cat Creek were significantly different at the 5 -percent confidence interval than in Big Sinking Creek, based on Duncan's multiple-range test and on Tukey's studentized range test (Steel and Torrie, 1980).

Barium concentrations in 9 of 21 water samples from Big Sinking Creek and in 1 of 22 samples from Furnace Fork were in excess of the EPA standard of 1.0 $\mathrm{mg} / \mathrm{L}$ maximum contaminant level (MCL) for drinking water (U.S. Environmental Protection Agency, 1990b). Chloride concentrations in 9 of 34 water samples from Big Sinking Creek exceeded the Kentucky criteria of $600 \mathrm{mg} / \mathrm{L}$ for protection of warm-water aquatic habitats (Kentucky Natural Resources and Environmental Protection Cabinet, 1990).

Continuous records of chloride and bromide April 1987 to March 1989, synthesized from relations of specific conductance to selected dissolved constituents (table 4), had far greater ranges of values for Big Sinking Creek and Furnace Fork than records for Cat Creek. Chloride concentrations in Big Sinking Creek ranged from about 36 to more than $4,000 \mathrm{mg} / \mathrm{L}$. Chloride concentrations in Furnace Fork ranged from 0.9 to more than $800 \mathrm{mg} / \mathrm{L}$, and from 0.2 to $213 \mathrm{mg} / \mathrm{L}$ in Cat Creek. Bromide concentrations in Big Sinking Creek ranged from about 2.7 to almost $42 \mathrm{mg} / \mathrm{L}$. Bromide concentrations ranged from less than 0.01 to $6.5 \mathrm{mg} / \mathrm{L}$ in Furnace Fork, and from less than 0.01 to 1.4 $\mathrm{mg} / \mathrm{L}$ in Cat Creek. Based on the synthesized continuous records, chloride concentrations in Furnace Fork exceeded the Kentucky criteria of $600 \mathrm{mg} / \mathrm{L}$ for protection of aquatic habitats about 3 percent of the time. Chloride concentrations in Big Sinking Creek exceeded the $600 \mathrm{mg} / \mathrm{L}$ criteria more than 40 percent of the time.

In general, constituent concentrations were elevated during low flows in summer and fall, and smallest during high winter flow. However, the greatest bromide and chloride concentrations generally occurred during first flushing of watersheds by storms which followed extended periods of low flow. For example, during a storm in November 1987, dissolved chloride in Furnace Fork increased from a pre-storm concentration of $334 \mathrm{mg} / \mathrm{L}$ to a peak concentration during the storm of more than $800 \mathrm{mg} / \mathrm{L}$. Bromide during this same event increased from 2.3 to $6.1 \mathrm{mg} / \mathrm{L}$.

Unlike the calcium-bicarbonate to sodium-bicarbonate water of the control watershed (Cat Creek), water from Big Sinking Creek was a sodium chloride type throughout the period April 1987 through March 1989 (fig. 9). Bromide in excess of 0.3 percent of the total anionic species was present in Big Sinking Creek about 80 percent of the time (fig. 10). The source of the sodium, chloride, and bromide was most 1ikely from discharge of oil-production brines because the predominant ionic constituents observed in separator discharges of these watersheds were sodium and chloride (table 3 ), and bromide composition in excess of 0.3 percent has been determined in these waters. Less oil production occurs in Furnace Fork than in Big Sinking Creek and the water type of Furnace Fork varies, sometimes resembling that of Cat Creek and at other times resembling that of Big Sinking Creek. Furnace Fork water was similar to that of Cat Creek when values of specific conductance were small (less than $600 \mu \mathrm{S} / \mathrm{cm})$, but similar to water of Big Sinking Creek when specific conductance values were large (greater than $1,300 \mu \mathrm{S} / \mathrm{cm}$ ) (fig. 9). Krieger 
and Hendrickson (1960) in their study of the Green River described this same effect of oil-production brines in converting a calcium bicarbonate type water to one of the sodium chloride type.

Average annual yields of bromide, chloride, sodium, and strontium were greater from the oil-production watersheds than from the control watershed (table 5). The predominant dissolved constituents transported from both the Cat Creek and Furnace Fork watersheds were calcium and bicarbonate, but the yields of bromide, chloride, sodium, and strontium were two to three times greater from the Furnace Fork watershed than from the Cat Creek watershed. Sodium and chloride were the predominant dissolved constituents transported from the Big Sinking Creek watershed. The yields of bromide, chloride, sodium, and strontium from the Big Sinking Creek watershed were at least 10 times greater than yields from the Cat Creek watershed.

The northern three catchment areas of the Furnace Fork watershed (Needmore Hollow, Upper Furnace Fork, and Unnamed Hollow) contain about 300 oil wells, but only about 30 are in the southern three catchment areas (Crowe, Stewart, and Shular hollows) (fig. 2). Based on monthly measurements, chloride and bromide yields from each of the northern three catchment areas were consistently much greater than from any of the southern three catchment areas, and summed together, the northern catchment areas contributed from 20 to more than 100 times the constituent load to the stream system than the southern catchment areas. Chloride concentrations in monthly samples of water from the northern catchment areas ranged from 9.6 to $3,100 \mathrm{mg} / \mathrm{L}$ (median, 155 $\mathrm{mg} / \mathrm{L}$ ), and bromide ranged from less than 0.01 to $24 \mathrm{mg} / \mathrm{L}$ (median, $0.9 \mathrm{mg} / \mathrm{L}$ ). In water sampled monthly from the southern three catchment areas, chloride ranged from 2.1 to $30 \mathrm{mg} / 1$ (median, $8.8 \mathrm{mg} / \mathrm{L}$ ), and bromide ranged from $<0.01$ to $0.09 \mathrm{mg} / \mathrm{L}$ (median, $0.01 \mathrm{mg} / \mathrm{L}$ ).

The average daily chloride loads of Furnace Fork and Big Sinking Creek were much larger than that allowed by State permits for discharge of oilproduction brines to streams. Although it is uncertain if these excess loads were due to brine releases in excess of permitted levels or due to some other source such as flowing abandoned wells, it is apparent that most of this chloride load resulted from oil-production activities. This assessment is based on comparison of the chloride yields from the Furnace Fork and Big Sinking Creek watersheds with that considered natural as defined by the chloride yield of the non-production Cat Creek watershed (table 5). The average non-natural chloride load of Big Sinking Creek was approximately 34,000 pounds per day, but a total chloride discharge of only slightly more than 2,000 pounds per day is permitted in the watershed (Kentucky Division of Water, written communication, 1990). The average non-natural chloride load of Furnace Fork was approximately 1,600 pounds per day, but a chloride discharge of only 12 pounds per day is permitted in the watershed (Kentucky Division of Water, written communication, 1990).

Based on specific conductance records during storm events, it appears that dissolved constituents are flushed from the drainage systems very rapidly when the flow regime is high (generally fall through winter) (fig. 11). The constituent transport mechanism during high-flow storm events is belleved to reflect a quick first-flush and dilution response to discharge and minimum constituent concentrations occur coincident with or shortly after the time of 
peak discharge. The constituent transport mechanism during low-flow storm events (generally spring through summer) is believed to represent a slower or less complete response to discharge than during high flow due to longer travel times. Peak concentrations during the low-flow storms may lag behind the peak flow by as much as a day or more (fig. 11).

Dissolved constituent transport from both the oil production watersheds and the non-production watershed had a similar non-uniform loading pattern which indicated intermittent release. During the low-flow summer and fall months, the total constituent loads from the six catchment areas upstream of the Furnace Fork gaging station often exceeded those at the gaging station. This indicates temporary storage in the hydrologic system possibly in the alluvium or shallow bedrock of the watershed. Assuming that oil production is somewhat constant, transport seems to be a function of both stream discharge and time since the system was flushed. Comparatively little constituent transport occurs during the low-flow summer and fall months, but greatest transport usually occurs following these periods due to flushing of the watersheds by initial high-flow season events (figs. 7 and 12).

Concentrations of organic substances in waters of the three watersheds studied were similar. Organic carbon concentrations in waters draining the oil-production watersheds was of interest because oil stains were observed along several ditches leading from separator tanks to the streams. The range of organic carbon concentrations of samples from the oil-production watersheds of Big Sinking Creek and Furnace Fork and samples from the non-oil-production watershed of Cat Creek were fairly similar (fig. 6). Further examination by gas chromatography/flame ionization detector (FID scan) screening of monthly samples obtained June 1987 to October 1988 could not detect appreciable differences in the quantities of organic substances among the waters of the three watersheds. Absence of large quantities of organic substances in water samples from the oil-production watersheds might be due to volatilization of such compounds or their attachment to solid phase media, such as bottom material.

The Kentucky criteria of $5 \mu \mathrm{g} / \mathrm{L}$ phenols for protection of aquatic habitat was exceeded in Big Sinking Creek and Furnace Fork watersheds according to a 1989 study by Logan and others (1989). In that study, the phenols in six samples from the Big Sinking Creek watershed ranged from 11 to $28 \mu \mathrm{g} / \mathrm{L}$. Only a single sample was obtained from the Furnace Fork watershed, but its phenol concentration was reported as $210 \mu \mathrm{g} / \mathrm{L}$. Concentrations of phenols in water from two sites in Station Camp Creek, used as the control for the study by Logan and others (1989), were 29 and $34 \mu \mathrm{g} / \mathrm{L}$. Thus, phenols concentrations in excess of State criteria could not be directly attributed to oil-production activities.

Extent of 0il-Production Effects on Surface-Water Quality

Drainage from known oil-production areas had large concentrations of barium, bromide, chloride, sodium, or strontium during at least one synoptic sampling. Barium concentrations in excess of $100 \mu \mathrm{g} / \mathrm{L}$ were measured in some streams which drained oil-production watersheds during the 1987 synoptic sampling (fig. 13). Bromide concentrations of $0.01 \mathrm{mg} / \mathrm{L}$ or less were measured in at least 25 percent of the streams sampled during both synoptic surveys. 


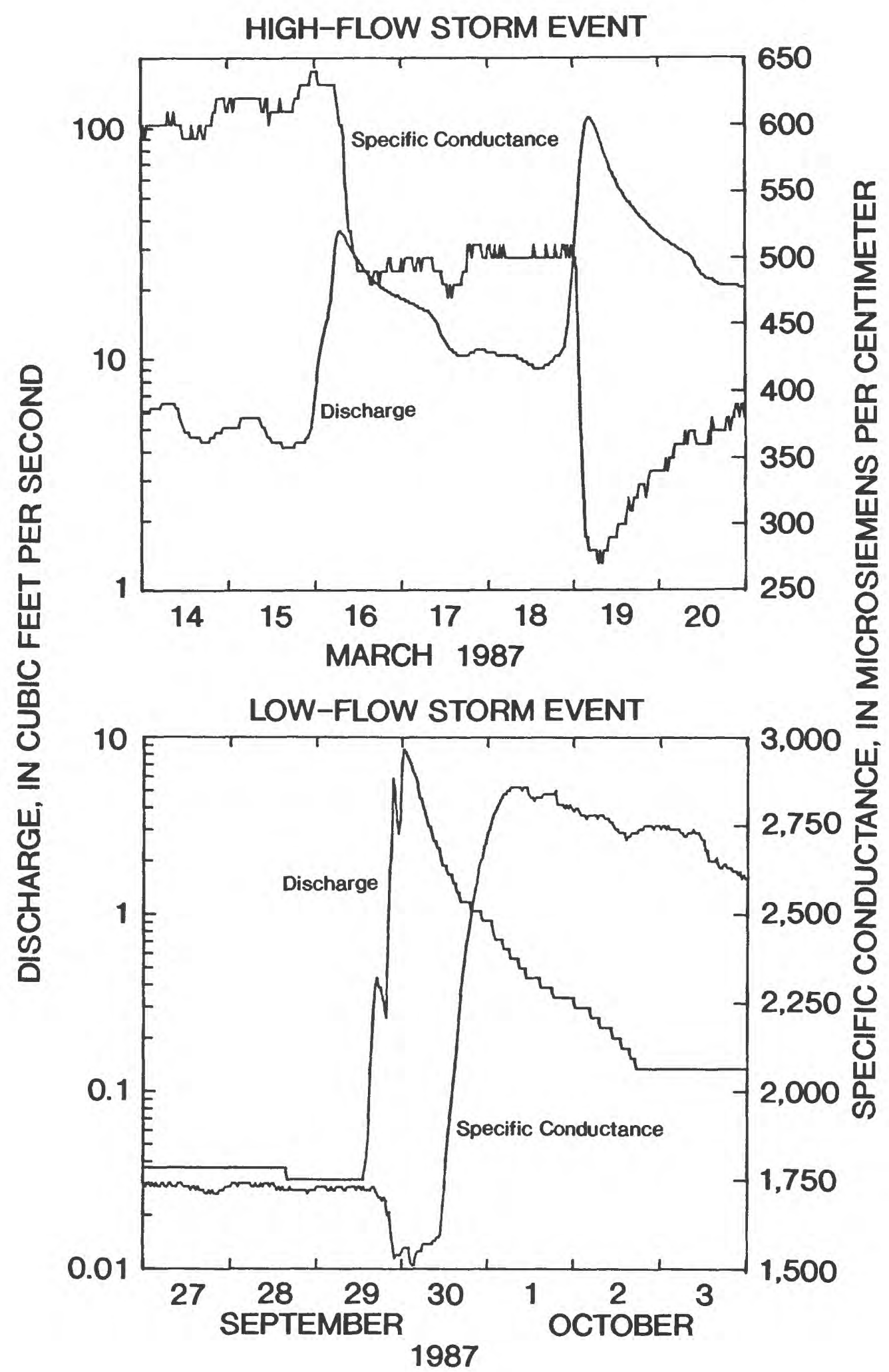

Figure 11.--Discharge and specific conductance in Furnace Fork, March 15-20, and September 27 to October 3, 1987. 
However, numerous streams in the oll-production areas of the Kentucky River basin had bromide concentrations in excess of $0.4 \mathrm{mg} / \mathrm{L}$ ( $\mathrm{fig} .14$ ). Greatest chloride and sodium concentrations were determined in oil-brine drainages, but many municipal wastewater discharges also had elevated levels of these constituents (figs. 15 and 16 ).

The areal extent of current oll-brine discharges includes streams tributary to the North and South Forks of the Kentucky River, the headwaters of Millers Creek including the Furnace Fork and Big Sinking Creek watersheds, and many streams tributary to the Middle and South Forks of the Red River. These drainages generally are in the upper and middle portions of the Kentucky River basin. Information available for this assessment included: (1) results of the two synoptic samplings in 1987 and 1988, (2) a reconnaissance study conducted by the Kentucky Geological Survey in May and June 1985 to assess the effects of oil-brine disposal in the area between the Red and Kentucky Rivers (Kentucky Geological Survey, written communication, 1986), and (3) information assembled by Bradfield and Porter (1990) which described stream reaches in the Kentucky River basin where the aquatic biota had been adversely affected by drainage from oll-production areas.

The low-flow synoptic samplings identifled increased concentrations of barium, bromide, chloride, sodium, and strontium in the mainstream of the Kentucky River downstream of river mile 270 (between Frozen Creek and Airdale) which was belleved to be due to drainage from oil-production areas (fig. 17). Because these constituents are highly conservative, downstream concentrations are slowly decreased by dilution from waters draining non-oil-production watersheds.

Bromide is of particular interest because of its possible role in the formation of trihalomethanes (THMs), which are thought to be carcinogenic. Trihalomethanes are generally formed during the disinfection of water supplies with chlorine. Brominated THMs can be produced as a result of bromide ions in the water being oxidized by aqueous chlorine to bromine which then reacts with organic substances to produce THMs. Because bromine is more reactive than chlorine, bromine substitutions can dramatically increase the total trihalomethane level (Viessman and Hammer, 1985). As a result of oxidation, naturally occurring organic substances in water supplies are halogenated, and THMs consisting mainly of chloroform $\left(\mathrm{CHCl}_{3}\right)$ dichlorobromomethane $\left(\mathrm{CHCl}_{2} \mathrm{Br}\right)$, chlorodibromomethane $\left(\mathrm{CHClBr}_{2}\right)$, and bromoform $\left(\mathrm{CHBr}_{3}\right)$ are produced (Pope, Arruda, and Fromm, 1988).

The largest concentrations of chloride and bromide in the Kentucky River at Lock 10 typically occur in the fall during the first period of significantly increased runoff following the dry late-summer months. This period corresponds in general to the time of first flushing of accumulated ionic constituents from the watersheds draining the oil-production areas. Chloride concentration in the Kentucky River at Lock 10 reached $270 \mathrm{mg} / \mathrm{L}$ and bromide concentration reached $1.8 \mathrm{mg} / \mathrm{L}$ in early November 1984, based on daily records since 1982 of the Kentucky American Water Company for samples collected 8.2 miles downstream from Lock 10 (river mile 168.2) (table 6). Accuracy of these data was verified by comparison to chloride data obtained by the U.S. Geological Survey upstream at Lock 10. Regression between dissolved 

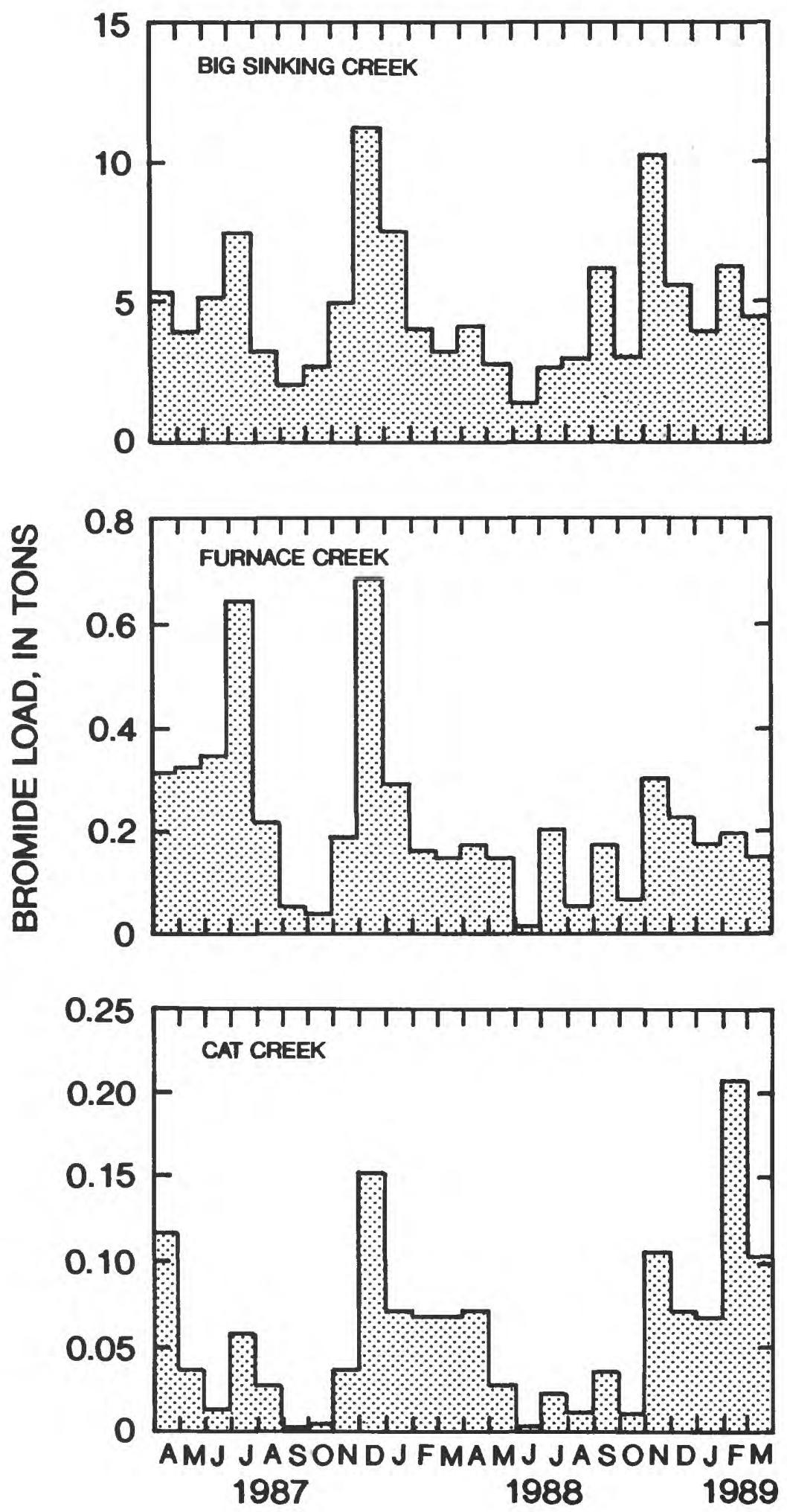

Figure 12.--Monthly bromide load of Big Sinking Creek, Furnace Fork, and Cat Creek, April 1987 to March 1989. 


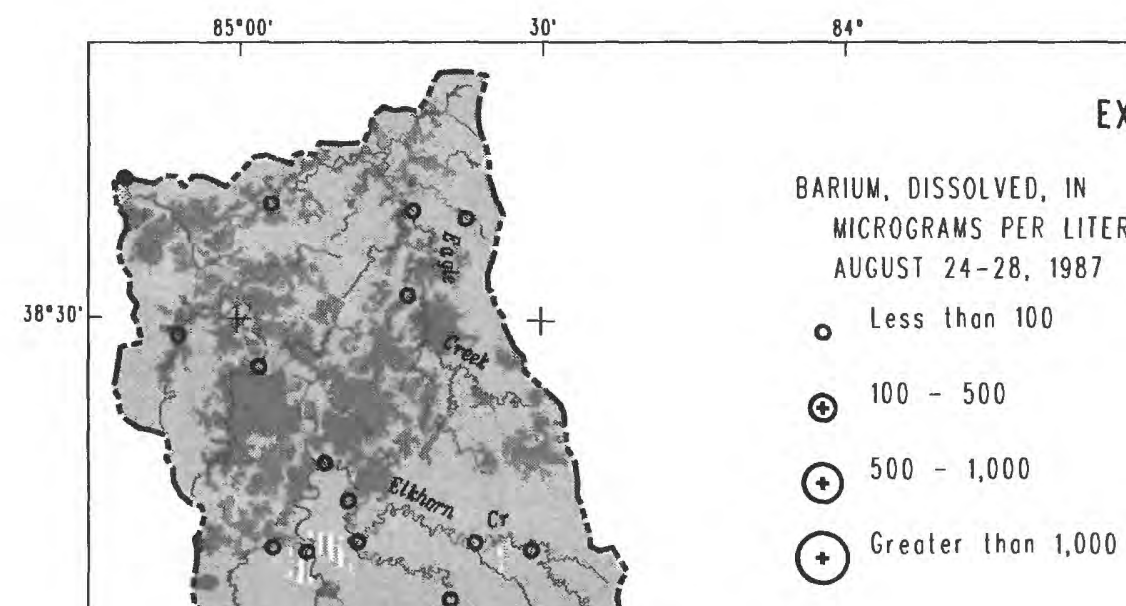

$83^{\circ} 00^{\circ}$

\section{EXPLANATION}

ARIUM, DISSOLVED, IN

GENERALIZED LAND COVER IICROGRAMS PER LITER, AND RESOURCE AREAS

AUGUST $24-28,1987$

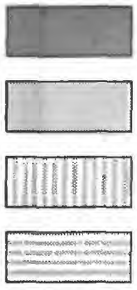

Forest

Agriculture

Urbon

Principol cool production area

Dil production area

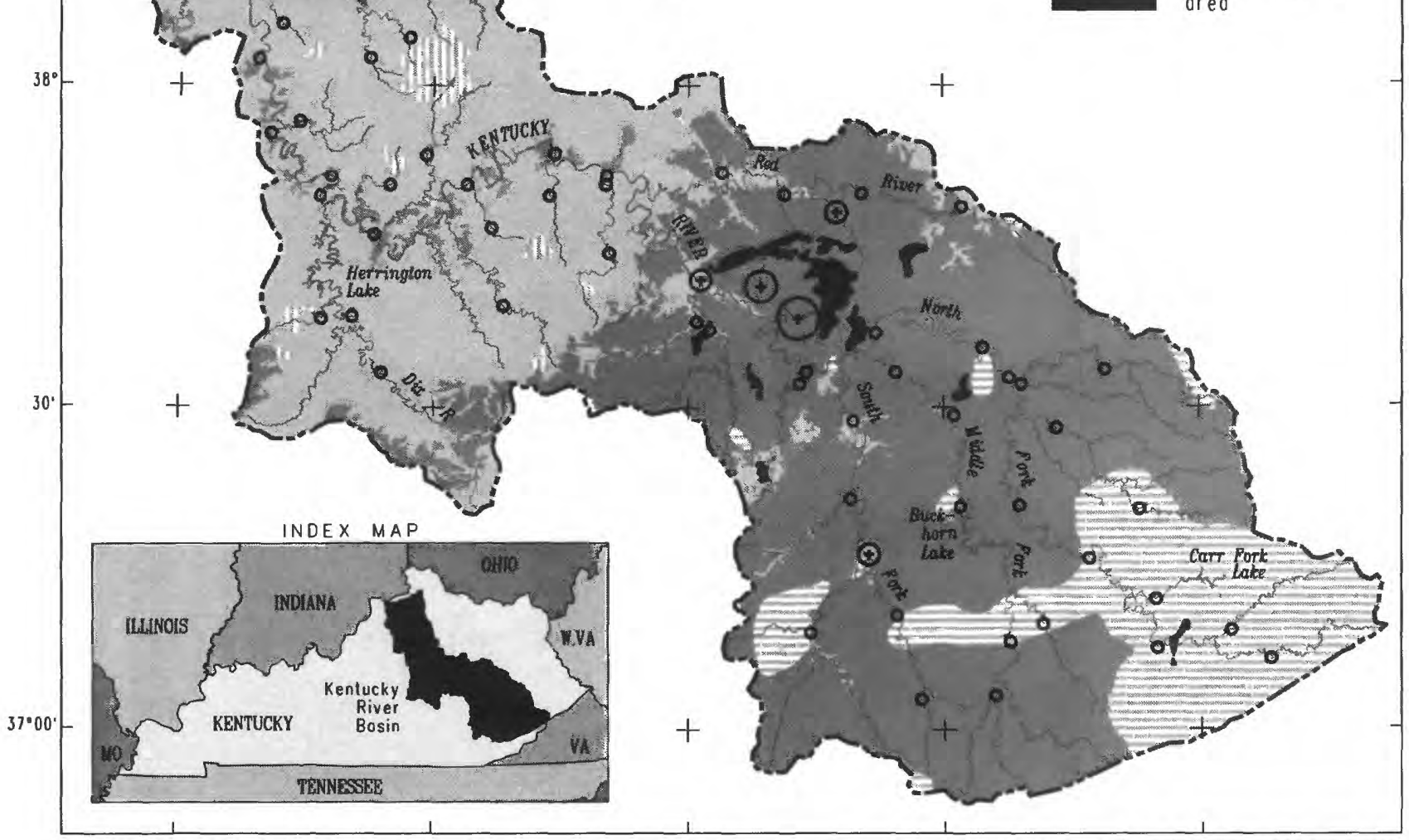

Bose from U.S. Geologicol Survey

Lond cover modified from U.S. Geologicol Survey Digital line grophs from 1:100,000 mops Digilal dala from 1:250,000 maps Cool produclion modilied from Johnson ond others (1962) oil production modified from Wilson and Sution (1973)

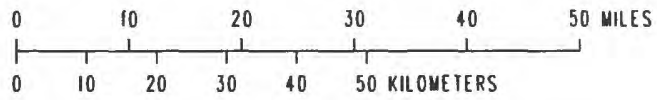

Figure 13.--Dissolved borium concentrations of surfoce woter synoptic sompling sites in the Kentucky River bosin, August 24-28, 1987. 


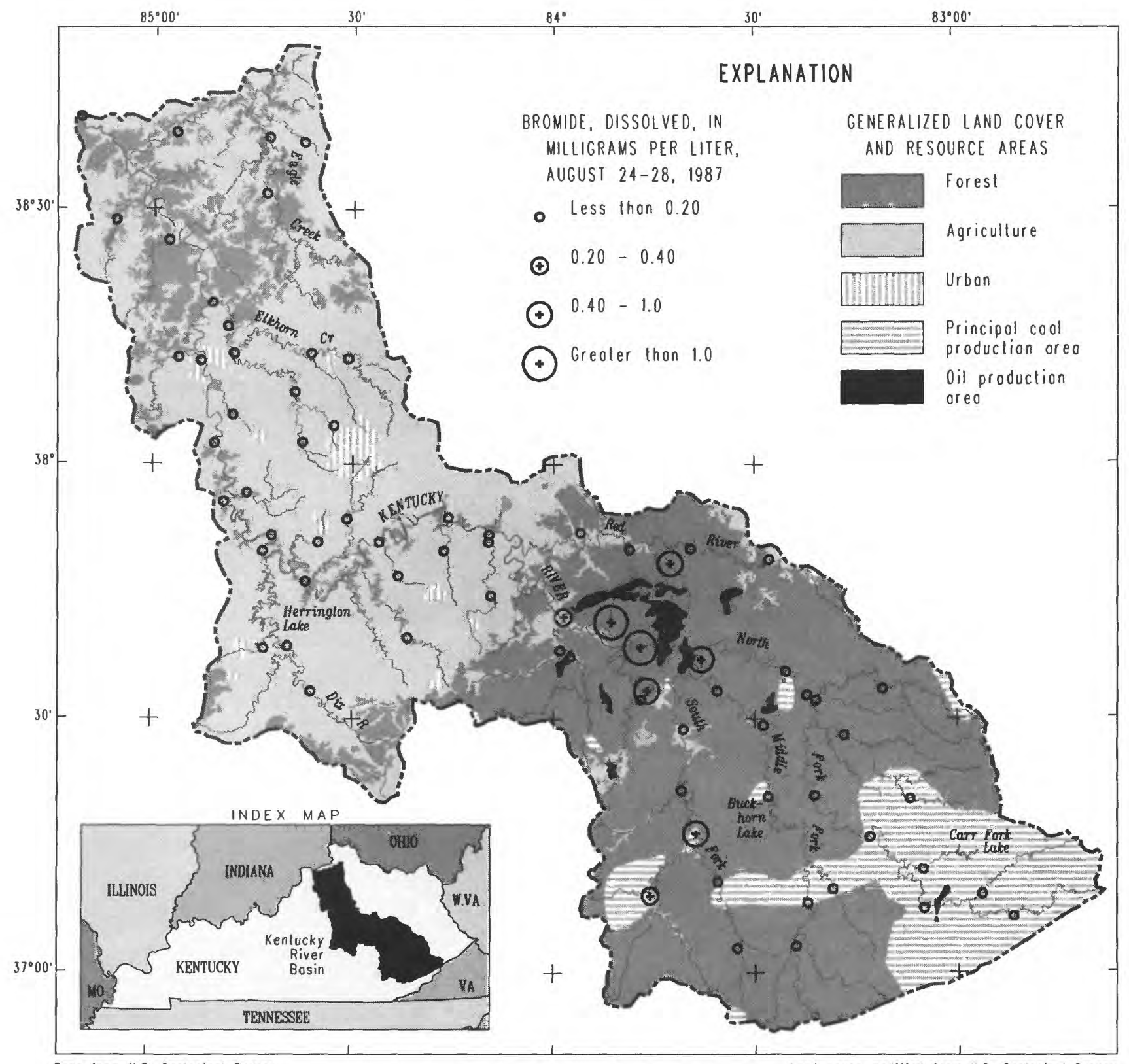

Bose from U.S. Geological Survey

Digital line grophs from 1:100,000 mops

Land cover modilied from U.S. Geological Survey Digital data from 1:250,000 mops Cool production modilied from Johnson and others (1962) oil produclion modified from wilson and sutton (1973)

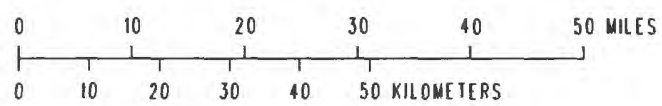

Figure 14.--Dissolved bromide concentrotions ot surface woter synoptic sompling sites in the Kentucky River bosin, August 24-28, 1987. 


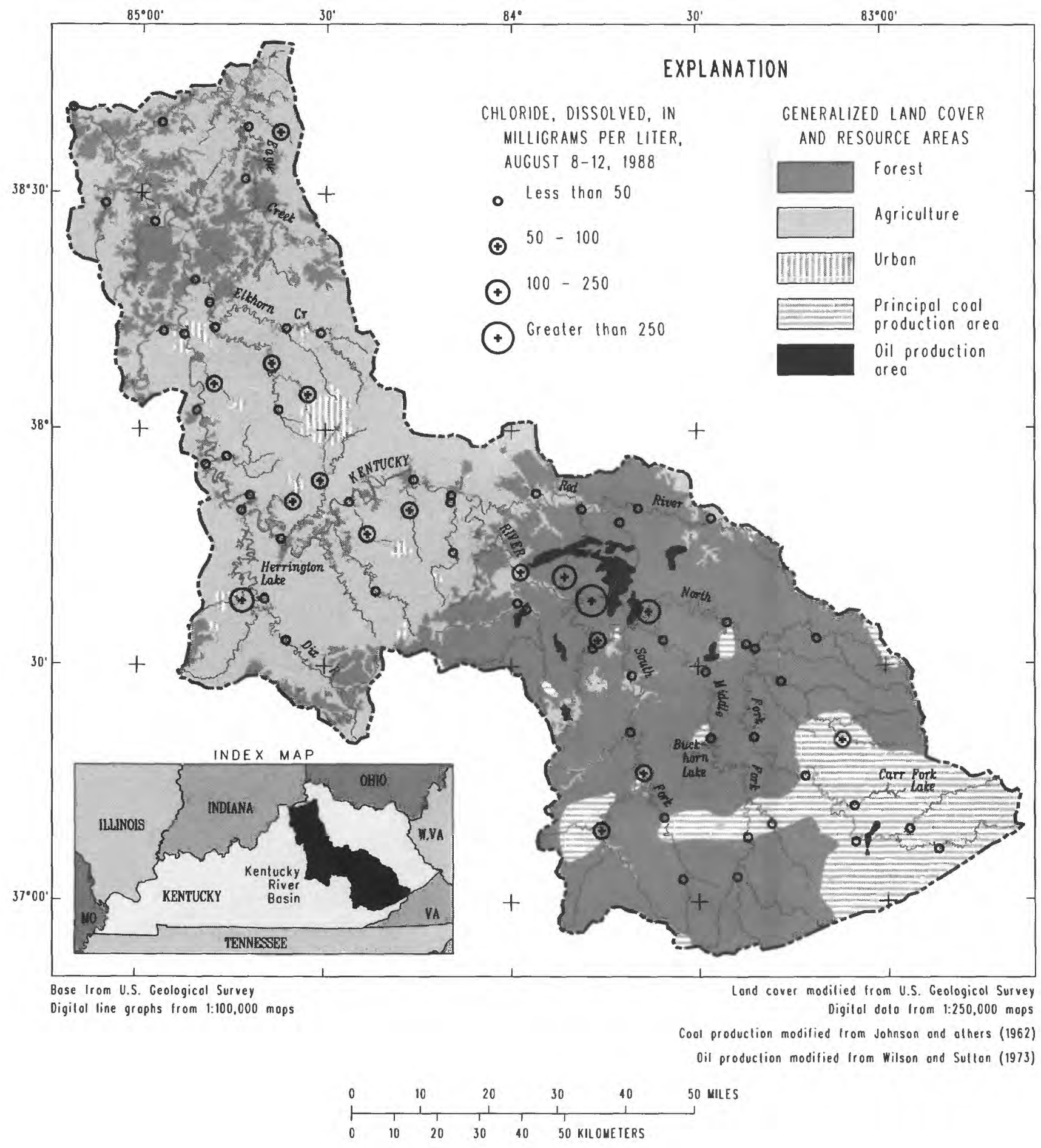

Figure 15.--Dissolved chloride concentrations ot surfoce woter synoptic sampling sites in the Kentucky River bosin. August 8-12, 1988. 


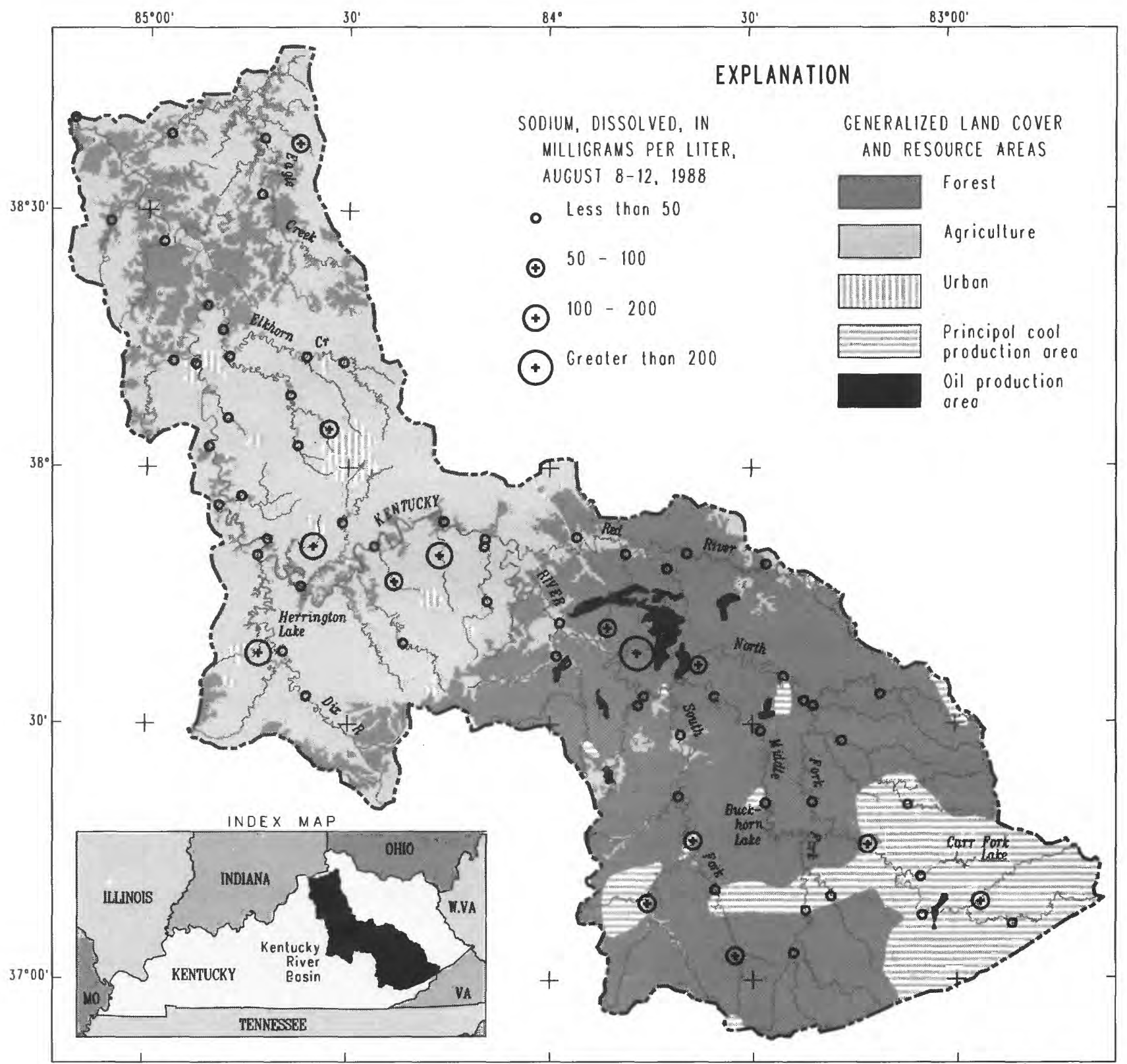

Bose Irom U.S. Geologicol Survey

Lond cover modilied from U.S. Geological Survey Digitol line grophs from 1:100,000 mops Digitol dolo from 1:250,000 mops Cool production modified from Johnson ond others (1962) Oil production modilied from Wilson ond Sutton (1973)

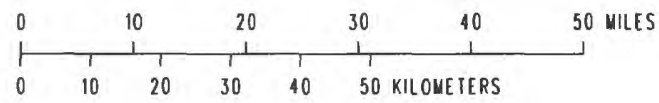

Figure 16.--Dissolved sodium concentrations at surface water synoptic sompling sites in the Kentucky River bosin. August 8-12, 1988. 

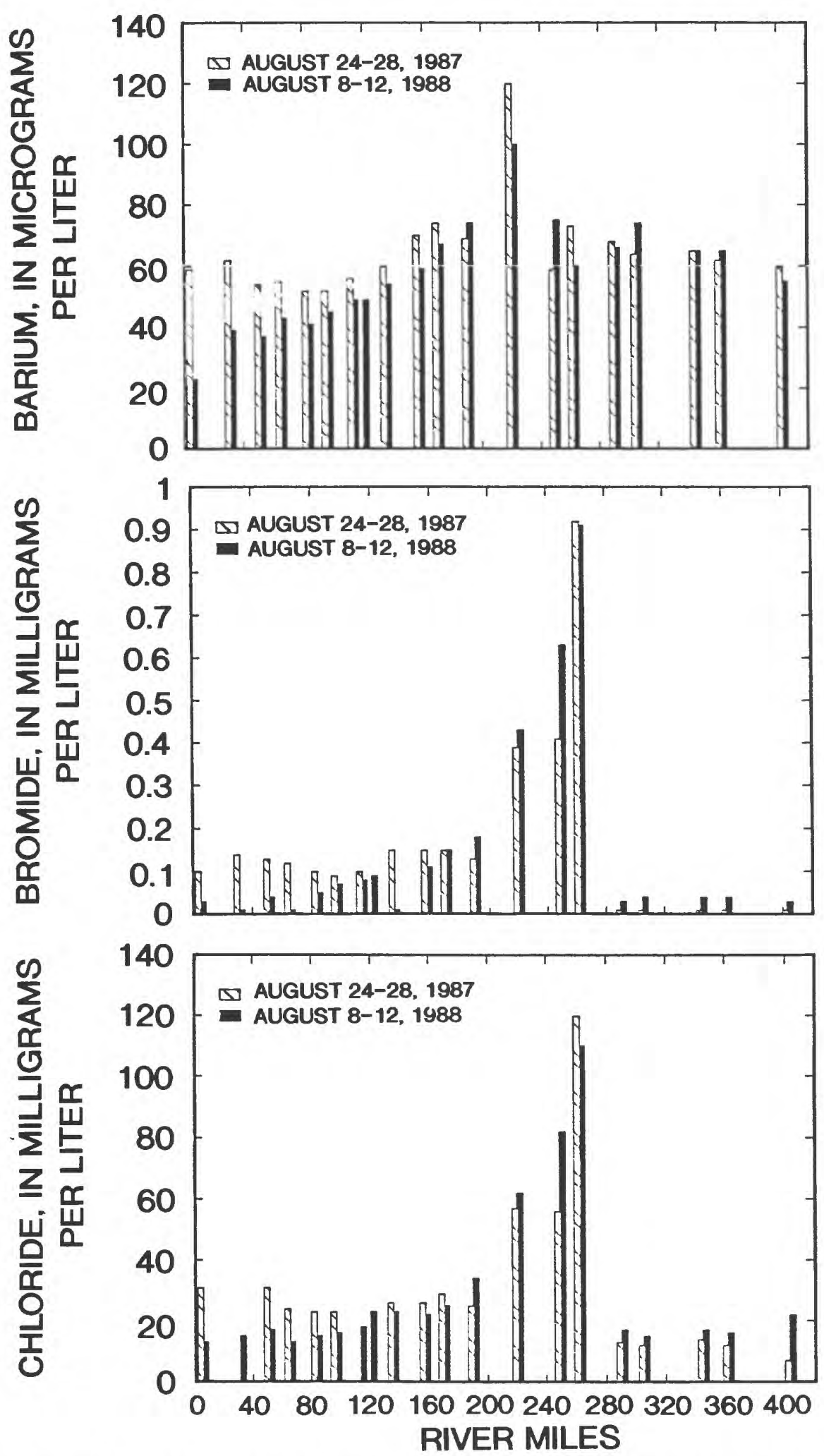

Figure 17.--Dissolved barium, bromide, and chloride concentrations in the main stem of the Kentucky River, August 24-28, 1987, and August 8-12, 1988. 
chloride concentrations determined by the U.S. Geological Survey laboratory for 29 samples from Lock 10 and concentrations from the Kentucky American Water Company analyses, with adjustments for travel time between the sites, explained 95 percent of the variability with a coefficient of variation of 16 percent. In addition, regression between dissolved chloride concentrations determined by the Kentucky American Water Company and dissolved bromide concentrations obtained by the U.S. Geological Survey explained 93 percent of the variability with a coefficient of variation of 28 percent. This relation between chloride and bromide was used in conjunction with the daily record of chloride to synthesize daily bromide record at Lock 10 (table 6).

Monthly transport of chloride and bromide in the Kentucky River at Lock 10 (fig. 18) had a non-uniform pattern similar to that of bromide transport from Cat Creek, Furnace Fork, and Big Sinking Creek (fig. 12). Comparatively little constituent transport occurred during the low-flow summer and fall months. The greatest loads were generally transported in the winter high-flow periods. At times, bromide transport exceeded 50,000 pounds (25 tons) per day and chloride transport exceeded $8,000,000$ pounds $(4,000$ tons) per day during November 1984, October 1985, and February 1989 (table 6). Average annual dissolved chloride and bromide loads of the Kentucky River at Lock 10 for the period 1982-88 were approximately 90,500 and 399 tons, respectively. Road salt usage and atmospheric deposition could account for only about 15 percent of the chloride load in the Kentucky River at Lock 10 (Smoot and others, 1990). Chloride inputs from wastewater discharges were unknown. No major source of bromide other than discharge of oil production waters is known to exist in the Kentucky River basin.

Oil-production watersheds contribute a large percentage of the bromide and chloride loads of the Kentucky River. During the period April 1987 to March 1989, the average annual chloride and bromide loads in the Kentucky River at Lock 10 were approximately 72,600 tons and 265 tons, respectively. Big Sinking Creek and Furnace Fork drain only 0.84 percent of the Kentucky River basin drainage above Lock 10, however the combined average annual chloride load of Big Sinking Creek and Furnace Fork during this period was 7,080 tons, or 10.3 percent of the load at Lock 10. The combined average annual bromide load of Big Sinking Creek and Furnace Fork was 59.6 tons, or 22.5 percent of the load in the Kentucky River at Lock 10.

The yields of dissolved chloride and bromide from the control watershed (Cat Creek) of 19.3 and 0.08 tons $/ \mathrm{mi}^{2}$, respectively, were slightly larger than average for the Kentucky River basin during the study period. The average annual chloride yield of the Kentucky River at Lock 10 was 18.4 tons $/ \mathrm{mi}^{2}$; and the total average annual bromide yield was about 0.07 tons $/ \mathrm{mi}^{2}$, of which approximately 0.01 tons $/ \mathrm{mi}^{2}$ is estimated to be from natural background sources. Cat Creek, which drains 0.21 percent of the area above Lock 10 , had an average annual chloride load of only 160 tons, or 0.22 percent of the chloride load in the Kentucky River at Lock 10 during April 1987 to March 1989. During this period, Cat Creek had an average annual bromide load of 0.70 tons, or 0.26 percent of the total bromide load at Lock 10 . 
Table 6.--Concentration and load estimates of bromide and chloride

in the Kentucky River at Lock 10 , January 1982 to April 1989

[mg/L, milligrams per liter]

\begin{tabular}{|c|c|c|c|c|c|c|c|c|}
\hline \multirow{2}{*}{ Year } & \multirow[b]{2}{*}{ Month } & \multicolumn{3}{|c|}{ Daily concentration estimates } & \multicolumn{3}{|c|}{ Daily load estimates } & \multirow[b]{2}{*}{$\begin{array}{l}\text { Total } \\
\text { (tons) }\end{array}$} \\
\hline & & $\begin{array}{l}\text { Minimum } \\
(\mathrm{mg} / \mathrm{L})\end{array}$ & $\begin{array}{c}\text { Mean } \\
(\mathrm{mg} / \mathrm{L})\end{array}$ & $\begin{array}{c}\text { Maximum } \\
(\mathrm{mz} / \mathrm{L})\end{array}$ & $\begin{array}{l}\text { Minimum } \\
\text { (pounds) }\end{array}$ & $\begin{array}{l}\text { Mean } \\
\text { (Founds) }\end{array}$ & $\begin{array}{l}\text { Maximum } \\
\text { (founds) }\end{array}$ & \\
\hline \multicolumn{9}{|c|}{ Bromide, dissolved } \\
\hline 1982 & 1 & 0.022 & 0.057 & 0.11 & 477 & 3,440 & 19,400 & 53.3 \\
\hline 1982 & 2 & .005 & .038 & .12 & 220 & 2,120 & 6,810 & 29.7 \\
\hline 1982 & 3 & .022 & .060 & .091 & 940 & 3,410 & 10,500 & 52.9 \\
\hline 1982 & 4 & .029 & .069 & .13 & 701 & 1,710 & 5,070 & 25.7 \\
\hline 1982 & 5 & .049 & .13 & .34 & 274 & 1,380 & 9,330 & 21.4 \\
\hline 1982 & 6 & .049 & .083 & .13 & 328 & 2,120 & 10,200 & 31.8 \\
\hline 1982 & 7 & .091 & .13 & .27 & 208 & 531 & 1,300 & 8.24 \\
\hline 1982 & 8 & .11 & .28 & .71 & 267 & 1,380 & 8,910 & 21.4 \\
\hline 1982 & 9 & .070 & .15 & .37 & 191 & 1,950 & 13,000 & 29.2 \\
\hline 1982 & 10 & .036 & .27 & .77 & 90.6 & 959 & 2,960 & 14.9 \\
\hline 1982 & 11 & .098 & .24 & .91 & 565 & 2,720 & 6,930 & 40.8 \\
\hline 1982 & 12 & .049 & .085 & .16 & 886 & 3,530 & 12,800 & 54.8 \\
\hline 1983 & 1 & .029 & .076 & .14 & 495 & 1,330 & 7,070 & 20.6 \\
\hline 1983 & 2 & .015 & .049 & .14 & 628 & 2,110 & 9,670 & 29.5 \\
\hline 1983 & 3 & .070 & .099 & .16 & 1,190 & 1,900 & 4,270 & 29.4 \\
\hline 1983 & 4 & .008 & .062 & .12 & 458 & 2,290 & 8,760 & 34.4 \\
\hline 1983 & 5 & 0 & .022 & .056 & 0 & 2,430 & 10,400 & 37.7 \\
\hline 1983 & 6 & .029 & .060 & .17 & 165 & 1,060 & 8,010 & 15.9 \\
\hline 1983 & 7 & .084 & .17 & .59 & 166 & 836 & 4,750 & 13.0 \\
\hline 1983 & 8 & .11 & .13 & .16 & 131 & 252 & 838 & 3.90 \\
\hline 1983 & 9 & .091 & .14 & .22 & 95.0 & 197 & 333 & 2.96 \\
\hline 1983 & 10 & .18 & .29 & .54 & 339 & 920 & 2,860 & 14.3 \\
\hline 1983 & 11 & .24 & .37 & .71 & 561 & 2,020 & 8,590 & 30.3 \\
\hline 1983 & 12 & .084 & .17 & .29 & 735 & 2,020 & 5,950 & 31.3 \\
\hline 1984 & 1 & .084 & .18 & .33 & 859 & 2,090 & 6,550 & 32.4 \\
\hline 1984 & 2 & .029 & .085 & .13 & 511 & 2,470 & 12,100 & 35.8 \\
\hline 1984 & 3 & .022 & .055 & .11 & 728 & 2,870 & 9,680 & 44.6 \\
\hline 1984 & 4 & & .042 & .098 & 0 & 2,660 & 13.700 & 39.9 \\
\hline 1984 & 5 & 0 & .028 & .070 & 0 & 1,360 & 12,100 & 21.1 \\
\hline 1984 & 6 & .042 & .096 & .23 & 157 & 471 & 1,710 & 7.07 \\
\hline 1984 & 7 & .11 & .21 & .34 & 312 & 1,030 & 2,730 & 16.0 \\
\hline 1984 & 8 & .13 & .22 & .28 & 218 & 446 & 1,070 & 6.91 \\
\hline 1984 & 9 & .24 & .27 & 31 & 184 & 258 & 391 & 3.87 \\
\hline 1984 & 10 & .21 & .31 & .77 & 194 & 1,890 & 10,300 & 29.3 \\
\hline 1984 & 11 & .022 & .59 & 1.8 & 1,050 & 9,570 & 56,400 & 144 \\
\hline 1984 & 12 & .056 & .17 & .36 & 1,430 & 6,280 & 26,000 & 97.3 \\
\hline 1985 & 1 & .049 & .11 & .20 & 1,280 & 3,060 & 10,100 & 47.4 \\
\hline 1985 & 2 & .029 & .070 & .19 & 1,650 & 6,000 & 24,200 & 84.1 \\
\hline 1985 & 3 & .049 & .12 & .25 & 1,490 & 4,310 & 13,200 & 66.8 \\
\hline 1985 & 4 & .084 & .14 & .20 & 864 & 2,500 & 8,370 & 37.6 \\
\hline 1985 & 5 & .15 & .27 & .42 & 989 & 4,010 & 19,500 & 62.2 \\
\hline 1985 & 6 & .11 & .18 & .37 & 267 & 3,440 & 26,900 & 51.6 \\
\hline 1985 & 7 & .11 & .29 & .55 & 233 & 1,640 & 6,080 & 25.4 \\
\hline 1985 & 8 & .11 & .29 & .91 & 237 & 4,840 & 29,800 & 75.0 \\
\hline 1985 & 9 & .42 & .63 & .91 & 567 & 2,270 & 14,200 & 34.0 \\
\hline 1985 & 10 & .35 & .64 & 1.6 & 574 & 6,290 & 58,900 & 97.5 \\
\hline 1985 & 11 & .098 & .25 & .77 & 1,240 & 9,040 & 46,200 & 136 \\
\hline 1985 & 12 & .036 & .11 & .20 & 1,030 & 3,080 & 14,600 & 47.7 \\
\hline 1986 & 1 & .14 & .25 & .42 & 792 & 3,250 & 8,650 & 50.4 \\
\hline 1986 & 2 & .032 & .081 & .18 & 1,450 & 5,930 & 20,400 & 83.0 \\
\hline 1986 & 3 & .049 & .094 & .15 & 1,020 & 3,110 & 10,000 & 48.2 \\
\hline 1986 & 4 & .10 & .15 & .22 & 670 & 932 & 1,370 & 14.0 \\
\hline 1986 & 5 & .23 & .34 & .51 & 893 & 2,330 & 5,700 & 36.2 \\
\hline 1986 & 6 & .17 & .32 & .52 & 369 & 1,060 & 3,300 & 16.0 \\
\hline 1986 & 7 & .24 & .35 & .52 & 329 & 866 & 3,630 & 13.4 \\
\hline 1986 & 8 & .31 & .34 & .44 & 223 & 480 & 1,130 & 7.44 \\
\hline 1986 & 9 & .44 & .56 & .71 & 577 & 2,690 & 7,730 & 40.4 \\
\hline 1986 & 10 & .16 & .32 & .57 & 644 & 1,450 & 3,650 & 22.5 \\
\hline 1986 & 11 & .015 & .12 & .39 & 605 & 3,680 & 25,200 & 55.2 \\
\hline 1986 & 12 & .018 & .063 & .12 & 518 & 2,620 & 17,200 & 40.6 \\
\hline 1987 & 1 & .008 & .069 & .15 & 151 & 1,610 & 14,200 & 24.9 \\
\hline 1987 & 2 & .015 & .041 & .10 & 390 & 2,070 & 5,470 & 29.0 \\
\hline 1987 & 3 & .001 & .035 & .19 & 63.3 & 1,370 & 6,180 & 21.2 \\
\hline 1987 & 4 & & .016 & .063 & 0 & 923 & 5,720 & 13.8 \\
\hline 1987 & 5 & .015 & .058 & .14 & 186 & 770 & 1,520 & 11.9 \\
\hline 1987 & 6 & .049 & .11 & .20 & 360 & 684 & 1,410 & 10.3 \\
\hline 1987 & 7 & .077 & .15 & .22 & 268 & 1,360 & 6,680 & 21.0 \\
\hline 1987 & 8 & .12 & .15 & .17 & 128 & 239 & 427 & 3.71 \\
\hline 1987 & 9 & .084 & .18 & .30 & 91.1 & 223 & 589 & 3.35 \\
\hline 1987 & 10 & .19 & .27 & .40 & 181 & 368 & 628 & 5.70 \\
\hline 1987 & 11 & .039 & .44 & .62 & 77.5 & 1,080 & 2,250 & 16.3 \\
\hline 1987 & 12 & .032 & .39 & .60 & 693 & 3,360 & 27,300 & 52.1 \\
\hline
\end{tabular}


Table 6. - Concentration and load estimates of bromide and chloride

in the Kentucky River at Lock 10, January 1982 to Apri1 1989--Continued

\begin{tabular}{|c|c|c|c|c|c|c|c|c|}
\hline \multirow[b]{2}{*}{ Year } & \multirow[b]{2}{*}{ Month } & \multirow{2}{*}{\multicolumn{3}{|c|}{$\begin{array}{l}\text { Daily concentration estimates } \\
\text { Minimum Mean Maximum }\end{array}$}} & \multicolumn{3}{|c|}{ Daily load estimates } & \\
\hline & & & & & $\begin{array}{l}\text { Minimum } \\
\text { (pounds) }\end{array}$ & $\begin{array}{l}\text { Mean } \\
\text { (pounds) }\end{array}$ & $\begin{array}{l}\text { Maximum } \\
\text { (pounds) }\end{array}$ & $\begin{array}{l}\text { Total } \\
\text { (tons) }\end{array}$ \\
\hline
\end{tabular}

Bromide, dissolved--Continued

\begin{tabular}{|c|c|c|c|c|c|c|c|c|}
\hline $\begin{array}{l}1988 \\
1988 \\
1988 \\
1988 \\
1988 \\
1988 \\
1988 \\
1988 \\
1988 \\
1988 \\
1988 \\
1988\end{array}$ & $\begin{array}{r}1 \\
2 \\
3 \\
4 \\
5 \\
6 \\
7 \\
8 \\
9 \\
10 \\
11 \\
12\end{array}$ & $\begin{array}{l}.011 \\
.025 \\
.077 \\
.001 \\
.015 \\
.063 \\
.084 \\
.13 \\
.19 \\
.17 \\
.015 \\
.022\end{array}$ & $\begin{array}{l}.059 \\
.064 \\
.13 \\
.059 \\
.063 \\
.12 \\
.13 \\
.17 \\
.27 \\
.38 \\
.19 \\
.084\end{array}$ & $\begin{array}{l}.094 \\
.11 \\
.19 \\
.15 \\
.17 \\
.50 \\
.16 \\
.23 \\
.41 \\
.51 \\
.50 \\
.13\end{array}$ & $\begin{array}{c}293 \\
383 \\
1,050 \\
113 \\
143 \\
74.8 \\
58.3 \\
111 \\
202 \\
360 \\
286 \\
511\end{array}$ & $\begin{array}{r}1,450 \\
1,310 \\
2,130 \\
1,740 \\
979 \\
184 \\
376 \\
245 \\
1,890 \\
563 \\
3,890 \\
2,530\end{array}$ & $\begin{array}{r}9,570 \\
3,590 \\
9,170 \\
15,100 \\
3,930 \\
1,360 \\
2,150 \\
669 \\
10,600 \\
1,120 \\
27,800 \\
16,300\end{array}$ & $\begin{array}{c}22.5 \\
19.0 \\
33.1 \\
26.1 \\
15.2 \\
2.76 \\
5.83 \\
3.81 \\
28.4 \\
8.73 \\
58.4 \\
39.2\end{array}$ \\
\hline $\begin{array}{l}1989 \\
1989 \\
1989 \\
1989\end{array}$ & $\begin{array}{l}1 \\
2 \\
3 \\
4\end{array}$ & $\begin{array}{ll}0 & \\
0 & \\
.001 \\
.001\end{array}$ & $\begin{array}{l}.062 \\
.039 \\
.017 \\
.030\end{array}$ & $\begin{array}{l}.54 \\
.31 \\
.049 \\
.063\end{array}$ & $\begin{array}{r}0 \\
0 \\
284 \\
48.3\end{array}$ & $\begin{array}{r}3,100 \\
4,440 \\
1,210 \\
879\end{array}$ & $\begin{array}{r}34,300 \\
54,000 \\
5,190 \\
2,650\end{array}$ & $\begin{array}{l}48.1 \\
62.2 \\
18.7 \\
13.2\end{array}$ \\
\hline
\end{tabular}

\section{Chloride, dissolved}

\begin{tabular}{|c|c|c|c|c|c|c|c|c|}
\hline $\begin{array}{l}1982 \\
1982 \\
1982 \\
1982 \\
1982 \\
1982 \\
1982 \\
1982 \\
1982 \\
1982 \\
1982 \\
1982\end{array}$ & $\begin{array}{r}1 \\
2 \\
3 \\
4 \\
5 \\
6 \\
7 \\
8 \\
9 \\
10 \\
11 \\
12\end{array}$ & $\begin{array}{l}11 \\
8.5 \\
11 \\
12 \\
15 \\
15 \\
21 \\
24 \\
18 \\
13 \\
22 \\
15\end{array}$ & $\begin{array}{l}16 \\
13 \\
16 \\
18 \\
26 \\
20 \\
27 \\
49 \\
30 \\
47 \\
43 \\
20\end{array}$ & $\begin{array}{r}24 \\
25 \\
21 \\
27 \\
57 \\
27 \\
47 \\
110 \\
61 \\
120 \\
140 \\
31\end{array}$ & $\begin{array}{r}128,000 \\
223,000 \\
301,000 \\
231,000 \\
57,900 \\
81,000 \\
44,000 \\
56,400 \\
49,000 \\
33,100 \\
96,800 \\
238,000\end{array}$ & $\begin{array}{l}956,000 \\
779,000 \\
997,000 \\
455,000 \\
275,000 \\
500,000 \\
110,000 \\
246,000 \\
369,000 \\
174,000 \\
502,000 \\
850,000\end{array}$ & $\begin{array}{r}4,170,000 \\
2,100,000 \\
2,820,000 \\
1,210,000 \\
1,570,000 \\
2,080,000 \\
300,000 \\
1,400,000 \\
2,160,000 \\
536,000 \\
1,230,000 \\
2,700,000\end{array}$ & $\begin{array}{r}14,800 \\
10,900 \\
15,500 \\
6,830 \\
4,270 \\
7,500 \\
1,710 \\
3,810 \\
5,540 \\
2,690 \\
7,530 \\
13,200\end{array}$ \\
\hline $\begin{array}{l}1983 \\
1983 \\
1983 \\
1983 \\
1983 \\
1983 \\
1983 \\
1983 \\
1983 \\
1983 \\
1983 \\
1983\end{array}$ & $\begin{array}{r}1 \\
2 \\
3 \\
4 \\
5 \\
6 \\
7 \\
8 \\
9 \\
10 \\
11 \\
12\end{array}$ & $\begin{array}{l}12 \\
10 \\
18 \\
9.0 \\
7.5 \\
12 \\
20 \\
23 \\
21 \\
34 \\
42 \\
20\end{array}$ & $\begin{array}{l}19 \\
15 \\
22 \\
17 \\
11 \\
17 \\
32 \\
26 \\
29 \\
50 \\
61 \\
32\end{array}$ & $\begin{array}{r}28 \\
28 \\
31 \\
25 \\
16 \\
32 \\
94 \\
31 \\
40 \\
86 \\
110 \\
50\end{array}$ & $\begin{array}{r}150,000 \\
219,000 \\
285,000 \\
225,000 \\
163,000 \\
44,500 \\
38,400 \\
27,600 \\
21,700 \\
60,500 \\
92,700 \\
155,000\end{array}$ & $\begin{array}{r}336,000 \\
618,000 \\
424,000 \\
642,000 \\
1,170,000 \\
281,000 \\
162,000 \\
52,200 \\
39,200 \\
157,000 \\
336,000 \\
386,000\end{array}$ & $\begin{array}{r}1,440,000 \\
1,950,000 \\
829,000 \\
2,030,000 \\
3,160,000 \\
1,540,000 \\
956,000 \\
174,000 \\
60,000 \\
460,000 \\
1,440,000 \\
1,050,000\end{array}$ & $\begin{array}{r}5,200 \\
8,650 \\
6,570 \\
9,640 \\
18,200 \\
4,210 \\
2,510 \\
810 \\
588 \\
2,440 \\
5,040 \\
5,980\end{array}$ \\
\hline $\begin{array}{l}1984 \\
1984 \\
1984 \\
1984 \\
1984 \\
1984 \\
1984 \\
1984 \\
1984 \\
1984 \\
1984 \\
1984\end{array}$ & $\begin{array}{r}1 \\
2 \\
3 \\
4 \\
5 \\
6 \\
7 \\
8 \\
9 \\
10 \\
11 \\
12\end{array}$ & $\begin{array}{l}20 \\
12 \\
11 \\
7.5 \\
6.0 \\
14 \\
23 \\
27 \\
42 \\
38 \\
11 \\
16\end{array}$ & $\begin{array}{l}34 \\
20 \\
16 \\
14 \\
12 \\
22 \\
38 \\
39 \\
48 \\
52 \\
94 \\
32\end{array}$ & $\begin{array}{r}56 \\
27 \\
23 \\
22 \\
18 \\
41 \\
57 \\
49 \\
52 \\
120 \\
270 \\
60\end{array}$ & $\begin{array}{r}160,000 \\
136,000 \\
240,000 \\
347,000 \\
112,000 \\
40,200 \\
55,100 \\
41,700 \\
32,100 \\
35,200 \\
242,000 \\
308,000\end{array}$ & $\begin{array}{r}415,000 \\
573,000 \\
854,000 \\
952,000 \\
953,000 \\
112,000 \\
193,000 \\
80,600 \\
44,900 \\
307,000 \\
1,610,000 \\
1,260,000\end{array}$ & $\begin{array}{r}1,250,000 \\
2,560,000 \\
2,750,000 \\
3,900,000 \\
3,100,000 \\
402,000 \\
510,000 \\
191,000 \\
67,800 \\
1,600,000 \\
9,090,000 \\
5,050,000\end{array}$ & $\begin{array}{r}6,430 \\
8,320 \\
13,200 \\
14,300 \\
14,800 \\
1,690 \\
2,990 \\
1,250 \\
673 \\
4,760 \\
24,200 \\
19,500\end{array}$ \\
\hline $\begin{array}{l}1985 \\
1985 \\
1985 \\
1985 \\
1985 \\
1985 \\
1985 \\
1985 \\
1985 \\
1985 \\
1985 \\
1985\end{array}$ & $\begin{array}{r}1 \\
2 \\
3 \\
4 \\
5 \\
6 \\
7 \\
8 \\
9 \\
10 \\
11 \\
12\end{array}$ & $\begin{array}{l}15 \\
12 \\
15 \\
20 \\
30 \\
23 \\
24 \\
23 \\
69 \\
59 \\
22 \\
13\end{array}$ & $\begin{array}{r}24 \\
18 \\
26 \\
28 \\
47 \\
34 \\
50 \\
50 \\
99 \\
100 \\
44 \\
23\end{array}$ & $\begin{array}{r}37 \\
35 \\
44 \\
37 \\
69 \\
62 \\
87 \\
140 \\
140 \\
240 \\
120 \\
37\end{array}$ & $\begin{array}{r}257,000 \\
549,000 \\
415,000 \\
177,000 \\
177,000 \\
54,500 \\
47,600 \\
52,200 \\
89,600 \\
94,900 \\
250,000 \\
226,000\end{array}$ & $\begin{array}{r}714,000 \\
1,490,000 \\
884,000 \\
513,000 \\
699,000 \\
613,000 \\
283,000 \\
812,000 \\
356,000 \\
967,000 \\
1,630,000 \\
705,000\end{array}$ & $\begin{array}{r}2,070,000 \\
4,530,000 \\
2,370,000 \\
1,580,000 \\
3,220,000 \\
4,470,000 \\
980,000 \\
4,720,000 \\
2,190,000 \\
8,830,000 \\
7,470,000 \\
2,680,000\end{array}$ & $\begin{array}{r}11,100 \\
20,900 \\
13,700 \\
7,700 \\
10,800 \\
9,190 \\
4,390 \\
12,600 \\
5,340 \\
15,000 \\
24,400 \\
10,900\end{array}$ \\
\hline
\end{tabular}


Table 6.--Concentration and load estimates of bromide and chloride in the Kentucky River at Lock 10, January 1982 to April 1989--Cont inued

\begin{tabular}{|c|c|c|c|c|c|c|c|c|}
\hline Year & Month & $\begin{array}{l}\text { Daily co } \\
\text { Minimam } \\
(\mathrm{mg} / \mathrm{L})\end{array}$ & $\begin{array}{l}\frac{\text { entratio }}{\text { Mean }} \\
(\mathrm{mg} / \mathrm{L})\end{array}$ & $\begin{array}{l}\frac{\text { estimates }}{\text { Maximum }} \\
(\mathrm{mg} / \mathrm{L})\end{array}$ & $\begin{array}{l}\text { Minimum } \\
\text { (pounds) }\end{array}$ & 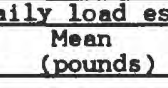 & $\begin{array}{l}\text { Imates } \\
\text { Maximum } \\
\text { (pounds) }\end{array}$ & $\begin{array}{l}\text { Total } \\
(\operatorname{tons})\end{array}$ \\
\hline \multicolumn{9}{|c|}{ Chloride, dissolved--Continued } \\
\hline $\begin{array}{l}1986 \\
1986 \\
1986 \\
1986 \\
1986 \\
1986 \\
1986 \\
1986 \\
1986 \\
1986 \\
1986 \\
1986\end{array}$ & $\begin{array}{r}1 \\
2 \\
3 \\
4 \\
5 \\
6 \\
7 \\
8 \\
9 \\
10 \\
11 \\
12\end{array}$ & $\begin{array}{l}28 \\
13 \\
15 \\
23 \\
41 \\
33 \\
43 \\
53 \\
71 \\
31 \\
10 \\
11\end{array}$ & $\begin{array}{l}45 \\
20 \\
22 \\
30 \\
58 \\
53 \\
59 \\
57 \\
89 \\
54 \\
25 \\
17\end{array}$ & $\begin{array}{r}68 \\
35 \\
30 \\
40 \\
82 \\
83 \\
83 \\
71 \\
110 \\
90 \\
65 \\
26\end{array}$ & $\begin{array}{r}146,000 \\
459,000 \\
235,000 \\
133,000 \\
158,000 \\
60,000 \\
56,700 \\
37,900 \\
93,900 \\
114,000 \\
135,000 \\
182,000\end{array}$ & $\begin{array}{r}559,000 \\
1,470,000 \\
695,000 \\
185,000 \\
390,000 \\
184,000 \\
145,000 \\
80,500 \\
429,000 \\
248,000 \\
968,000 \\
717,000\end{array}$ & $\begin{array}{r}1,450,000 \\
4,600,000 \\
2,020,000 \\
255,000 \\
926,000 \\
570,000 \\
602,000 \\
189,000 \\
1,210,000 \\
643,000 \\
5,320,000 \\
3,740,000\end{array}$ & $\begin{array}{r}8,660 \\
20,600 \\
10,800 \\
2,770 \\
6,040 \\
2,760 \\
2,240 \\
1,250 \\
6,430 \\
3,840 \\
14,500 \\
11,100\end{array}$ \\
\hline $\begin{array}{l}1987 \\
1987 \\
1987 \\
1987 \\
1987 \\
1987 \\
1987 \\
1987 \\
1987 \\
1987 \\
1987 \\
1987\end{array}$ & $\begin{array}{r}1 \\
2 \\
3 \\
4 \\
5 \\
6 \\
7 \\
8 \\
9 \\
10 \\
11 \\
12\end{array}$ & $\begin{array}{l}9.0 \\
10 \\
8.0 \\
10^{.40} \\
15 \\
19 \\
25 \\
20 \\
35 \\
14 \\
13\end{array}$ & $\begin{array}{l}18 \\
14 \\
13 \\
9.6 \\
16 \\
24 \\
29 \\
30 \\
34 \\
47 \\
72 \\
64\end{array}$ & $\begin{array}{l}29 \\
23 \\
35 \\
17 \\
28 \\
37 \\
40 \\
32 \\
51 \\
66 \\
98 \\
95\end{array}$ & $\begin{array}{r}137,000 \\
161,000 \\
141,000 \\
41,500 \\
84,900 \\
80,100 \\
49,900 \\
25,300 \\
21,700 \\
33,500 \\
24,500 \\
121,000\end{array}$ & $\begin{array}{r}435,000 \\
679,000 \\
558,000 \\
621,000 \\
225,000 \\
153,000 \\
267,000 \\
47,100 \\
42,100 \\
64,000 \\
176,000 \\
626,000\end{array}$ & $\begin{array}{r}2,820,000 \\
1,580,000 \\
2,030,000 \\
1,760,000 \\
478,000 \\
290,000 \\
1,230,000 \\
84,400 \\
101,000 \\
105,000 \\
363,000 \\
4,870,000\end{array}$ & $\begin{array}{r}6,730 \\
9,500 \\
8,650 \\
9,310 \\
3,490 \\
2,300 \\
4,150 \\
730 \\
632 \\
993 \\
2,640 \\
9,700\end{array}$ \\
\hline $\begin{array}{l}1988 \\
1988 \\
1988 \\
1988 \\
1988 \\
1988 \\
1988 \\
1988 \\
1988 \\
1988 \\
1988 \\
1988\end{array}$ & $\begin{array}{r}1 \\
2 \\
3 \\
4 \\
5 \\
6 \\
7 \\
8 \\
9 \\
10 \\
11 \\
12\end{array}$ & $\begin{array}{l}9.5 \\
12 \\
19 \\
8.0 \\
10 \\
17 \\
20 \\
26 \\
36 \\
33 \\
10 \\
11\end{array}$ & $\begin{array}{l}16 \\
17 \\
26 \\
16 \\
17 \\
25 \\
26 \\
33 \\
46 \\
63 \\
35 \\
20\end{array}$ & $\begin{array}{l}22 \\
23 \\
35 \\
30 \\
32 \\
80 \\
31 \\
41 \\
68 \\
82 \\
80 \\
27\end{array}$ & $\begin{array}{r}83,500 \\
126,000 \\
217,000 \\
148,000 \\
70,700 \\
16,900 \\
13,900 \\
21,200 \\
36,000 \\
65,500 \\
98,700 \\
121,000\end{array}$ & $\begin{array}{r}438,000 \\
354,000 \\
441,000 \\
500,000 \\
245,000 \\
37,900 \\
75,600 \\
46,800 \\
322,000 \\
94,100 \\
824,000 \\
658,000\end{array}$ & $\begin{array}{r}2,580,000 \\
871,000 \\
1,760,000 \\
3,200,000 \\
896,000 \\
218,000 \\
416,000 \\
129,000 \\
1,740,000 \\
185,000 \\
5,600,000 \\
3,890,000\end{array}$ & $\begin{array}{r}6,780 \\
5,140 \\
6,840 \\
7,490 \\
3,790 \\
568 \\
1,170 \\
725 \\
4,830 \\
1,460 \\
12,400 \\
10,200\end{array}$ \\
\hline $\begin{array}{l}1989 \\
1989 \\
1989 \\
1989\end{array}$ & $\begin{array}{l}1 \\
2 \\
3 \\
4\end{array}$ & $\begin{array}{l}5.0 \\
7.0 \\
8.0 \\
8.0\end{array}$ & $\begin{array}{l}17 \\
14 \\
10 \\
12\end{array}$ & $\begin{array}{l}86 \\
52 \\
15 \\
17\end{array}$ & $\begin{array}{l}172,000 \\
248,000 \\
288,000 \\
128,000\end{array}$ & $\begin{array}{r}865,000 \\
1,700,000 \\
818,000 \\
401,000\end{array}$ & $\begin{array}{l}5,470,000 \\
9,230,000 \\
2,610,000 \\
1,280,000\end{array}$ & $\begin{array}{r}13,400 \\
23,800 \\
12,700 \\
6,020\end{array}$ \\
\hline
\end{tabular}



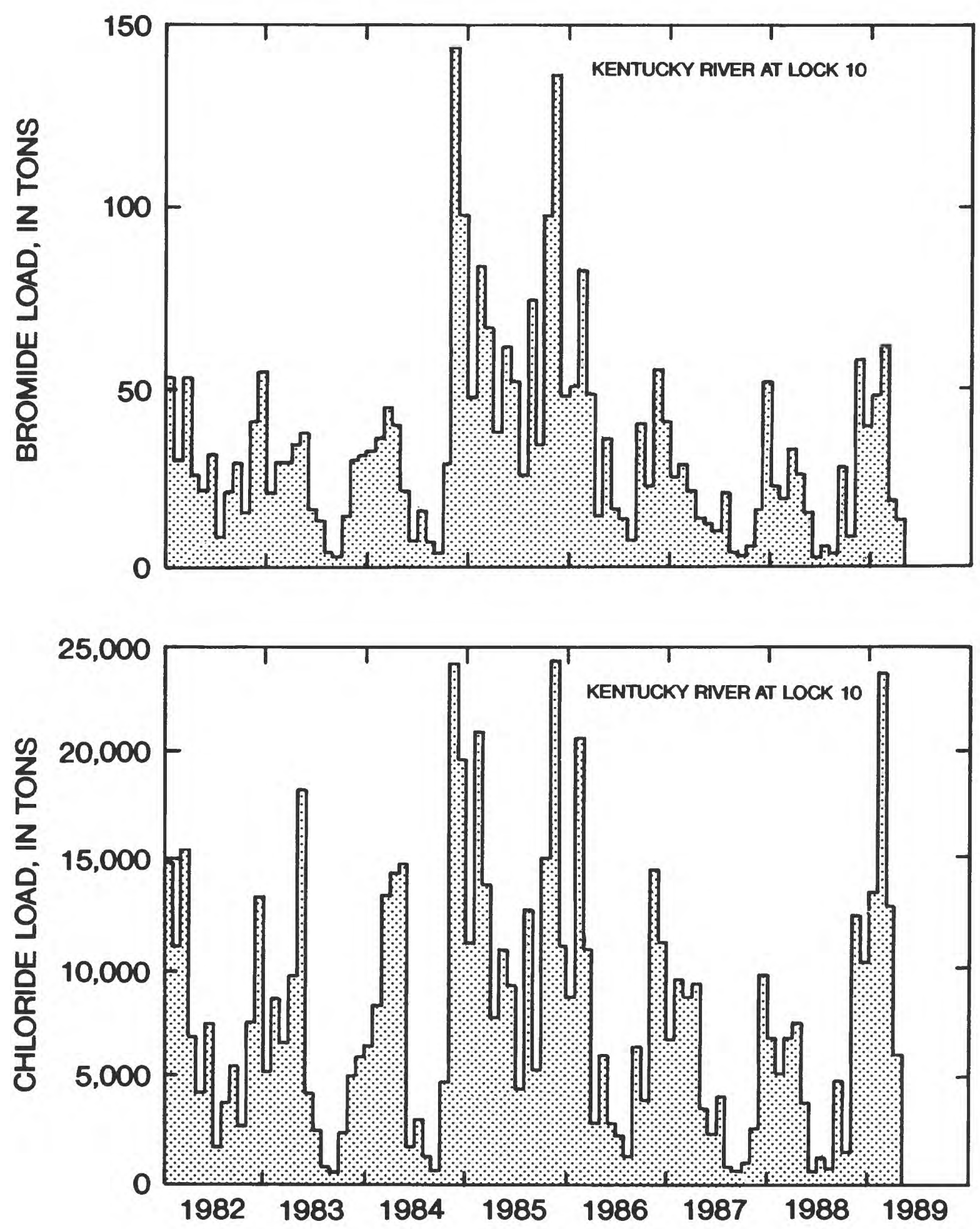

Figure 18.--Monthly dissolved bromide and chloride load of the Kentucky River at Lock 10, January 1982 to March 1989. 


\section{RELATION OF OIL PRODUCTION TO CONSTITUENT TRANSPORT}

Greatest monthly chloride transport in the Kentucky River at Lock 10 during 1982-88 was 24,400 tons which occurred in November 1985, just one month after peak oil production during the period. Because the large chloride and bromide loads of the Kentucky River at Lock 10 seem to be due to drainage from oil-production areas, attempts were made to relate oll-production levels to constituent transport in the Kentucky River. Several problems complicate the development of such a relation:

- The amount of water produced or discharged for each barrel of oil produced can vary greatly between wells;

- Some oll producers use injection wells for disposal of brines;

- Concentrations of dissolved constituents in brines may vary from site to site; and

- The oil production records are based on time of delivery and not on actual time of production.

There appears to be a positive correlation between oil production in the Kentucky River basin and bromide load in the Kentucky River at Lock 10, based on comparison of data for six annual May through April periods as shown in figure 19. However, even though the regression equation accounts for 89 percent of the variability with a probability value less than 0.01 , the data are grouped as only three data points, which makes the relation statistically tentative. May was selected as the beginning of the annual comparison periods because constituent transport during the high-flow winter months was assumed to flush the system.

This positive correlation suggests a strong relation between production of oil and gas and dissolved constituent loads in streams. However, additional information is needed on oil and gas production activities to further refine and quantify this relation. Most important is consistent and comparable information on oil and gas production activities for individual flelds or aggregate information linked to specific hydrologic units. The type of information that are needed include: (1) accurate locations of ofl and gas production wells, brine injection wells, and facilities such as storage tanks or oil/brine separators; (2) monthly oil and gas production estimates; (3) existence and location of brine and other effluent discharges; (4) effluent water-quality data; (5) monthly average effluent flow rates; (6) descriptions of programs for assuring the quality of effluent water-quality and flow rate data; and (7) descriptions of current, past or planned effluent treatment technologies.

Although some of the above mentioned data are already supplied to the state by the oil and gas industry, much of it is not available or suitable for use in water-quality assessments. For example, records of oil and gas production volumes are provided to the state for tax purposes, but these are classified as proprietary information. Also, Kentucky Division of Water's Oil 


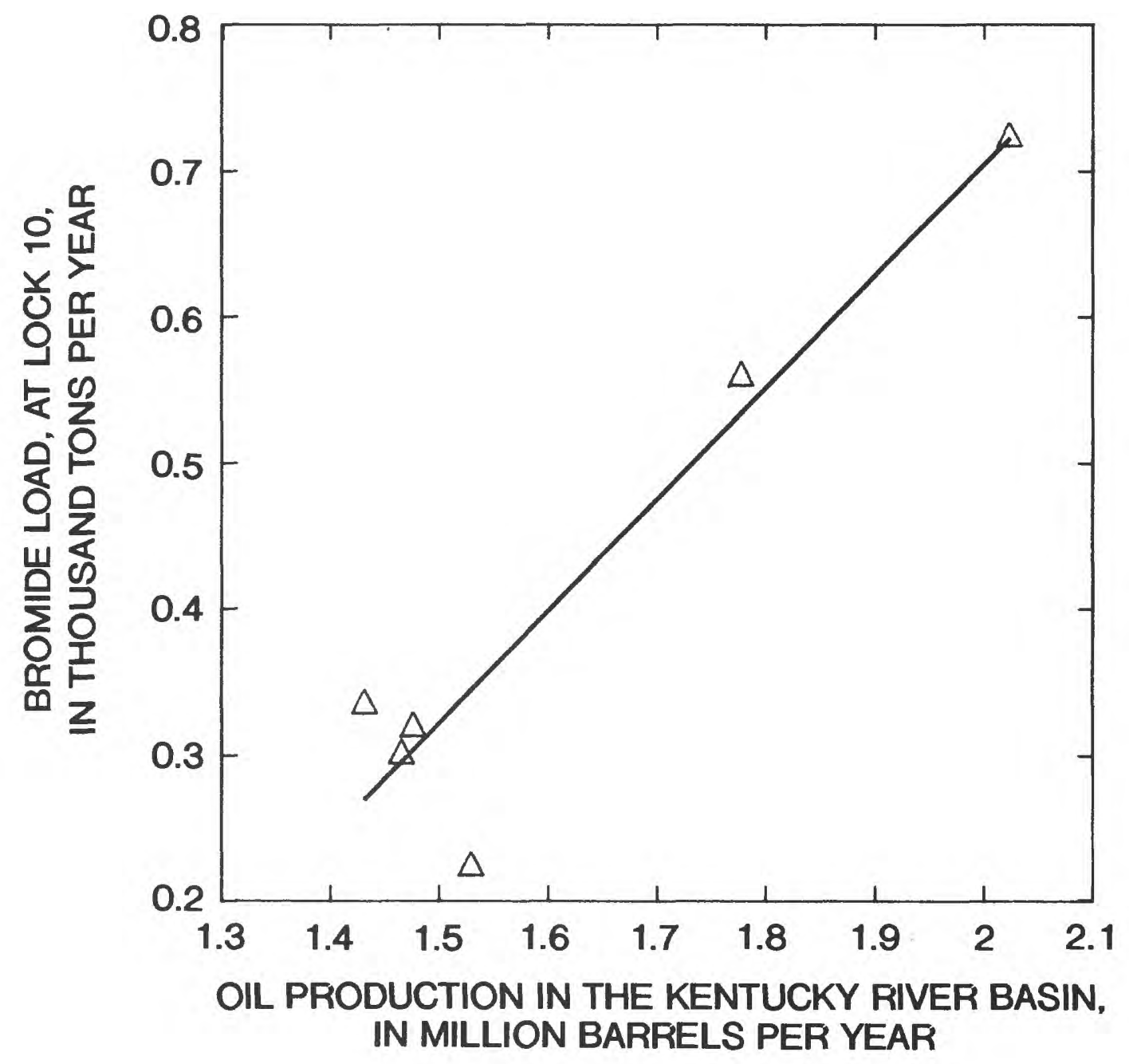

Figure 19.--Relation of oil production in the Kentucky River basin to the dissolved bromide load in the Kentucky River at Lock 10, May 1983 to April 1988. 
and Wet Gas Well Registry Lease files do not contain machine readable location information for many oil and gas wells or facilities. These state files contain information on the amount of brine produced per barrel of oil and the method of brine disposal for each permitted oil we11, but because data on the amount of production from individual wells is proprietary, brine discharge estimates can not be calculated.

Concentrations of dissolved constituents in oil-production brines are highly variable from well to well due to differences in the geologic character of the source formations or due to differences in the amount of dilution from freshwater injection for secondary oil recovery. Even if the volume of brine discharges from individual wells were known, accurate load calculations could not be performed without information on the constituent concentrations of the brine from each well.

The permit, compliance, and enforcement system that is now in existence does not provide the information needed to adequately assess water-quality conditions and provide insights toward cause and effect. Brine discharge and chemical characteristics should be routinely monitored and made available for use in a variety of ecological evaluations.

\section{SUMMARY}

The Kentucky River basin is the most densely populated river basin in Kentucky and surface water from the Kentucky River, its tributaries, and reservoirs provide more than 95 percent of the public water supplied in the basin. Because production of oil is a major activity in parts of the basin, a study was conducted to describe the chemical character of ground and surface water in the oil fields, and to assess the effects of drainage from these fields on downstream water quality.

The oil-producing units in the study area occur in what is commonly known as the "Corniferous zone", which corresponds to the Middle Devonian Boyle Dolomite and the Middle Silurian Bisher (?) Limestone. Oil production occurs mainly from stripper wells, which are defined as those which produce less than 10 barrels of oil per day. About 10 barrels of brine are produced along with each barrel of oil produced. Discharge of this brine to streams, and injection of fresh water or a mixture of fresh water and brine into the oilproduction units for enhanced oil recovery are common practices. Discharge of brine from oil separators is suspected as a major source of dissolved constituents to streams draining oil-production areas. Water sampled from four oil separators draining to streams during September 1988 contained dissolved solids in excess of $10,000 \mathrm{mg} / \mathrm{L}$.

Ground-water sampling in the Furnace Fork oil-production watershed indicated that (1) water from shallow alluvial aquifers probably was not widely affected by oil-production activities, (2) water flooding has decreased the dissolved-solids content in water from the "Corniferous zone" but not in the overlaying New Albany Shale, and (3) the character of water in the Borden Formation may reflect mixing of freshwater and saline water from deeper rock units. Vertical ground-water flow potential seems to be primarily to the basal part of the Borden Formation from units both above and below. Water 
from the shallow bedrock springs and dug wells in the alluvium is usually of the calcium bicarbonate type, and water from deep we1ls, including oilproduction water, is of the sodium chloride type.

Surface water from a non-oil-production watershed was a calciumbicarbonate type except about 10 percent of the time when specific conductance was high and chloride became the dominant anion. Calcium and carbonates (carbonate plus bicarbonate) were the predominant dissolved constituents transported from the non-production watershed, chloride was less than 5 percent of the annual dissolved constituent transport, and bromide was less than 0.01 percent. Non-production watershed yields of bromide and chloride for the period April 1987 through March 1989 were 0.08 and 19 tons $/ \mathrm{mi}^{2}$, respectively.

0il-production activities were the source of many dissolved constituents in water from Big Sinking Creek and Furnace Fork; among these constituents were barium, boron, bromide, chloride, magnesium, sodium, and strontium. These constituents were observed in greatest concentrations in Big Sinking Creek, which drains a watershed containing several facilities permitted to discharge oil-brine to streams. The lowest concentrations of these constituents were observed in Cat Creek which drains a watershed where oil is not produced. Chloride concentrations in Furnace Fork exceeded the Kentucky criteria of $600 \mathrm{mg} / \mathrm{L}$ for protection of aquatic habitats about 3 percent of the time. However, chloride concentrations in Big Sinking Creek exceeded the 600 $\mathrm{mg} / \mathrm{L}$ criteria more than 40 percent of the time. Concentrations of organic substances in waters of the oil-production watersheds and non-production watershed were similar.

The release of oil-production brines in a watershed can convert the natural calcium bicarbonate type water to one of the sodium chloride type. Water from the Big Sinking Creek oil-production watershed was a sodiumchloride type throughout the study period, and bromide in excess of 0.3 percent of total anions was present about 80 percent of the time. Less oil production occurs in the Furnace Fork watershed than in the Big Sinking Creek watershed and the type water in Furnace Fork varies from a calcium-bicarbonate type like that of Cat Creek to a sodium chloride type resembling that of Big Sinking Creek. Furnace Fork water was similar to that of Cat Creek when values of specific conductance were small (less than $600 \mu \mathrm{S} / \mathrm{cm}$ ), but similar to water of Big Sinking Creek when specific conductance values were large (greater than $1,300 \mu \mathrm{S} / \mathrm{cm}$ ).

Dissolved constituent transport from the oil-production watersheds and the non-production watershed had a similar non-uniform loading pattern, which indicates intermittent release. In the oil-production watersheds this may be due to water that is temporarily stored in the alluvium or shallow bedrock. Assuming that oil production is relatively constant, transport pulses include accumulated inputs from production activities over extended periods, and are a function of both stream discharge and time since the system was last flushed. Comparatively little constituent transport occurs during low flows in summer and fall even though constituent concentrations are greatest at that time. During high flows the opposite occurs. That is, the concentrations are small but the loads are large. The greatest transport usually occurs during initial high-flow storm events following the low-flow season. 
The average annual yields of bromide, chloride, sodium, and strontium in the Big Sinking Creek watershed were at least 10 times greater than from the non-oil-production Cat Creek watershed. The average daily chloride loads of Furnace Fork and Big Sinking Creek were much larger than that allowed by State permits for discharge of oil-production brines to streams. The average nonnatural chloride load of Big Sinking Creek was approximately 34,000 pounds per day, but a total chloride discharge of only slightly more than 2,000 pounds per day is permitted in the watershed. The average non-natural chloride load of Furnace Fork was approximately 1,600 pounds per day, but a chloride discharge of only 12 pounds per day is permitted in the watershed.

The areal extent of oil-brine discharges included streams tributary to the North and South Forks of the Kentucky River, the headwaters of Millers Creek, and many streams tributary to the Middle and South Forks of the Red River. Oil-production watersheds contribute a large percentage of the dissolved constituent loads of the Kentucky River. Concentrations of barium, bromide, chloride, sodium, and strontium in the main stem of the Kentucky River were determined to increase downstream of river mile 270 due to drainage from oil-production areas. During the period April 1987 to March 1989, the average annual chloride and bromide loads in the Kentucky River at Lock 10 were approximately 72,600 tons and 265 tons, respectively. The two oilproduction watersheds studied, which drain only 0.84 percent of the drainage area upstrean from Lock 10 , contributed 10.3 percent of the chloride load and 22.5 percent of the bromide load at Lock 10 .

The largest concentrations of chloride and bromide in the Kentucky River at Lock 10 typically occur in the fall during the first period of significantly increased runoff following the dry late summer months. This period corresponds in general to the time of the first flushing of accumulated salts from the watersheds studied. In addition, monthly transport of chloride and bromide in the Kentucky River at Lock 10 had a non-uniform pattern similar to that of the watersheds studied. Largest monthly chloride transport during 1982-88 was 24,400 tons which occurred in November 1985 just one month after peak oil production during the period.

There appears to be a positive correlation between oil production in the Kentucky River basin and bromide load in the Kentucky River downstream of the oil and gas production areas of the basin. This positive correlation suggests a strong relation between production of oil and gas and dissolved constituent loads in streams. However, additional information is needed on oil and gas production activities to further refine and quantify this relation. Most important is consistent and comparable information on oil and gas production activities for individual fields or aggregate information linked to specific hydrologic units. Although some of the needed data are already supplied to the state by the oil and gas industry, much of it is not available for use in water-quality assessments.

The permit, compliance, and enforcement system that is now in existence does not provide the information needed to adequately assess water-quality conditions and provide insights toward cause and effect. Brine discharge and chemical characteristics should be routinely monitored and made available for use in a variety of ecological evaluations. 


\section{REFERENCES}

Black, D.F.B., 1978, Geologic map of the Zachariah quadrangle, east-central Kentucky: U.S. Geological Survey Geological Quadrangle Map GQ-1452, scale $1: 24,000,1$ sheet.

Bradfield, A.D., and Porter, S.D., 1990, Summary of biological investigations relating to surface-water quality in the Kentucky River basin, Kentucky: U.S. Geological Survey Water-Resources Investigations Report $90-4051,63 \mathrm{p}$.

Feneman, N.M., 1938, Physiography of the United States: New York, N.Y., McGraw-Hill Book Company, Inc., 714 p.

Freeman, L.B., 1951, [repr. 1959], Regional aspects of Silurian and Devonian stratigraphy in Kentucky: Lexington, Ky., Kentucky Geological Survey, Ser. 9, Bul1. 6, 575 p.

Garcia, R., Sholar, C.J., and Toms, S.G., 1988, Water resources Kentucky water year 1988: U.S. Geological Survey Water-Data Report KY-88-1, 569 p.

-..-1989, Water resources Kentucky water year 1989: U.S. Geological Survey Water-Data Report KY-89-1, 464 p.

Hal1, F.R., and Palmquist, W.N., Jr., 1960, Availability of ground water in Clark, Esti11, Madison, and Powel1 Counties, Kentucky: U.S. Geological Survey Hydrological Investigations Atlas HA-19, scale $1: 125,000,3$ sheets.

Haney, D.C., 1976, Geologic Map of the Cobhill quadrangle, east-central Kentucky: U.S. Geological Survey Geological Quadrangle Map GQ-1347, scale $1: 24,000,1$ sheet.

Hoge, H.P., Wigley, P.B., and Shaw, F.R., 1976, Geologic map of the Irvine quadrangle, Estill County, Kentucky: U.S. Geological Survey Geological Quadrangle Map GQ-1285, scale 1:24,000, 1 sheet.

Hopkins, H.T., 1966, Fresh-saline water interface map of Kentucky: Kentucky Geological Survey, Ser. 10., scale 1:500,000, 1 sheet.

Johnson, J.H., Stapleton, J.M., and McGrain, P., compilers, 1962, Mineral resources and mineral industries of Kentucky: Kentucky Department of Commerce, scale 1:500,000, 1 sheet.

Kentucky Natural Resources and Environmental Protection Cabinet, Division of Water, 1984, Kentucky Report to Congress on water quality, 1984-85: Frankfort, Kentucky, 159 p.

-.-1986, Kentucky Report to Congress on water quality, 1986: Frankfort, Kentucky, 192 p.

-.-1988, Kentucky Report to Congress on water quality, 1988: Frankfort, Kentucky, 155 p.

-.-1990, Surface water standards, Kentucky Administrative Regulations, Title 401, Chapter 5, Section 31: Frankfort, Kentucky, 14 p.

Krieger, R.A., and Hendrickson, G.E., 1960, Effects of Greensburg Oilfield brines on the streams, wells, and springs of the upper Green River basin, Kentucky: Kentucky Geological Survey, Ser. 10, Repr. no. 2, 36 p.

Logan, R.W., Beck, G.V., Cal1, S.M., Houp, R.E., Metzmeier, L., Mil1s, M.R., Roth, C.A., Schneider, C.C., Walker, D.K., and Westerman, A., 1989, Millers Creek drainage biological and water quality investigation for stream use designation: Kentucky Natural Resources and Environmental Protection Cabinet, Division of Water Technical Report No. 25, 93 p. 
McDowe11, R.C., 1981, Correlation chart for units on the geologic map of Kentucky: U.S. Geological Survey Miscellaneous Field Studies Map, MF-1291, 1 sheet.

McGrain, Preston, 1958, Summary of secondary recovery operations in Kentucky in 1957: Kentucky Geological Survey, Ser. 9, Repr. no. 17, 43 p.

Pope, L.M., Arruda, J.A., and Fromm, C.H., 1988, Relation of trihalomethaneformation potential to water-quality and physical characteristics of small water-supply lakes, eastern Kansas: U.S. Geological Survey WaterResources Investigations Report 88-4161, 46 p.

Price, W.E., Jr., Kilburn, Chabot, and Mull, D.S., 1962, Availability of ground water in Boyd, Carter, Elliott, Greenup, Johnson, Lawrence, Lee, Menifee, Morgan, and Wolfe Counties, Kentucky: U.S. Geological Survey Hydrological Investigations Atlas HA-37, scale 1:250,000,3 sheets.

Price, W.E., Jr., Mu11, D.S., and Kilburn, Chabot, 1962, Reconnaissance of ground-water resources in the Eastern Coal Field region, Kentucky: U.S. Geological Survey Water-Supply Paper 1607, 56 p.

Robinson, L.C., 1927, Map of the areal and structural geology of Wolfe County, Kentucky: Kentucky Geological Survey, Ser. 6.

Sholar, C.J., 1988, Water use in Kentucky, 1985, with emphasis on the Kentucky River basin in Proceedings from Symposium on Water-use data for Water Resources Management: Bethesda, Maryland, American Water Resources Association, p. 85-92.

Sholar, C.J., and Lee, V.D., 1988, Water use in Kentucky, 1985: U.S. Geological Survey Water-Resources Investigations Report 88-4043, 53 p.

Smoot, J.L., Liebermann, T.D., Evaldi, R.D., and White, K.D., 1990, Surface water-quality assessment of the Kentucky River basin, Kentucky: Analysis of available water-quality data through 1986: U.S. Geological Survey Open-File Report 90-360, 209 p.

Stack, W., 1965, Some aspects of water flooding in the Big Sinking Field, Lee County, Kentucky: Kentucky Geological Survey, Ser. 10, Special Publication 10, p. 70-93.

Steel, R.G., and Torrie, J.H., 1980, Principles and procedures of statistics (2d ed.): New York, N.Y., McGraw-Hill Book Company, 633 p.

U.S. Department of Commerce, 1982, 1980 census of population, number of inhabitants, Kentucky: Bureau of the Census, PC80-1-A19, 53 p.

U.S. Environmental Protection Agency, 1983, The stripper we11s of East-Central Kentucky - an environmental assessment: Prepared by SMC Martin Inc., U.S. Environment Protection Agency, Region IV, Ref: 8412-040-94005, 86 p.

-.-1990a, Secondary maximum contaminant levels (section 143.3 of part 143, National secondary drinking water regulations): U.S. Code of Federal Regulations, Title 40, Parts 100 to 149 , revised as of July 1 , 1990 , p. 674 .

-..-1990b, Maximum contaminant levels (subpart B of part 141, National primary drinking water regulations): U.S. Code of Federal Regulations, Title 40, Parts 100 to 149, revised as of July 1, 1990, p. 559-563.

Viessman, W., Jr., and Hammer, M.J., 1985, Water supply and pollution control: New York, N.Y., Harper \& Row, p. 227.

Weir, G.W., 1974, Geologic map of the Stanton Quadrangle, Powel1 and Estill Counties, Kentucky: U.S. Geological Survey Geological Quadrangle Map GQ-1182.

Wilson, E.N., and Sutton, D.G., 1973, Oil and gas map of Kentucky: Kentucky Geological Survey, series 10 , scale $1: 250,000,4$ sheets. 